\title{
PHYTHOGEOGRAPHIC ANALYSIS OF SLOVENIA FITOGEOGRAFSKA OZNAKA SLOVENIJE
}

\author{
Mitja ZUPANČIČ́ ${ }^{1}$ \& Branko VREŠ ${ }^{2}$
}

http://dx.doi.org/10.3986/fbg0048

\begin{abstract}
Phythogeographic analysis of Slovenia

On the basis of the flora and vegetation and phytogeographical areas of Slovenia, we wanted to determine as objectively as possible the distribution of plant provinces, with an emphasis on the Illyrian province, which is characteristic of Slovenian territory. In the phytogeographical analysis of Slovenia we defined a new, pre-Noricum-Slovenian floral province. Five floral provinces in Slovenia are thus now known: Alpine province of the Alpine-High-Nordic region and Central European, Illyrian, Illyrian-Adriatic and PreNoricum-Slovenian floral provinces of the Euro-SiberianNorth American region.
\end{abstract}

Key words: flora, vegetation, phytogeography, Slovenia

\section{IZVLEČEK}

\section{Fitogeografska oznaka Slovenije}

$\mathrm{Na}$ osnovi flore in vegetacije ter fitogeografskih območij Slovenije smo želeli čimbolj objektivno opredeliti razširjenost rastlinskih provinc s poudarkom na ilirski provinci, ki je značilna za slovensko ozemlje. Pri fitogeografski analizi Slovenije smo izdvojili (opredelili) novo, prenorijsko-slovensko rastlinsko provinco. Tako je v Sloveniji zdaj znanih pet rastlinskih provinc, in sicer: alpska provinca alpsko-visokonordijske regije ter srednjeevropska, ilirska, ilirsko-jadranska in prenorijsko-slovenska rastlinska provinca evrosibirsko-severnoameriške regije.

Ključne besede: flora, vegetacija, fitogeografija, Slovenija

\footnotetext{
${ }^{1}$ SAZU, Novi trg 3, SI-1000 Ljubljana, Slovenija

${ }^{2}$ ZRC SAZU, Novi trg 2, SI-1000 Ljubljana, Slovenija, branevr@zrc-sazu.si
} 


\section{INTRODUCTION}

In 1969, M. Wraber (1969) developed a phytogeographical division of Slovenia into six areas, on the basis of the then knowledge of forest vegetation: Alpine, pre-Alpine, Dinaric, pre-Dinaric, sub-Mediterranean and sub-Pannonian phytogeographical areas. With new knowledge of the vegetation of Slovenia and consideration of the flora, the phytogeographical regions were subdivided into lower units - districts, and the boundaries or delimitation between the areas were supplemented or adjusted, especially between the Alpine and pre- Alpine areas. At the same time, the authors' desire was to set these phytogeographical units in the appropriate, standardly valid plant provinces, which was also done (Zupančič et al., 1987).

In connection with the occurrence of flora, or individual species, that are exclusively or mostly present in a particular phytogeographical area and in a particular district, we wanted to confirm the correctness of the delimitation or boundaries of a particular area or district. Based on maps of species distribution in the Materials for the Atlas of flora of Slovenia (JogAn et al., 2001) and data from the FloVegSi database (T. SELIŠKar et al., 2003), in a simplified way with a lattice of phytogeographical areas and districts using selected/defined diagnostic species, we established exclusive or mostly present flora for an individual phytogeographical area or subordinate phytogeographical unit (district). Diagnostic species were defined as: (i) exclusively or predominantly present species (such that occur exclusively in only one area); and (ii) mainly present species (such as those that are mainly widespread in only one region and only a few individual sites in a few other areas). The simple way of determining the presence of flora is merely relative, with certain deviations, such as in the frequency of a taxon quantitatively undefined on the map of distribution of species, subspecies, varieties: the sign of presence of a species in a quadrant may mean the occurence/presence of one or more sites of the species, or the occurrence of multiple instances of the plant or only one individual. Nevertheless, the information is sufficiently clear and useful. In addition to taking into account the currently known Slovenian distribution of a taxon, we used its broader (terrestrial) chorological affiliation (geoelement, floral element) and biological form. These elements show the biological and ecological conditions in relation to the living conditions in which the plant thrives.

The discussion is divided into two chapters. In the first chapter, we determine the frequency of plant species in phytogeographical areas or districts, which is the basis for the second chapter on the division of Slovenia into floral provinces. In addition to the flora, vegetation and the existing phytogeographical division of Slovenia, we also took into account the publications of the most relevant botanists - phytogeographers from the earlier period, whose work is directly or indirectly related to Slovenia, such as: AdAmović (1906), BeCK (1907, 1908, 1913), НАYeK (1907, 1923); Horvat (1954, 1962), Horvatić (1957, 1963), Mayer $(1946,1950,1951$, 1952, 1953, 1960), Meusel et al. (1965), M. Wraber (1969), Soó (1961), POCS (1960), Karpati (1966). We also took into account the work of botanists and phytogeographers from recent decades, such as Nada Praprotnik (1987), Trinajstić (1976, 1986, 1995), ŠUgAR (1984, 1995 with colleagues), MARINČEK (1994), Košır (1975) and Zupančıč and colleagues (1987, 1995).

The first coordinating works for defining and connecting phytogeographical areas with standard plant provinces were already established in the nineties of the last century (Zupančič et al., 1987, 1995). We have devoted ourselves thoroughly to the problem in the present discussion.

The first reconciliation of WraBeR's (1969) phytogeographical regions with standard plant provinces was based primarily on forest or potential natural vegetation, and it had a more modest floristic basis (Zupančič et al., 1987). We encountered great difficulties in this reconciliation, especially in defining and delineating in the transalpine region of north-eastern Slovenia (Prekmurje, Prlekija), where a special DravaMura district was envisaged. In addition, at that time we were convinced that four regions were represented in Slovenia: in addition to the Euro-Siberian-North American and Alpine-High-Nordic, the Mediterranean and Pannonian-Pontic regions. In the last analysis (ŠUGAR et al., 1995), it appeared that the last two regions do not exist in Slovenia, because we are unable to identify appropriate diagnostic species for them or they do not exist at all (e.g., for the Pannonian-Pontic region). We found out that Mediterranean evergreen vegetation and flora is fragmentarily present on only few square meters at Osp, Stena nad Dragonjo and on the Strunjan cliff. This discussion gives greater stress to the floral basis, i.e., the distribution of species and findings of older authors - phytogeographers (Adamović, Beck, Hayek, etc.). Our aim is to show, as realistically as possible, in connection with natural geographical features, the phytogeographical division of Slovenia into plant provinces. In particular, we were interested in the extent of the Illyrian floral province, 
which is a speciality of our country: it stretches from the southeast of the Balkan Peninsula and ends more or less here, or even slightly towards the northeast.

Today, 32 districts are recognised in Slovenia, in six phytogeographical areas, and five plant provinces in two floral regions. The occurrence of the fifth province - pre-Noricum-Slovenian - is foreseen for the territory of northeastern Slovenia and will be distinguished (delimited) from the Central European province.

\section{FREQUENCY AND OCCURENCE OF PLANT SPECIES IN PHYTOGEOGRAPHIC AREAS OF SLOVENIA}

Slovenia is divided into 6 phytogeographic areas: Alpine, pre-Alpine, Dinaric, pre-Dinaric, sub-Mediterranean and sub-Pannonian (M. Wraber 1969). An upgrading of the phytogeographic areas of Slovenia determined lower phytogeographic units, such as provinces, sectors, subsectors and the lowest unit, districts (Zupančič et al. 1987, Zupančič \& ŽaGar 1995). We were interested in how many plant species with subspecies grow exclusively in a single phytogeographic area or in individual districts of one or another phytogeographic area.

From 3192 (Jogan et al. 2001) to around 3450 taxons or even more (T. SElišKar et al. 2003, MARTINČič et al. 2007) are recorded today in Slovenia. This takes into account all taxons, not just autochthonous species. For this kind of research, we used the published list of plant species of JogAn et al. (2001), which is already somewhat obsolete, in terms of both number and nomenclature of taxons. In relation to the actual designation of taxons, we used the most recent plant key (MARTinčič et al. 2007) and the computer program FloVegSi (T. SelišKar et al. 2003).

Each phytogeographic area has some special plant species that only thrive in that specific phytogeographic area. The aforementioned settlement of a specific plant in only one phytogeographic area conditions its phytogeographic distribution, together with specific ecological conditions, such as climate or mezzo- and microclimate, geological base, relief, exposure, altitude, morphology of the terrain, soil, as well as anthropological influences and more. Research has shown that the sub-Mediterranean and Alpine phytogeographical areas are floristically richest. The cause is probably the pronounced climatic and geological-morphological conditions. In the Alpine phytogeographic area, it is cold, fairly damp, with an alpine-continental climate with varied orographic and relief forms. The sub-Mediterranean phytogeographic area is warm, less moist, humidity is present above all in autumn and partially spring, and there are often summer droughts with occasional extreme high temperatures. It is a hilly world, although the relief is richly broken. Carbonate and sili- cate geological bases alternate in both phytogeographic areas. One would expect numerous plant particularities in the sub-Pannonian area but it is already known from floristic research that the region is impoverished with Pannonian-Pontic species. There is no explicit subPannonian, let alone Pannonian continental climate in Slovenia. We are only on the edge of the sub-Pannonian phytogeographic area, which is not settled by explicitly Pannonian-Pontic species. The Slovene Dinaric and pre-Dinaric areas are particularities on a European scale. They extend from the southeast to the northwest, from the Kolpa to the Soča above the sub-Mediterranean area. The Dinaric area is orographically varied, for the most part carbonate, damp under the influence of an Atlantic climate. The pre-Dinaric area is similarly for the most part carbonate, hilly, with a continental climate. The areas are floristically rich, full of DinaricBalkan floristic particularities. Both areas have few species that grow (thrive) exclusively in the Dinaric or pre-Dinaric phytogeographic area. One cause is the interweaving of Dinaric-Balkan or southeast EuropeanIllyrian species between the two phytogeographic areas.

There are a great many fewer plant species that thrive exclusively in districts. There are simply no such species in some districts, e.g., in few districts of the pre-Dinaric phytogeographic area, where there are none of them in three of eight districts, or in the Alpine area, where there are very few in three of nine districts or in the Dinaric area where there are none in one of four districts. Districts in other phytogeographic areas are more or less rich with their own plant species. The floristically richest are the Koper-Šavrinija (180), Ptuj (Drava-Mura) (58), Karst-Vipava (57), Kranjska (48) and Štajerska-Koroška (37) districts.

What does the number of species in individual phytogeographic areas or in their districts mean?

The richness of flora in individual phytogeographic areas or in their districts certainly means or confirms that these phytogeographic units are justified and well 
chosen; it indicates their floristic and ecological particularity. These species can be classified among diagnostically important species or even among characteristic or distinguishing species, as a supplement to already chosen or established characteristic species of a particular phytogeographic area. The Alpine phytogeographic area is recognised by its particular cryophilous species, such as the endemics Campanula $x$ vrtacensis, P. alpinum subsp. victoris, Nigritella kossutensis and $N$. ravnikii or sub-endemics, e.g., A. tauricum subsp. hayekianum, A. tauricum subsp. tauricum, A. tauricum subsp. latemarense, Campanula zoysii, Cerastium julicum, Festuca calva, F. laxa, Gentiana froelichii, Heracleum austriacum subsp. siifolium, Leucanthemum lithopolitanicum, Nigritella lithopolitanica, $N$. widderi, N. archiducis-joannis, Papaver alpinum subsp. ernesti-mayeri, Pedicularis elongata subsp. julica, Saxifraga hohenwartii, Scorzoneroides crocea etc.

The sub-Mediterranean area is marked by thermophilous sub-Mediterranean and Mediterranean species, which are not found in other phytogeographic areas, e.g., Asparagus maritimus, Cistus salviifolius, Colutea arborescens, Coronilla cretica, Euphrasia marchesettii, Osyris alba, Rubia peregrina, Smilax aspera, Viburnum tinus, or some quite rare woody species in Slovenia, such as: Celtis australis, Pistacia terebinthus and Quercus ilex. In addition to the enumerated species, some (sub)endemics also appear in the sub-Mediterranean region, namely: Alyssum montanum subsp. montanum, Campunula marchesettii, Hieracium dragicola, Knautia drymeia subsp. tergestina, Moehringia tommasinii, Ranunculus pospichalii etc.

The Dinaric phytogeographic area is floristically rich but modest in terms of particularities or species growing exclusively or predominantly in this area. Four Slovene endemics thrive here: Hladnikia pastinacifolia, Primula carniolica with the hybrid Primula $\mathrm{x}$ venusta and Ranunculus wraberi. Dinaric-Balkan species that occur exclusively in the Dinaric area arrived here from the southeast, namely: Cerastium dinaricum, Edraianthus graminifolius, Festuca bosniaca, Helianthemum rupifragum, Polygala croatica, Thymus balcanus, which, with the endemics, excellently define the Slovene Dinaric phytogeographic area.

The sub-Pannonian phytogeographic area, which is on the extreme westerly sub-Pannonian rim, does not have explicitly Pannonian-Pontic species. The majority of these are generally widespread species of the Pannonian region but which do not reach our other phytogeographic areas, namely: Daphne cneorum subsp. arbusculoides, Epipactis nordeniorum, Gagea spathacea, Moenchia mantica subsp. caerulea, Myosotis laxa, Papaver dubium, Potentilla supina, Pulmonaria mollis, Pulsatilla grandis, Veronica triphyllos, Viscum laxum etc. In the Slovene sub-Pannonian phytogeographic area some generally widespread species occur more frequently and in larger numbers than in other phytogeographic areas of Slovenia, whereby they give a particular seal to the Slovene sub-Pannonian area, namely: Chenopodium rubrum, Cynosorus echinatus, Epipactis voethii, Omphalodes scorpioides, Scirpus radicans, Trifolium pannonicum etc.

The River Mura and its tributaries have created oxbows, backwaters, standing water; in places artificial lakes have been formed by the abandonment of gravel pits, or fishponds have been created, individual ones of which have been abandoned. A special riverine, swamp or wetland flora has developed on these water surfaces, typical of the Slovene sub-Pannonian phytogeographic area. Such plants include: Cyperus michelianus, Montia fontana, Marsilea quadrifolia, Nymphoides peltata, Potamogeton obtusifolius, Typha minima, Stratiotes aloides, Wolffia arrhiza. Some species also occur elsewhere in ecologically similar wetland habitats, in other phytogeographic areas, although they are frequent and more constant in the sub-Pannonian region: Cyperus glomeratus, Lemna trisulca, Scirpus radicans, Typha laxmanii etc. All the enumerated species can be considered more or less diagnostic species of the Slovene sub-Pannonian phytogeographic area.

The pre-Alpine phytogeographic area is not as rich as the Alpine area in plant species that thrive exclusively in it. Only some interesting plants are present, including the endemics Leontodon berinii, Moehringia villosa, Ranunculus thora f. pseudoscutatus, R. aesotinus and Saxifraga paradoxa and the protected species Gladiolus imbricatus, Daphne cneorum subsp. cneorum, Liparis loeselii, Lycopodiella inundata etc. In addition to the enumerated, the following species are interesting: Cirsium waldsteinii, Diphasiastrum alpinum, Euphorbia triflora subsp. kerneri, Poa carniolica, Primula veris subsp. canescens, Woodsia ilvensis, which are more or less reliably ranked among diagnostically important species of the Slovene pre-Alpine phytogeographic region. The majority of the enumerated species arrive here from the west. One could probably find some other interesting and rare species that mark the Slovene pre-Alpine region.

The pre-Dinaric phytogeographic area is the poorest in exclusive plant species, although it is floristically rich. A smaller selection of flora nevertheless marks this phytogeographic area, despite the fact that some of the mentioned species individually thrive in the Dinaric, sub-Mediterranean or even pre-Alpine phytogeographic areas. Constant, growing exclusively or mainly in the pre-Dinaric phytogeographic area, are: 
Acer obtusatum, Aconitum variegatum subsp. nasutum, A. vitosanum, Asplenium trichomanes subsp. pachyrhachis, Dianthus giganteus subsp. croaticus, Erysimum carniolicum, Fumaria officinalis subsp. wirtgenii, and Rosa blondaeana.

The majority of the districts of the phytogeographic areas have their own growing species, as is evident from Tables 1 and 2. However, some districts do not have them or very few of them: such as the Southeast Alps district and Primorje-Julian Alps district in the Alpine phytogeographic region, KrimMokrica-Gotenica district in the Dinaric phytogeographic area and West Dolenjska, Notranjsko, Polhov gradec, Ig, Bohor-Kum and Central Dolenjska districts in the pre-Dinaric phytogeographic area. However, species from other phytogeographic areas have arrived in these districts, which one would not expect here. They thus give these districts a specific floristic and ecological seal or difference that justifies their existence. A clear example is the Ig district, in which there are some Alpine and numerous Dinaric species. Alpine species characterise the particularity of the district. Because of the presence of Dinaric species, it is not clear whether to rank it into the pre-Dinaric (ZupančIČ \& ŽAGAR 1995) or Dinaric phytogeographic area, in which Accetto (2010) places it.

For phytogeographical areas and districts, we analysed plant species that exclusively or mainly thrive in a specific phytogeographical area and defined them according to biological forms and their phytogeographical distribution (by geoelements). This is shown in Tables 3-20. The selected plant species thus reflect a particular floral and ecological image of a particular district, and the group of flora of the districts in a certain phytogeographical area consequently shows its floral and ecological appearance (Tables 21-24). For the definition of biological forms and geoelements, we used the following literature: Pignatti (2005), in part Aeschimann et al. (2004) and to a lesser extent PoLDINI (1991).

The analysis of exclusively or mainly present species in the Alpine phytogeographical area (Tables 3, 4

Table 1: Number of exclusively or mainly present species in phytogeographic areas Tabela 1: Število vrst izključno ali večinoma prisotnih na fitogeografskih območjih

PHYTOGEOGRAPHIC AREA

Fitogeogr. območje

NUMBER OF SPECIES

in all districts/

$\mathrm{v}$ vseh distriktih

in individual districts /

v posameznih distriktih

Predominantly in a phytogeographic area / pretežno na fitogeogr. območju

In all phytogeographic areas / na vsem fitogeografskem območju

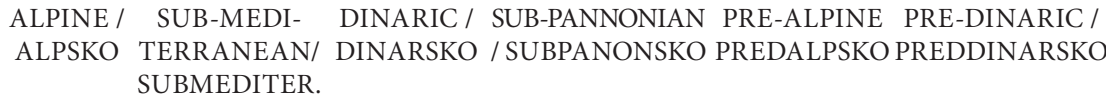
SUBMEDITER.

Table 2: Number of species bound exclusively or mainly to an individual district Tabela 2: Število vrst, ki so vezane izključno ali večinoma na posamezen distrikt

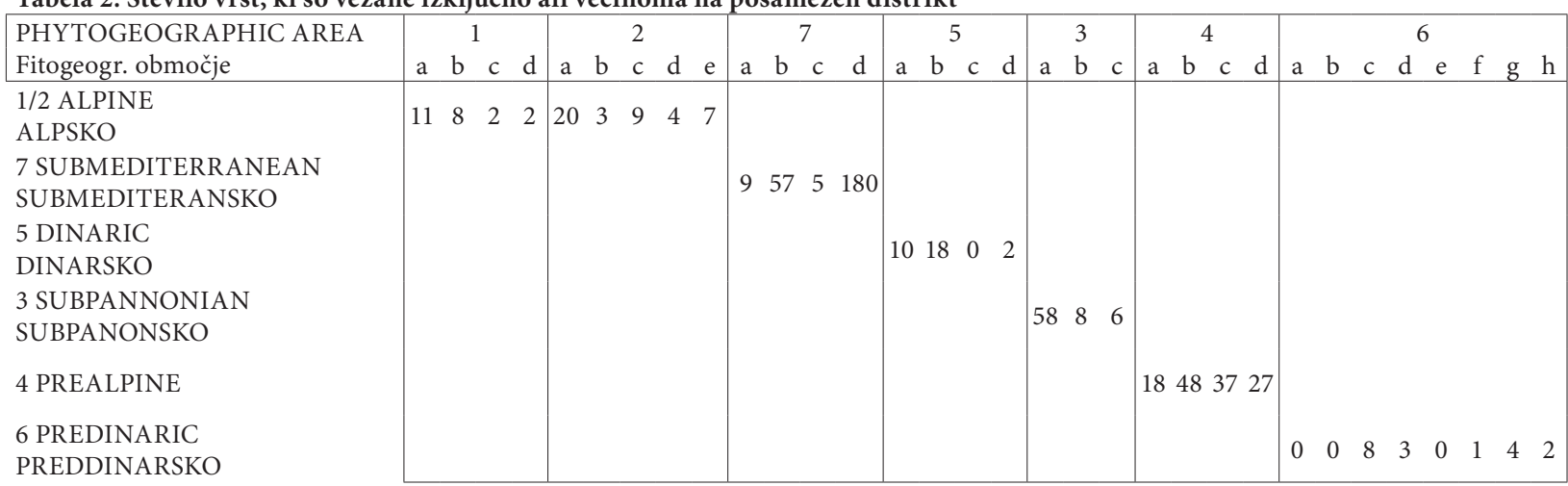




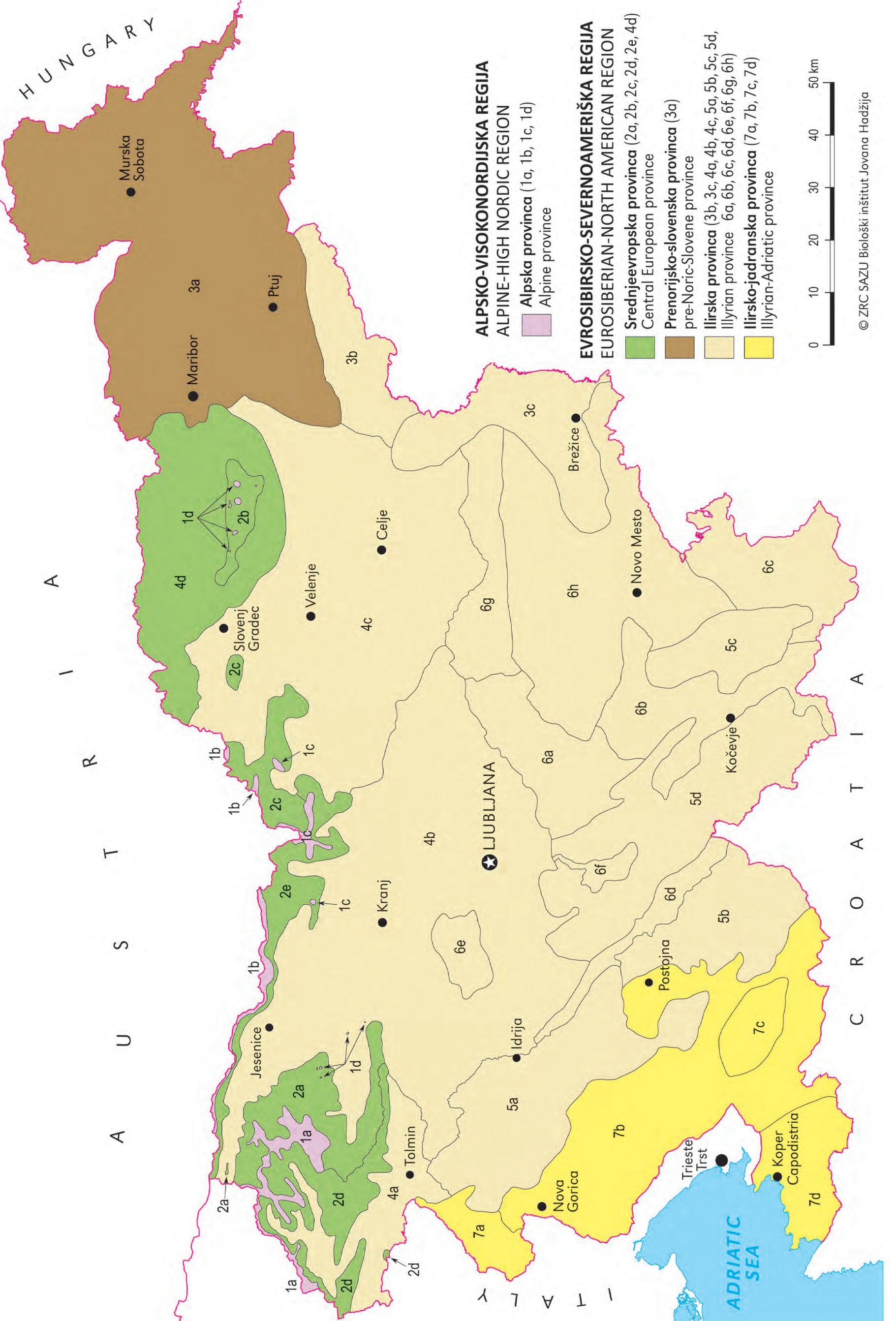


Legend of districts - Legenda distriktov:

According to Zupančič \& Vreš 2018, Map 1

(po Zupančič \& Vreš 2018, Karta 1)

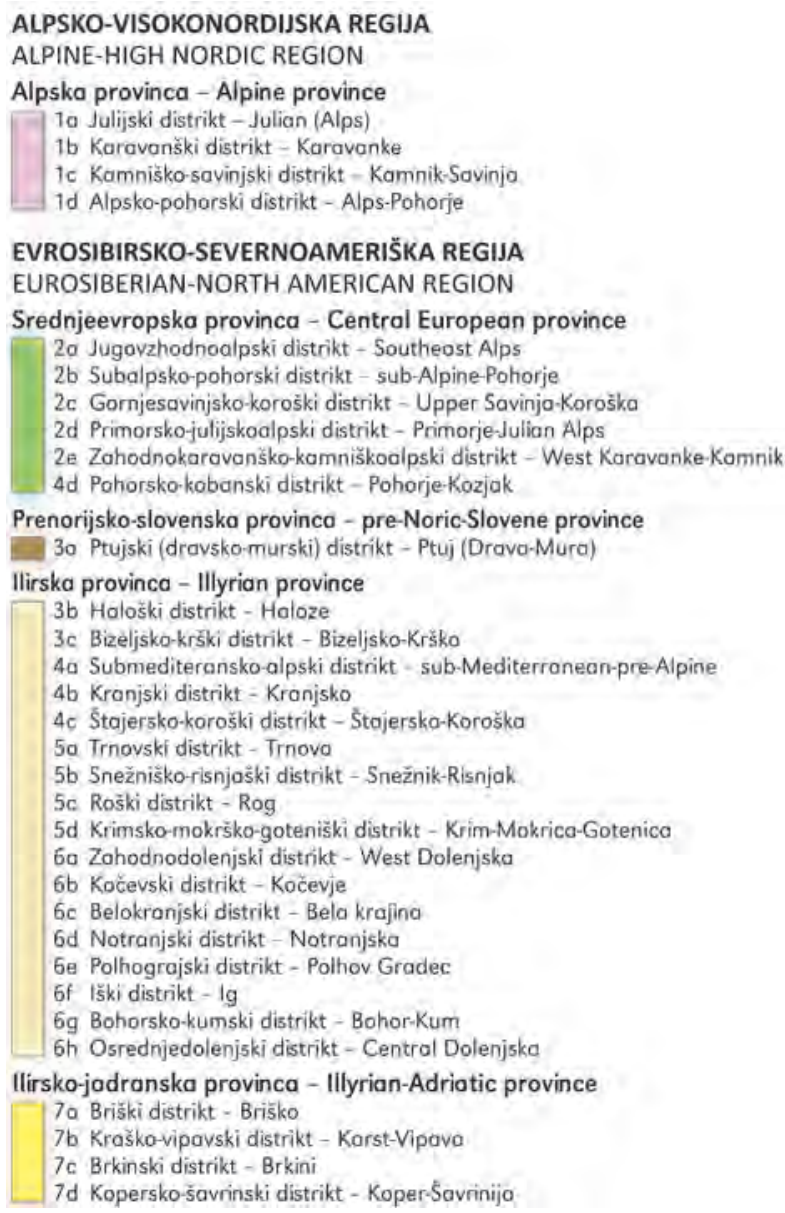

According to phytogeographic regions in M. Wraber 1969 (urejena po fitogeografskih območjih v M. Wraber 1969)

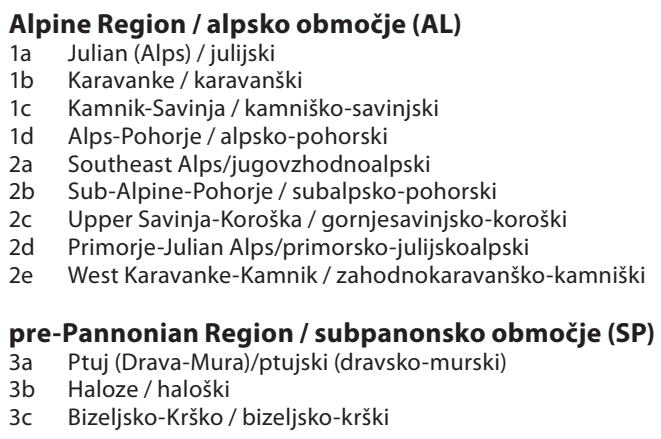

pre-Alpine Region / predalpsko območje (PA)

4a Sub-Mediterranean-pre-Alpine / submediteransko-predalpsk

4b Kranjsko/kranjski

4c Štajerska-Koroška / štajersko-koroški

4d Pohorje-Kozjak/ pohorsko-kobanski

\section{Dinaric Region / dinarsko območje (DN)}

5a Trnova / trnovski

5b Snežnik-Risnjak / snežniško-risnjaški

$5 c$ Rog/roški

5d Krim-Mokrica-Gotenica / krimsko-mokriško-goteniški

pre-Dinaric Region / preddinarsko območje (PD)

6a West Dolenjska / zahodnodolenjsk

$6 \mathrm{~b}$ Kočevje / kočevski

6c Bela krajina / belokranjski

6d Notranjska / notranjski

6e Polhov Gradec/polhograjski

$6 f \quad \mathrm{lg} /$ iški

$6 \mathrm{~g}$ Bohor-Kum / bohorsko-kumski

$6 \mathrm{~h}$ Central Dolenjska / osrednjedolenjski

sub-Mediterranean Region / submediteransko območje (SM) 7a Briško / briški

7b Karst-Vipava / kraško-vipavski

7c Brkini / brkinski

7d Koper-Šavrinija / koprsko-šavrinski

Map 1 (on the left page): Phytogeographic division of Slovenia(1:920.000).

Karta 1 (na levi strani): Fitogeografska delitev Slovenije(1:920.000). 
and 5) shows the dominance of hemicryptophytes (25 or $56 \%$ ), followed by chamaephytes (7 or $18 \%$ ), followed by geophytes (5 or 13\%), there are negligible therophytes (1 or 3\%). Phanerophytes, s lat. helophytes and hydrophites are not included among the exclusively or mostly present species (Table 22). In a comparison with other phytogeographical units, the proportion of hemicryptophytes with chamaefites is ranked third (Table 21). Table 24 shows the relationship between geoelements in the Alpine area, in which endemics (8 or $22 \%$ ) and alpine endemics (5 or 14\%) predominate. Other geoelements from the aforementioned units indicate the cold alpine conditions in the south-eastern Alps. In comparison with other phytogeographical areas of Slovenia (Table 23), alpine endemic species (5 or $62 \%)$ stand out in the Alpine area: Jovibarba arenaria, Artemisia genipi, Minuartia rupestris, Primula villosa, Taraxacum cuculatum and the Eastern AlpineIllyrian endemic Viola zoysii, as well as other endemics characteristic of the south-eastern Appenine Alps: Androsace helvetica, A. hausmanii, Papaver alpinum subsp. victoris, Festuca alpestris, Geranium argenteum, Poa cenisia etc. In addition to the pre-Alpine and subMediterranean areas, the Alpine area is rich in endemics. Table 23 shows the appearance of other geoelements, which are less numerous in comparison with other areas, in particular the pre-Alpine areas, but highlight the cold alpine conditions mentioned above.

The most floristically supported with exclusive or mainly growing species is the Southeast Alps district (2a), and with less exclusive species the Alps-Pohorje (1d) and the Primorje-Julian Alps districts (2d), but which does not mean that they do not have their own particularities in the narrower and wider circle of the phytogeographical division of Slovenia (Tables 3, 4 and 5). In particular, they differ from other districts due to the thermal influence of the Pannonian climate (AlpsPohorje district (1d) and the Mediterranean climate (Primorje-Julian Alps (2d)), which allows the occurrence of some thermophilous plant species, which are widespread in the sub-Pannonian and sub-Mediterranean area and are not present exclusively or predominantly here.

Analysis of the exclusively or mainly present species of the pre-Alpine phytogeographical area (Tables 6, 7 and 8) shows the high prevalence of hemicryptophytes (65 or $49 \%$ ). Terophytes (25 or $19 \%$ ) and geophytes (19 or 14\%) are also numerous. Unlike the Alpine area, phanerophytes ( 8 or $6 \%$ ) and nano-phanerophytes (1 or $1 \%)$ occur among exclusively or mainly present species. There are also some chamaephytes $(9$ or $6 \%$ ). There are also heliophytes and hydrophytes (each of 2 or 2-3\%) (Table 22). The distribution of spe- cies by biological form compared to other phytogeographical areas (Table 21) shows that the pre-Alpine area is rich in hemicryptophytes, similar to the subMediterranean (65 or 33\%); it also exceeds numerically in other biological forms, except in comparison with the sub-Mediteranean region, which is generally richer in the diversity of biological forms. The range of species in terms of biological form indicates more moderate living conditions, which are also reflected in the presence of terophytes and phanerophytes. Comparison of geoelements with the Alpine phytogeographical area shows a certain similarity and, at the same time, a certain diversity that is inherent due to the presence of rare individual species. Some geoelements are even represented in a minority in comparison with other areas, but they provide a specific phytogeographical character, such as Stenomediterranean and South East European geoelements. (Table 24). A particularity of the pre-Alpine area is the presence of endemics (7 or $6 \%$ ) or Alpine endemics (2 or $2 \%$ ) in valeys or in higher locations of the pre-Alpine area. These are: Euphorbia kerneri, Leontodon berinii, L. hispidus subsp. brumatii, Polygala croatica, Gentianella aspera, Thesium rostratum and Jovibarba hirta. Geoelements within the preAlpine region are shown comparatively in Table 24, whereby geoelements of the European-East European region prevail, with the insertion of Mediterranean and Eastern - (Asian) geoelements. All districts (4a to 4d) are well supported floristically.

An analysis of exclusively or mainly present species in the Dinaric phytogeographical area (Tables 9, 10 and 11) shows that it contains most hemicryptophytes (17 or $58 \%$ ). Terophytes (5 or $14 \%$ ), phanerophytes (5 or $17 \%$ ) and chamaephytes (3 or 9\%) are modestly represented (Table 22). Compared to other areas, there is modest representation of exclusive species in the Dinaric area, and so a modest representation of these species in individual categories of biological forms (Table 21) is also evident. Comparing biological forms with other areas does not provide a picture of living conditions in the Dinaric area (Diagram 1). This can only be done by comparison within an area, in which a predominance of hemicryptophytes provides an image of more difficult but not extreme site conditions.

The diversity of geoelements in the Dinaric area is modest, with only a few endemics: e.g. Hladnikia pastinacifolia in Ranunculus wraberi. Southeast European, European-Asian and Mediterranean geoelements are represented by two species each, others are represented by only one species (Table 24). In contrast with other areas, Southwest or Central European and Mediterranean-West Asian geoelements are represented here. A particularity is the presence of 16 Illyrian geoelements 
(Table 23). The distribution of geoelements shows that the Dinaric area belongs to the European-South European region.

Districts $5 \mathrm{a}, \mathrm{b}$ and $\mathrm{d}$ are supported by exclusively or mainly present species. Mokrica-Gotenica and Krim districts have very few exclusive species and are neither floristically nor vegetationally supported. It would be prudent to combine them together to the Krim-Mokrica-Gotenica district (5 d). According to DAKsкobler (2015), it is questionable to classify the Banjšice plateau into the Trnovo District (5a), since it is the transitional area between the sub-Mediterranean and the pre-Alpine phytogeographical area (KALIGARIČ \& ŠKORNIK 2002).

There are even fewer exclusively or mostly present species in the pre-Dinaric phytogeographical area than in the Dinaric area (Tables 12, 13 in 14). Both areas are floristically characterised by southeastern EuropeanIllyrian species, which in terms of number and mass are found similarly in both areas, and both exclusively or mostly present species in one or other area. As in the Dinaric area, predominantly hemicryptophytes appear in the pre-Dinaric area (4 or 44\%). Phanerophytes and terophytes (with 2 species or 22\%) are also notable. There are no exclusive species of heliophytes or hydrophytes here (Table 22). In comparison with other areas, this area is poorest in exclusive or predominant species, resulting in a modest proportion of biological forms (Table 21). It is difficult to evaluate living conditions based on biological forms. The percentage of geoelements in the pre-Dinaric area is uniform (Table 24). In comparison with other areas, only two geoelements stand out, which are not found in other areas, namely Southwest and Mediterranean-Asian geoelements. Other geoelements that are mostly present in the Dinaric area, give the warm imprint of SouthSoutheast Europe (Table 23). In view of the modesty of species in the categories of life forms and geoelements, we can infer with reservations favorable vegetation living conditions in the pre-Dinaric area.

Of the eight districts in the pre-Dinaric area, only in five districts are present some rare exclusively or predominantly present species. A division into 8 districts is justified on the basis of the floristic and vegetational analysis of ZupANČič and ŽAGAR (1995).

The sub-Mediterranean phytogeographical area is the richest in exclusively or predominantly present species (Tables 15, 16 and 17). The analysis of biological forms is more or less balanced - with the exception that there are no helophytes. Four categories are predominant: numerous terophytes (115 or $44 \%$ ), followed by hemicryptophytes (67 or $26 \%$ ), followed by geophytes $(28$ or $11 \%)$ and phanerophytes (28 or $11 \%)$.
Chamaephytes (13 or $5 \%$ ) and hydrophytes (8 or $3 \%$ ) are less represented (Table 22). The distribution or proportion of species according to biological forms compared to other areas shows the following image: terophytes are $66 \%$, phanerophytes $61 \%$, nanophanerophytes $56 \%$, geophytes $45 \%$, hydrophytes $44 \%$, chamaephytes $35 \%$ and hemicryptophytes $34 \%$. Comparison between areas shows that the sub-Mediterranean area is leading in all categories, except in the case of heliophytes. The high representation of terophytes and phanerophytes s. lat. highlights the warm dry subMediterranean conditions. Geophytes occur only in spring and survive drought with underground plant organs. The numerous hemicryptophytes indicates the unfavourable seasonal conditions. (Tables 21 and 22).

The sub-Mediterranean phytogeographical area is rich in exclusively or mainly present geoelements, highlighting the warm climatic conditions and consistent with the distribution of biological forms. The phytogeographical position of the area can be synthesized as European-Mediterranean, with influences from the Atlantic in the west and the warm part of the continent in the east (Table 24).

All districts of the sub-Mediterranean area were floristically evaluated. Karst-Vipava (7 b) and KoperŠavrinija districts (7 d) have most exclusively or mostly present species. Briška (7 a) and Brkini (7 c) districts have the least exclusively or mostly present species. Koper-Šavrinija district (7 d) is the warmest and dryest Mediterranean, which is reflected in the many species of terophytes and Stenomediterranean, Euro-Mediterranean and fewer subtropical geoelements (Table 15). On the south-eastern side, however, on the basis of the moderate representation of Euro-Mediterranean-Turanian and Southeast-South-Siberian regions we can conclude similar but numerically fewer geoelements. The endemic Moehringia tommasinii is present among exclusive species (Tables 16 and 17).

It is interesting that there are 5 endemics among exclusive species in the Karst-Vipava District (7b): $\mathrm{Hi}$ eracium dragicola, Moehringia tommasinii, Sorbus istriaca, S. mayeri and S. slavnicensis, which gives the district its own character; thus Slovenian and northernAdriatic sub-Mediterranean (Tables 15 and 17).

An analysis of exclusively or mainly present species in the sub-Panonnian phytogeographical area (Tables 18,19 and 20) shows that terophytes (26 or 41\%) are most numerous, followed by hemicryptophytes (17 or $27 \%)$. In addition to terophytes, which mark the "steppe" area, there are also hydrophytes (7 or $11 \%$ ), which inhabit wetlands, backwaters of the Mura River, or flooded abandoned gravel pits etc. (Table 22). In comparison with other areas in the sub-Panonnian area, hydro- 
phytes (7 or 39\%) stand out, similar to those in the subMediterranean area (8 or $44 \%$ ). The percentage participation of species of other biological forms is fairly similar to the pre-Alpine area; these are better represented here than in the Alpine, Dinaric or pre-Dinaric areas. (Table 21). It can be concluded on the basis of the proportion of biological forms in the sub-Panonnian phytogeographical area that growth conditions for the vegetation are relatively favorable, in view of the increased occurrence of terophytes and nanophanerophytes. They indicate a warm climate, which can be disadvantageous due to drought in excessively hot periods.

The occurrence of exclusive geoelements in the sub-Panonnian region is modest and individual (6 species, one recording or specimen each, Table 23). Other geoelements are consistent with the sub-Mediterranean region and are rarely classified as „mostly present“. Geoelements are most often represented with only one species. A protected species was recorded in the Haloze District (3b), the endemic Sempervivum juvanii (Donačka gora - quartz limestone sandstone and conglomerate). Analysis of geoelements gives a Southeast European-European-East European-CarpathianAsian character. (Table 24). This definition can be deduced from Table 23, which shows the percentage of geoelements in comparison with other phytogeographical areas.

All three districts of the sub-Pannonian phytogeographical area are floristically supported (Tables 1820), in particular the Drava-Mura district (3a), which we propose as the Ptuj Dictrict (Soó 1961), is in the pre-Noricum-Slovenian floral province (Meusel et al., 1965). In terms of number of species, this district is most Pannonian ("steppe") with numerous terophytic and eastern geoelements. The selected (exclusively or mostly present) species of this district are classified primarily as terophytes in terms of biological forms (Table 19), of which there are $24(46 \%)$ and hemicryptophytes with 10 (19\%). Six (12\%) hydrophytes occur, due to oxbowlakes, fishponds, ponds that have been created from abandoned gravel pits and occasional influxes of water, and other wetlands. There are as many geophytes $6(12 \%)$. There are 3 chamaephytes (6\%). Nanophanerophytes $2(4 \%)$ and phanerophytes $2(1 \%)$ are rare. The real image of the phytogeographical area or floristic province is given by terophytes, which are leading for the lowland, arable sub-Pannonian area or, more precisely, to the rim of the sub-Pannonian region of Slovenia. In addition to terophytes, hygrophytes that inhabit the numerous wetlands there are also typical of the area under consideration and, consequently, also for the Ptuj district of the pre-Pannonian-Slovenian floral province (Table 19).
The determination of exclusively or predominantly present species according to phytogeographical prevalence (Table 20) is the following. There are most Eurasian (8 or 15\%), Sub-cosmopolitan (6 or 11\%), Euro-Siberian (5 or 10\%), South European-South Siberian (5 or $10 \%)$, Sub-tropical (4 or 8\%) and South European (3 or $6 \%$ geoelements. This is half of all exclusively or mostly present species, which are phytogeographically well defined by the Ptuj District of the Pre-Noricum-Slovenian province of our northeastern peripheral sub-Pannonian region. Even less represented geoelements should be added to these diagnostic species of the Ptuj district, such as: East European (2 or 4\%), Pontian, Paleosubtropical, Circumboreal, Stenomediterranean, Northern Mediterranean-Montane, Euro-Mediterranean-Turanian, Southeast European, European-Caucasian, Eastern Mediterranean and Paleotemperate geoelements (each represented by 1 species or 2\%). Other geoelements in Table 20 are also found in other districts.

We also made an analysis of the appearance of Southeast European-Illyrian elements in the Ptuj district in order to assess the influence of the neighbouring Illyrian province on the southern and south-western border, that is, with the Bizeljsko-Krško (3c) and Štajerska-Koroška districts (4c). Of Southeast European-Illyrian geoelements, only the species Aposeris foetida with a narrow distribution and the widespread species Knautia drymeia subsp. drymea and Fraxinus angustifolia subsp. oxycarpa occur. The following Southeast European-Illyrian species are rarely or very rarely found in the western tip: Anemone trifolia, Cardamine trifolia, C. enneaphyllos, C. waldsteinii and Aremonia agrimonioides, and in the southern area the species: Hacquetia epipactis, Hieracium transsilvanicum and Festuca drymeia; and the species Lamium orvala, Polystichum setiferum, Erythronium dens-canis and Tamus communis are scattered throughout the area. Most of these species thrive better on basal soils and on a carbonate geological base; exceptions are Erhythronium dens-canis and Hieracium transsilvanicum, which grow on acid soils, and the species Festuca drymeia and Polystichum setiferum, which are adaptable and thrive on moderate acidic to basal soils.

Individual, rare occurrences of Southeast European-Illyrian species and the more frequent but not so diagnostically important Southeast European-Illyrian species, Aposeris foetida and Knautia drymeia subsp. drymeia, together indicate a certain differentiation of the Ptuj district within the pre-Noricum-Slovenian province. It is particularly well characterized by the species Fraxinus angustifolia subsp. oxycarpa, which is present exclusively in the Slovenian sub-Pannonian rim. 
The floristic analysis of the Ptuj area of the prePannonian-Slovenian province is followed by a vegetation analysis of forest communities that are typical of it and are mostly or only distributed here. These are: Vicio oroboidi-Fagetum (Ht. 1938), Pocs \& Borhidi in Borhidi 1960, Polysticho setiferi-Fagetum Zupančič et al. 2001 (non Ubaldi 1988 nom. inv.), Festuco drymeiae-Abietetum Vukelić \& Baričević 2007, Pruno padiCarpinetum betuli (Marinček \& Zupančič 1982) Marinček 1994, Hieracio rotundati-Fagetum Ž. Košir 1994, Galio rotundifolii-Pinetum Zupančič \& Čarni ex Čarni et al. 1992, Pruno padi-Fraxinetum angustifoliae Čarni et al. 2008 nom. nud., Fraxino-Ulmetum effusae Slavnić 1952 var. Prunus padus Vukelić et Baričević 2004, Salicetum albae-fragilis Soó (1930) 1940, Querco roboris-Carpinetum M. Wraber 1969, Stellario nemorum-Alnetum glutinosae Lohmayer (1953) 1957, Lonice- ro caprifolii-Quercetum roboris (Rauš 1971) Marinček 1994 and Querco roboris-Ulmetum minoris Issler 1924. Of grassland communities, characteristic species (described for the first time here) for the area would be Dactylis glomerata-Festuca pratensis comm. (A. Seliškar 1998) and later discovered dry or semidry grasslands Hypochoerido-Festucetum rupicolae Steinbuch 1995 and Onobrychido viciifoliae-Brometum Kaligarič et Škornik 2002 of Slovenian sub-Pannonean region (KALIGARIČ \& ŠKORNIK 2002, ŠKORNIK 2003). As has already been noted, there are a number of wetlands in the area under consideration, which are covered by a number (nine) of wetland associations of the classes Lemnetea, Isoeto-Nanojuncetea, Galio-Urticetea and Phragmiti-Magnocaricetea, which give their own character to the province, and thus also the Ptuj district, and the pre-Noricum-Slovenian province.

\section{COMPARISON BETWEEN ANALYSES OF SELECTED AND ALL TAXONS IN THE PHYTOGEOGRAPHIC AREAS OF SLOVENIA}

For comparison, we analyzed the biological forms of taxons among the exclusively or mostly present (selected species) and all the growing species of Slovenia in individual phytogeographical areas according to $\mathrm{M}$. WRABER (1969), in order to determine the coherence or diversity of the results of the relationships among biological forms. We used 3240 taxons for processing by FloVegSi (T. SelišKar et al. 2003) (Diagrams 1 and 2).

In the Alpine phytogeographical area, the ratios of biological forms are for the most part more or less consistent. (Table 22, Diagram 1). There is a difference with phanerophytes, which are missing in the analysis of exclusive or mostly present species (Table 22). This is explained by the fact that tree species present here (e.g., larch, spruce, fir, beech, white maple etc.) also occur in other phytogeographical areas. We were surprised by the number of terophytes in the Alpine area (Diagram 1), in which we did not expect such a high proportion. This is attributed to the excessively wide Alpine area of M. Wraber (1969) towards the lower pre-Alpine area.

In the pre-Alpine phytogeographical area, the two analyses of biological forms are consistent, with negligible deviations.

Comparison of biological species in the Dinaric phytogeographical area is consistent. The difference is only in the occurence of the number of phanerophytes, which is in a ratio of as much as 15: 6 (Table 22, Diagrams 1 and 2). The Dinaric area is known for its diversity of tree (phanerophyte) and shrub (nanophan- erophyte) species. The difference is interpreted as being due to imprecise methods, which in these cases are based on approximations and are therefore relative, although they give a satisfactory result.

In the pre-Dinaric phytogeographical area, the percentage of phanerophytes differs between the analyses of selected and that of all species in Slovenia, by almost double, the least deviation being found with chamaephytes (Table 22, Diagrams 1 and 2). With other biological forms relations are consistent. In the relation between phanerophytes and chamaephytes, of the two analyses the analysis covering all plants of Slovenia is to be believed. It should be noted that for selected species, an error may have arisen due to the small number of species. It is uncertain why chamaephytes drop out in the analysis of selected species.

In the sub-Mediterranean phytogeographical area, there are percentage differences in hemicryptophytes and terophytes. There are twice as many hemicryptophytes in the analysis of all species in Slovenia, and twice as many terophytes in the analysis of selected species. Other percentages of biological species are consistent. The cause is probably in the relativity of the two analyses, whereby we cannot precisely define the boundaries of the areas with either analysis. (Table 22, Diagram 1).

There are most differences in the sub-Pannonian phytogeographical area. In the analysis of all species in Slovenia, phanerophytes and hemicryptophytes predominate; and geophytes and terophytes in the analy- 
sis of selected species (Table 22, Diagram 1). Because of completeness, the analysis of all species is more reliable and is also computer supported. Despite the differences between analyses, we believe that the relations between biological forms are very similar. In both analyses, hemicryptophytes and terophytes predominate, which is characteristic of the sub-Pannonian area. In comparison with other phytogeographical areas, hydrophytes have the highest percentages in the sub-Pannonian area in both analyses (Table 22, Diagram 1). In a similar comparison for phanerophytes, the percentages in all areas are balanced (Diagram 1).
The analysis of selected species by regions shows a below average percentage of phanerophytes in the subPannonian area, which is not realistic. The reason is similar to other phytogeographical areas, since almost all phanerophytes are predominantly present in all phytogeographical areas.

We conclude that the analysis of biological forms of all species for the most part confirms the analysis of the selected (exclusively and mostly present) species, which faithfully reflects their living conditions, both for individual taxons and for mutual growth in different vegetational forms.

\section{THE DIVISION OF SLOVENIA INTO FLORAL PROVINCES}

Slovenia is divided into two phytogeographic regions: the superficially most widespread Eurosiberian-North American region and the superficially modestly represented Alpine-Nordic region in the northwest Alps. In the context of these two regions, there are five phytogeographic provinces. In the Eurosiberian-North American region there are four: Central European on a smaller area of northern Slovenia, the Illyrian in central Slovenia has a larger area and the Illyrian-Adriatic province on the smallest area of southwest Slovenia and in the northeast a newly distinguished pre-NoricSlovene province with a minor extent. The Illyrian and Illyrian-Adriatic provinces are phytogeographically particular, distinguished from the Central European and pre-Noric-Slovene provinces by southeast European-Illyrian (Illyrian, Illyroidian) geoelements for the most part coming from the Balkan Peninsular, which are excluded here towards the east. In the Alpine-High Nordic region we have the Alpine province, which is settled by southeast-Alpine geoelements from the west and here they achieve their most easterly settlement.

In the description of new districts of Slovenia (ZuPANČIČ \& ŽAGAR 1995) we also considered the problem of the extent of the Illyrian floral province. The basic considerations derived from the research of earlier authors at the start of the twentieth century (ZuPANČIČ \& ŽAGAR 1995: 21). We relied on AdAMović's (1906) cartographic presentation of the Illyrian floral province and above all on the basic studies of Beck $(1907,1908,1913)$ and HayeK $(1907,1923)$. BECK (1907-1913) distinguished in his studies Mediterranean, Illyrian and Central European flora, which is a solid basis for delineating today's Illyrian-Adriatic, Illyrian and Central European provinces. HAYEK (1907) focused above all on the Alpine area - Kamnik Alps, which he divided into six zones: mountain (mon- tane) zone, 340-700 m (900 m), lower pre-Alpine, ((700 m) 900-1200 m), upper pre-Alpine area (1300-1628 $\mathrm{m})$, area of dwarf pine (1631-1802 m), Alpine (2020$2250 \mathrm{~m})$ and sub-nival area $(2250-2569 \mathrm{~m})$, which is a solid basis for delineating between the EurosiberianNorth American and Alpine-Nordic regions and the Alpine province. In the area under discussion, HAYEK (ibid.) additionally notes the presence of Pannonian flora but which today would not be placed there, perhaps only some species more widely understood as Pannonian species, Dianthus barbatus, Helleborus odorus, Silene viridifolia, Galium aristatum, Centaurea variegata, C. fritschii, Ophrys holosericea, Tunica saxifraga, Linum tenuifolium, L. flavum.

In his study for Štajerska, HaYeK (1923) restricts the Slovene part of Štajerska to the area from Šentilj in the north to Brežica (Obrežja) in the south and from the northern slopes of the western Kamnik Alps (Ojstrica) and the southwestern Karavanke (Olševa) to Haloze in the east. He divides this area into two phytogeographic areas: European-Siberian forest and Alpine areas. He divides the first area into districts, namely, south German, sub-Alpine and Austrian districts, and this last into four sub-districts. Of interest to us are the northeast-Alpine and Illyrian sub-districts of the subAlpine district and the Pannonian sub-district of the Austrian district. He divides the second, alpine area into the districts North Calcareous and Central Alps and South Calcareous Alps with six sub-districts. Of these six sub-districts, of interest are the Julian Alps sub-district of the Southern Calcareous Alps district and partially the Noric Alps sub-district of the Northern Calcareous and Central Alps district. For defining phytogeographic areas, districts and sub-districts, especially Illyrian ones, the distribution of some thermophilous, though generally widespread, south- 
east European-Illyrian species served him: Ostrya carpinifolia and Fraxinus ornus (its northern boundary is Dravograd-Velenje-Slov. Bistrica-Macelj-Ptuj) and Castanea sativa (northern boundary: to Graz), as well as the distribution of grapevine (northern boundary: Radlje, border with Austria-Ruše-Hoče-Slov. Bistrica and then along the boundary of distribution of the species Ostrya carpinifolia and Fraxinus ornus - Dravograd). His delineation between Illyrian and Central European phytogeographic provinces as we understand it today is surprisingly precise if we take into account the then less researched territories of Carniola and Carinthia and the modest literature. He mainly relied on Веск (1907-13).

ВесK (1907-13) investigated the Slovene ethnic territory botanically and above all phytogeographically at the end of the 19th and beginning of the 20th century. He delineated Mediterranean, Illyrian and Central European flora and showed all this on maps. He classified today's western Slovenia into the Mediterranean region all the way to Kanal, Volče and Breginj (Breginjski kot). His delineation provided a solid basis for later phytogeographers. He was precise, sometimes even very precise: an example is the described habitat of Illyrian (southeast European-Illyrian) flora in the Završnica valley below the Karavanke, namely: Aremonia agriminioides, Cardamine ennephyllos, C. trifolia, C. waldsteinii, Hacquetia epipactis, Lamium orvala, Omphalodes verna, Vicia oroboides etc.

Since the Second World war, a number of botanists and phytocenologists have followed, who have researched the phytogeographic division of Slovenia and resolved this kind of problem in various ways. Among the first phytogeographers was the botanist MAYER (1946). In his dissertation he floristically analysed the Southeast Calcareous Alps and came to the conclusion that the Eastern Calcareous Alps should be classified in the Alpine Province. He confirms this classification by the appearance of Alpine-Northern European (e.g., Nigritella nigra, Campanula barbata, Euphrasia minima), Alpine-Central European (e.g., Saxifraga caesia, Primula auricula, Soldanella alpina, Homogyne alpina), Alpine (e.g., Rumex nivalis, Androsace helvetica, Valeriana supina), Alpine-Arctic-Altai (e.g., Salix herbacea, S. reticulata, Polygonum viviparum, Androsace chamaejasme), Alpine-Arctic (e.g., Silene acaulis, Bartsia alpina, Gentiana nivalis), Alpine-Altai (e.g., Coeloglossum virde, Salix retusa, Veronica aphylla, Leontopodim alpinum) flora and endemics (e.g., Cerastium julicum, Campanula zoysii, Gentiana froelichii, Saxifraga hohenwartii, Leucanthemun lithopolitanicum, Nigritella lithopolitanica). MAYER (1950, 1951, 1952, 1953, 1960), in papers on flora later further reinforced the classifi- cation of the Slovene Eastern Calcareous Alps in the Alpine province, or showed the extent of the Illyrian Province.

The botanist Nada Praprotnik (1987), in her dissertation on Illyrian floral elements, disarticulated in detail the phytogeographic allegiance of more or less Illyrian species in Slovenia. She classified them into 13 phytogeographic units (categories) and showed their area of distribution in Slovenia. Her study well assisted recognition of the distribution of Illyrian and IllyrianAdriatic floral provinces in Slovenia. For illustration, we state some species that are mostly referred to as Illyrian species:

Illyrian floral elements: Helleborus atrorubens, Scabiosa hladnikiana, Scilla litardieri etc.

Sub-Mediterranean-Illyrian elements: Anthriscus fumaroides, Satureja subsipcata, Sesleria autumnalis etc.

Northwest Illyrian elements: Arabis scopoliana, Hladnikia pastinacifolia, Potentilla carniolica etc.

Sub-Illyrian elements: Frangula rupestris, Gentiana tergestina, Potetilla tomasiniana etc.

Alpine-Illyrian elements: Homogyne sylvestris, Lamium orvala, Vicia oroboides etc.

Apennine-Illyrian elements: Corydalis ochroleuca (Pseudofumaria alba), Genista sylvestris, Sesleria juncefolia etc.

Carpathian-Illyrian elements: Daphne blagayana, Euphrasia liburnica.

Taxons with wider areas of distribution: Cardamine kitaibelli, Epimedium alpinum, Grafia golaka etc.

Taxons with Alpine-Carpathian-Illyrian distribution: Euphorbia carniolica, Hacquetia epipectis, Hypericum alpinum etc.

Taxons with southern European, southeastern European and wider distribution: Anemone trifolia, Aremonia agriminioides, Cardamine trifolia, Geranium nodosum, Omphalodes verna etc.

Taxons that are most frequent in sub-Mediterranean associations: Fraxinus ornus, Ostrya carpinifolia, Pinus nigra etc.

Taxons that are most frequent in associations of the sub-Alpine and Alpine zones: Centaurea triumfettii, Scorzonera rosea, Thymus balcanus etc.

Taxons with unclear taxonomic position are today for the most part classified, e.g., the species Arabis alpina subsp. alpina, Asperula aristata etc. It has also been shown that the subspecies Helleborus niger subsp. macranthus does not thrive here. Helleborus niger subsp. niger grows on dolomite or a dolomitised geological base in the mountain (montane) zone.

BoRHIDI (1963) made a similar analysis of Illyrian and related species, such as Alpine-Illyrian, Carpathi- 
an-Illyrian, Pannonian-Illyrian. Italian-Illyrian, Dacian-Illyrian, sub-Mediterranean-Illyrian, Balkan etc. species, when he reasoned the Illyrian alliance of beech forests Aremonio-Fagion (=Fagion illyricum). On this floristic basis, he showed the distribution of the Illyrian alliance of beech forests (BoRHIDI 1963: 260, 266), which would correspond to the area of distribution of the Illyrian floral province. As can inferred from the picture, which is to a very small scale, the majority of Slovenia is covered by the alliance of Illyrian beech forests, which could be considered as the Illyrian floral province. Excluded are Primorje and pre-Pannonian zones of Slovenia. At this scale it is not possible to exclude the Alpine belt of Slovenia.

Horvat (1954, 1962 a) provided a phytogeographic division of Southeast Europe in which he also included Slovenia. Phytogeographic analysis, with the presentation of a map of climatogenic vegetation of Southeast Europe disarticulates climatogenic vegetation according to horizontal distribution and vertical belts. On the basis of this division, he found that according to Braun-Blanquet, there are three vegetation regions in Southeast Europe: Mediterranean, Eurosiberian-North American and Irano-Turanian. The Mediterranean-sub-Mediterranean floral region he classifies into the Mediterranean and the Central European floral region into the Eurosiberian-North American region. In a paper (HoRvat 1962 b) confirms his decision from the previously mentioned publications and outlines on a map of potential vegetation the boundary between Mediterranean and Central European regions of the four phytogeographers, Adamović, Markgraf, Oberdorfer and Rikli, which are very varied. He himself sticks with the division on the basis of potential vegetation that he presented in his works (Horvat 1954, $1962 \mathrm{a}, \mathrm{b}$ ). His map of climatogenic vegetation only embraces a minor, south-eastern part of Slovenia, which he places in the sub-Mediterranean region of (climatogenic) vegetation Carpinetum orientalis croaticum and SeslerioOstryetum.

Horvatić $(1957,1963)$ found that Mediterranean and sub-Mediterranean zones in the area of the Central Balkan peninsular (former Yugoslavia) are more mutually interconnected than the sub-Mediterranean zone with the continental area of the EurosiberianNorth American region. He classifies Mediterranean and sub-Mediterranean areas into the Mediterranean region. He divides Primorje into three zones:

1. East Adriatic eumediterranean zone (Quercion ilicis),

2. East Adriatic submediterranean zone (Carpinetum orientalis croaticum),
3. East Adriatic Mediterranean-montane zone (Seslerio autumnalis-Ostryetum).

Horvatić (1967) later divided Yugoslavian Primorje into two provinces: Adriatic and Aegean, both later in the framework of the Mediterranean region. He divided the Eurosiberian-North American region into three or four provinces: Illyrian, Mezzian, Illyrian and the Mezzian into the zone of dwarf pine and the Central European province - Pannonian sector with lowland and montane zones. He classifies Slovenia into two provinces, namely Adriatic-sub-Mediterranean (Mediterranean region) and Illyrian province (Eurosiberian-North American region). He classifies the zone of mountain vegetation into the Alpine-High Nordic region. He classifies the belt of dwarf pine into the Illyrian province.

Trinajstić $(1976,1986,1995)$, after the period of earlier Croatian phytogeographic research, dealt most and most intensively with phytogeographic questions of Croatia, especially its Primorje. If we simplify his phytogeographic division of the Kvarner Bay, which is linked towards the west to Slovene Primorje, TRINAJSTIĆ (1976) classifies the narrower sub-Mediterranean area into the Mediterranean region. He classifies the para-Mediterranean zone, i.e., the littoral belt with thermophilous beech forests, into the Eurosiberian-North American region, together with Illyrian, Dinaric, sub-Illyrian-sub-Alpine (interesting!), borealsubalpine, Illyrian-Balkan, subalpine-Illyrian-Balkan vegetation zones. We can in principle agree with his phytogeographic division for Slovene Istria. TRINAJSTIĆ (1995) later phytogeographically disarticulated forest vegetation of Croatia in more detail. He dealt in particular with the phytogeographic division of the Eurosiberian-North American region. His division of this region is interesting and acceptable (TrinajsTIĆ 1995: $40-42$ ). He does not change the Mediterranean region as shown in 1986 (Trinajstić 1986) and it is phytogeographically suitably arranged into Mediterranean-littoral and Mediterranean-montane zones. The question is raised of whether it is correct that he ranks the subMediterranean vegetation zone of the Mediterraneanlittoral zone into the Mediterranean region.

Sugar thoroughly researched the area of Croatian Istria, which is the direct neighbour of Slovene Istria. His thesis is that the sub-Mediterranean area (in the wider sense) of Istria classifies into the Central European-North American and not into the Mediterranean region. The question is where to classify the zone in which is retained the occurrence of holm oak - Quercus ilex (ŠUGAR, 1984). ŠUgAR et al. (1995) divide the Istrian sub-Mediterranean into submediterranean (QuercoCarpinetum orientalis), epimediterranean (Ostryo- 
Quercetum pubescentis), histrian (Molinio-Quercetum pubesce-ntis, Potentillo albae-Querceetum pubescentis) and paramediterranean zones (Seslerio-Fagetum), of the Eurosiberian-North American region, in which he classifies the Illyrian zone (Fagetum s. lat.), and he places the precoastal, eumediterranean zone (OrnoQuerectum ilicis) in the Mediterranean region. The zone of evergreen vegetation (Quercetum ilicis) is only on the Brioni islands. The mountainous part of Istria embraces the Illyrian zone (Seslerion tenuifoliae) of the oromediterranean (Mediterranean-montane) region.

The phytogeographic division of Slovenia of $\mathrm{M}$. Wraber (1969) is important for determining the Illyrian floral province in Slovenia. This is the first cartographic presentation of the phytogeographic division of Slovenia on a floristic and vegetational basis. On the basis of his division, we can conclude the existence of various floristic provinces in Slovenia. M. Wraber (ibid.) finds that the Central European province extends into the north and west of Slovenia and the Illyrian province with Illyrian-Balkan plants into the southeast. The southern part of Slovenia is Mediterranean, Mediterranean-montane and sub-Mediterranean. According to his phytogeographic map and judging by his thinking, the Alpine area belongs in the Central European province but in the lowlands with Illyrian-Balkan and Illyrian-southern European elements. He defines the pre-Alpine and pre-Dinaric area as a mixture of Alpine-Central European and IllyrianDinaric geoelements. Illyrian-Balkan flora characterises the Dinaric area. The sub-Pannonian area has a Pannonian vegetational character (without explicit Pannonian species, author's note) where here and there Illyrian flora appears. In the neighbouring Hungarian Pannonian area, they are classified into the pre-Noric province with the districts Castriferricum and Poetovicum, in which our sub-Pannonian area would be included. He classifies the sub-Mediterranean area into the Adriatic province, which here is concluded or, as he says, »disappears«. (ibid.)

Ž. KošıR (1975) divided Slovenia into five phytoclimatic territories: sub-Mediterranean, Dinaric, Alpine and pre-Alpine, pre-Dinaric and sub-Pannonian territories. It is not possible to infer the boundary between floristic provinces from the phytoclimatic territories. We find, however, that except for the pre-Dinaric phytoclimate, all other phytoclimates are identical to the phytogeographic areas of M. Wraber. From the distributional area of Koširss pre-Dinaric phytoclimate, we can conclude that, according to his Illyrian floral province, it reaches deeply into the north-eastern and partially eastern part of Slovenia, extending into neighbouring southern Austria, which already belongs in the Noric floral province. Koširss decision for such an extensive Illyrian floral province derives from the Potential Phytocoenological Map of the Bureau of Forestry Planning to a scale of $1: 100.000$, which shows a considerable share of basal to moderately acidic beech forest Hedero-Fagetum (Querco-Fagetum) and sub-Pannonian moderately basal to neutral (poorly acidic) beech forest (Festuco drymeiae-Fagetum). More recent research has established different thinking in terms of the share of area of one and the other. More recent research shows a different image of the forest vegetation, supplemented with non-forest associations and floristic studies.

MARINČEK (1994), on the basis of the vegetation and some Illyrian species, proposes a boundary of the Illyrian floral province in the central Balkan Peninsula or on the territory of former Yugoslavia. In view of the loose definition and on the basis of general phytogeographic maps of unknown scale, we can conclude that the Illyrian floral province extends from Slovenia to Macedonia, without a coastal belt, and in the northeast cuts into the Mezian floral province. Individual islands of the Illyrian floral province also extend into the Pannonian-Mezian area. The Illyrian floral province divides into four areas: a pre-Alpine area in the west, sub-Pannonian area from the northwest to northeast, Dinaric area from the southeast to southwest and pre-Dinaric area in an intermediate ragged zone between the sub-Pannonian and Dinaric areas. Marinček considerably generalised the mentioned phytogeographic areas and to a large extent copied Meusel et al. (1965). According to Marinček, all four areas are present in Slovenia.

Meusel et al. (1965) showed in a comparative horology for Central European flora that Slovenia lies in the area of the western Illyrian and pre-Noric-Slovene floristic provinces. The map is very generalised. The definition of the pre-Noric-Slovene floristic province is interesting, which more or less corresponds to Hungarian botany or phytocenology (Soó 1961, Pocs 1960, KARPATI 1966).

Zupančič et al. (1987) (ZupanČIČ \& ŽAGAR 1995) supplemented the basic phytogeographic division of Slovenia of M. Wraber (1969). In both cases it was a supplement on the level of districts. Today we recognise 32 districts that are based on the particularities of the flora and vegetation. We classify the districts into four provinces (or five provinces) and two regions:

Alpine-High Nordic region:

Alpine province with four districts;

Eurosiberian-North American region:

Central European province with five districts, Illyrian province with eighteen districts and 
Illyrian-Adriatic province with four districts and pre-Noric-Slovene province with one district. M. Wraber (1969), Horvat (1954, 1962 a, b), Horvatić $(1957,1963,1967)$, Trinajstić $(1976,1986$, 1995), Zupančič et al. (1982), ZupanČIČ \& ŽAGAR (1995) classified the Slovene sub-Mediterranean area into the Mediterranean region. ŠUGAR (1984), in view of the mixed deciduous and evergreen forests and scrub, classified the Croatian and Slovene sub-Mediterranean area into the Eurosiberian-North American region. With certain doubts and reservations, the coauthors of a paper on forests of downy oak and moorgrass growing in the area of Croatian and Slovene Is- tria (ŠUgAR et al. 1995) accepted these ideas. Further research of vegetation showed that the Slovene subMediterranean area, which extends highest towards the northwest of Slovenia, towards the west Julian Alps, is classified in the Eurosiberian-North American region (Zupančič 1997). In the Slovene sub-Mediterranean area, there are for the most part deciduous and a small share of evergreen trees or shrubs in forestshrub associations. Our sub-Mediterranean has a colder climate and is damper than in the southeast area of the Balkan peninsular. OGRIN (1995) says that the Slovene sub-Mediterranean area is moderately warm with a damp climate, where only summers are warm.

\section{CONCLUSION}

We wish to define and delineate the area of the Illyrian floral province in Slovenia on the basis of the occurrence of southeast European-Illyrian (Illyrian, Illyricoid, sub-Illyrian) species in individual phytogeographic units - districts, in entirety or their parts, and on the basis of the results of phytogeographic research of the scientists mentioned in the chapter that discusses the problems of division into floral provinces. We have taken into account more or less all the stated researchers but we have relied most on BECK $(1907,1908$, 1913), Наyek (1907, 1923), Horvat (1954, 1962 A, B), Horvatić $(1957,1963,1967)$, Košir (1975), MaYer (1946, 1950,1951，1952，1953，1960), ŠUGAR (1984), ŠUgar et al. (1995), TrinajStić (1976, 1986, 1995), Wraber (1969), ZUPANČIČ et al. (1987) and ZUPANČIČ \& ŽAGAR (1995).

As a basis for a graphic depiction of the Illyrian floral province we have taken the phytogeographic maps of Wraber (1969) and Zupančič et al. (1987, ZUPANČIČ \& ŽAGAR 1995).

In relation to WrabeR's (1969) phytogeographic map, the Illyrian province is limited to the northeast with the Central European floral province in the extreme area of the sub-Pannonian phytogeographic area and to the narrow northern edge of the Alpine phytogeographic area. From the Illyrian floral province is extracted the sub-Mediterranean phytogeographic area, which we classify into the related Illyrian-Adriatic province, with many thermophilous geoelements.

The more detailed phytogeographic map of ZuPANČIČ et al. (1987) (ZuPANČIČ \& ŽAGAR 1995) is divided into districts. On the basis of districts, we find that the Illyrian floral province extends into the majority of districts, except into districts 1a-1d, which belong to the Alpine floral province, $2 \mathrm{a}-2 \mathrm{c}, 3 \mathrm{a}$ and the northern part of district $4 \mathrm{c}$, which we classify into the Central European floral province, and districts $7 \mathrm{a}-7 \mathrm{~d}$, which belong to the Illyrian-Adriatic floral province.

In forming the Illyrian floral province, we have some hesitations. First, the division of district $4 \mathrm{c}$. The northern part of the district embraces the silicate area of Pohorje, Strojna and Kozjak (Kobansko), which we classify into the Central European floral province. We should probably exclude this area from district $4 \mathrm{c}$ and create a special new district (4d). Second, perhaps district 3a should be classified into the pre-Noric province in the district Poetovicum (Karpati 1966, Pocs 1960, Soó 1961) or the pre-Noric-Slovene (Meusel et al. 1965) province. Third, is an independent IllyrianAdriatic floristic province justified or should it be included in the Illyrian province, which extends into the continental area of Slovenia?

It is easiest to answer the third question. The Illyrian-Adriatic floristic province is determined by Illyrian-Mediterranean species (e.g. Carpinus orientalis, Eryngium amethystinum, Paliurus spina-christi, Sesleria autumnalis, Scorzonera villosa etc.), Illyrian-Adriatic species (e.g. Dianthus tergestinus, Drypis spinosa, Genista sylvestris etc.) and Illyrian-Apennine species (e.g. Ruta graveolens etc.), among which are endemic species and many sub-Mediterranean and Mediterranean species, such as Mediterranean-Pontic (e.g. Ruscus aculeatus, Chrysopogon gryllus idr.) or Mediterranean-Atlantic (e.g. Euphorbia peplis, Oenanthe pimpinelloides, Avena barbarta etc.) and many other species.

District $4 \mathrm{c}$ would indicate division into two parts: the current Štajerska-Koroška $4 \mathrm{c}$ and a new PohorjeKozjak district $4 \mathrm{~d}$. It is necessary to study in what the districts differ, what is the floristic and vegetational, 
climatological and pedological difference between them. They certainly differ in geological base and also more or less in terms of soil. A brief review of plant species shows that 16 species thrive exclusively only in the Pohorje-Kozjak district ( $4 \mathrm{~d})$. Of these we mention only the rarest or most interesting, namely: Asplenium adulterinum, A. cuneifolium, Botrychium multifidum, Saxifraga paradoxa and Heliosperma veselskyi subsp. widderi.

In the phytogeographic division of Zupančič et al. (1982) (ZupančIČ \& ŽAGAR 1995), the Ptuj (Drava-Mura) district (3a) is classified as an exception in the transalpine sector and a special pre-Pannonian subsector, whereby both belong to the Central European province. The name of the sector indicates that the area is transalpine or on the other side of the Alps (Leksikon CZ 1988). The eastern edge of the Central Alps (Krka Alps, Svinška planina, Golica, Pohorje) climatically influences the lowland-hilly world of Slovenske gorice, which have the most expressed continental climate on the territory of Slovenia. It would probably be a better systemic solution to classify the Ptuj (Drava-Mura) district (3a) into the pre-Noric-Slovene province according to Meusel et al. (1965) with transalpine sector and pre-Pannonian subsector. There would thus be five provinces in Slovenia, so four provinces in the Eurosiberian-North American region.

The area of the floristic provinces is evident from the phytogeographic map of Slovenia to a scale of 1:920.000 (Map 1). 


\section{UVOD}

Leta 1969 je M. Wraber (1969) na podlagi tedanjega poznavanja gozdne vegetacije zasnoval fitogeografsko delitev Slovenije na šest območij: alpsko, predalpsko, dinarsko, preddinarsko, submediteransko in subpanonsko fitogeografsko območje. Ob novih vedenjih o vegetaciji Slovenije in upoštevanju flore so bila fitogeografska območja razdeljena na nižje enote distrikte, dopolnjene ali popravljene pa so bile meje oz. razmejitve med območji, zlasti med alpskim in predalpskim območjem. Hkrati je bila želja avtorjev, da te fitogeografske enote uvrstimo $v$ ustrezne standardno veljavne rastlinske province, kar je bilo tudi narejeno (Zupančič et al. 1987).

$\mathrm{V}$ povezavi s pojavljanjem flore oz. posameznih vrst, ki so izključno ali večinoma prisotne $\mathrm{v}$ določenem fitogeografskem območju in v posameznem distriktu, smo želeli potrditi pravilnost omejitve ali zamejitve posameznega območja oziroma distrikta. Na podlagi kart razširjenosti vrst v Gradivu za Atlas flore Slovenije (Jogan et. al. 2001) ter horoloških podatkov iz podatkovne zbirke FloVegSi (T. SelišKa et al. 2003) smo na poenostavljen način $z$ rastrom fitogeografskih območij in distriktov s pomočjo izbranih/opredeljenih diagnostičnih vrst ugotavljali izključno ali večinoma prisotno floro za posamezno fitogeografsko območje oz. podrejeno fitogeografsko enoto (distrikt). Diagnostične vrste smo opredelili kot: (i) izključno prisotne vrste (take, ki se pojavljajo izključno samo v enem območju) in (ii) večinoma prisotne vrste (take, ki so večinoma razširjene le v enem območju in imajo $\mathrm{v}$ redkih drugih območjih le še nekaj posameznih nahajališč). Preprost način za ugotavljanje prisotnosti flore je relativen, $\mathrm{z}$ določenim odstopanjem, kot je glede na pogostnost taksona $\mathrm{v}$ karti razširjenosti vrste, podvrste, varietete, količinsko nedoločena: oznaka za prisotnost vrste $\mathrm{v}$ kvadrantu lahko pomeni obstoj/prisotnost enega ali več nahajališč vrste oz. pojavljanje več primerkov rastline ali pa le enega samega. Kljub temu je informacija dovolj povedna in uporabna. Poleg upoštevanja zdaj znane slovenske razširjenosti taksona smo pri analizi uporabili še njegovo širšo (zemeljsko) horološko pripadnost (geoelement, florni element) in biološko obliko. Ta elementa nam kažeta biološke in ekološke razmere glede življenjskih razmer, v katerih rastlina uspeva.

Razprava je razdeljena na dve poglavji. V prvem poglavju ugotavljamo pogostnost rastlinskih vrst $\mathrm{v}$ fitogeografskih območjih oziroma distriktih, kar je osnova za drugo poglavje o razdelitvi Slovenije na florne province. Poleg flore, vegetacije in obstoječe fitogeografske razdelitve Slovenije smo upoštevali še objave najbolj relevantnih botanikov - fitogeografov iz starejšega obdobja, katerih dela so posredno ali neposredno vezana na Slovenijo, kot so: AdAmović (1906), Веск (1907, 1908, 1913), НАYек (1907, 1923); Horvat $(1954,1962)$, Horvatić $(1957,1963)$, Mayer (1946, 1950, 1951, 1952, 1953, 1960), Meusel et al. (1965), M. Wraber (1969), Soó (1961), Pocs (1960), Karpati (1966). Upoštevali smo tudi dela botanikov in fitogeografov iz novejšega obdobja (zadnja desetletja) kot so Nada Praprotnik (1987), Trinajstić (1976, 1986, 1995), ŠUgar (1984, 1995 s sodelavci), MARINČEK (1994), KošIR (1975) in Zupančıč s sodelavci $(1987,1995)$.

Prva usklajevalna dela za opredelitev in povezavo fitogeografskih območij s standardnimi rastlinskimi provincami smo zastavili že v devetdesetih letih prejšnjega stoletja (ZupANčıč et al. 1987, 1995). Temeljiteje smo se problemu posvetili v pričujoči razpravi.

Prva uskladitev Wrabrovin (1969) fitogeografskih območij s standardnimi rastlinskimi provincami je bila utemeljena predvsem na gozdni oziroma potencialno naravni vegetaciji in skromnejši floristični osnovi (Zupančič et al. 1987). Pri tem usklajevanju smo se srečevali z velikimi težavami, zlasti pri opredelitvi in razmejitvi $\mathrm{v}$ transalpinskem območju severovzhodne Slovenije (Prekmurje, Prlekija), kjer smo sicer predvideli poseben dravsko-murski distrikt. Poleg tega smo bili takrat prepričani, da so v Sloveniji zastopane štiri regije: poleg evrosibirsko-severnoameriške in alpsko-visokonordijske še mediteranska in panonsko-pontsko regija. Pri zadnji analizi (ŠUGAR et al. 1995) se je izkazalo, da zadnjih dveh regij v Sloveniji ni, saj za njiju ne moremo opredeliti ustreznih diagnostičnih vrst ali pa jih pri nas sploh ni (npr. za panonsko-pontsko regijo). Ugotavljamo pa, da je mediteranska zimzelena vegetacija oziroma flora le fragmentarno razvita na manjših površinah pri Ospu, Steni nad Dragonjo in na strunjanskem klifu.

V tej razpravi je upoštevan večji poudarek na floristični podlagi, to je razširjenosti vrst in izsledkih starejših avtorjev - fitogegrafov (Adamović, Beck, Hayek idr.). Naš namen je, da čim realneje, v povezavi z naravno geografskimi značilnostnimi, prikažemo fitogeografsko delitev Slovenije po rastlinskih provincah. Zlasti nas je zanimala razsežnost (obseg in zamejitev) ilirske florne province, ki je posebnost naše dežele: razteza se od jugovzhoda Balkanskega polotoka in se pri nas bolj ali manj končuje oziroma seže še nekoliko proti severovzhodu. 
Zdaj poznamo v Sloveniji 32 distriktov v šestih fitogeografskih območjih in pet rastlinskih provinc $\mathrm{v}$ dveh flornih regijah. Pojavljanje pete province - pre- norijsko-slovenske - predvidevamo za območje severovzhodne Slovenije in jo bomo izdvojili (razmejili) iz srednjeevropske province.

\section{POGOSTOST IN ZASTOPANOST RASTLINSKIH VRST V FITOGEOGRAFSKIH OBMOČJIH SLOVENIJE}

Slovenija je razdeljena na 6 fitogeografskih območij, in sicer na alpsko, predalpsko, dinarsko, preddinarsko, submediteransko in subpanonsko fitogeografsko območje (M. Wraber 1969). Nadgradnja fitogeografskih območij Slovenije je bila opredelitev nižjih fitogeografskih enot, kot so province, sektorji, podsektorji, in razdelitev na najnižje enote distrikte (Zupančıč et al. 1987, ZuPANČIČ \& ŽAGAR 1995). Zanimalo nas, je koliko rastlinskih vrst (vključno s podvrstami) raste izključno samo v enem fitogeografskem območju oziroma v posameznih distriktih različnih fitogeografskih območij.

Zdaj v Sloveniji beležimo od 3192 (JogAn et al. 2001) do okoli 3450 taksonov ali celo več (T. SELIŠKaR et al. 2003, Martinčič et al. 2007). Tu so upoštevani vsi taksoni (vključno s tujerodnimi), ne le avtohtone vrste. Za našo raziskavo smo uporabili objavljeni seznam in prikaz razširjenosti rastlinskih vrst JogANA in sodelavcev (2001), ki je že precej zastarel, tako po številu kot po poimenovanju taksonov. Glede aktualnega poimenovanja (in števila) taksonov smo uporabili rastlinski ključ (MartinčIČ et al. 2007) in podatkovno bazo FloVegSi (T. SELIŠKar et al. 2003, upoštevano je njeno stanje v letu 2018).

Vsako fitogeografsko območje ima nekaj posebnih rastlinskih vrst, ki uspevajo le $\mathrm{v}$ določenem fitogeografskem območju. Omenjeno naselitev določene rastline na le eno fitogeografsko območje pogojuje njena fitogeografska razširjenost skupaj s specifičnimi ekološkimi razmerami, kot so podnebje oziroma mezo- in mikroklima, geološka podlaga, relief, strani neba, nadmorska višina, morfologija terena, tla, kot tudi antropozoogeni vplivi in še kaj. Raziskava je pokazala, da sta floristično najbogatejši submediteranski in alpski fitogeografski območji. Vzrok je verjetno v izrazitih klimatskih in geološko-morfoloških razmerah. V alpskem fitogeografskem območju je hladna, precej namočena, alpsko-kontinentalna klima s pestrimi orografsko-reliefnimi oblikami. Submediteransko fitogegrafsko območje je toplo, manj namočeno, padavine so prisotne predvsem $\mathrm{v}$ jesenskem in deloma pomladanskem času, pogoste so poletne suše $\mathrm{z}$ redkimi ekstremno visokimi temperaturami. Svet je gričevnat, sicer reliefno bogato razčlenjen. Na obeh fitogeograf- skih območjih se izmenjujeta karbonatna in silikatna geološka podlaga. Pričakovali bi številne rastlinske posebnosti v subpanonskem območju, vendar nam je iz florističnih raziskav že znano, da je območje osiromašeno s panonsko-pontskimi vrstami. Pri nas ni izrazitega subpanonskega, kaj šele panonskega celinskega podnebja. Smo le na obrobju subpanonskega fitogeografskega območja, ki ga ne naseljujejo izrazite panonsko-pontske vrste. Posebnosti v evropskem merilu sta naši dinarski in preddinarski območji. Potekata od jugovzhoda do severozahoda, od Kolpe do Soče ob submediteranskem območju. Dinarsko območje je orografsko pestro, večinoma karbonatno, padavinsko podobno atlantskemu podnebju. Preddinarsko območje je prav tako večinoma karbonatno, gričevnato, s kontinentalno klimo. Območji sta floristično bogati, polni dinarsko-balkanskih florističnih posebnosti. Obe območji imata malo vrst, ki rastejo (uspevajo) izključno v dinarskem ali preddinarskem fitogegrafskem območju. Vzrok je tudi v medsebojnem dopolnjevanju areala dinarsko-balkanskih oziroma jugovzhodnoevropsko-ilirskih vrst med obema fitogeografskima območjima.

Veliko manj je rastlinskih vrst, ki bi uspevale izključno v distriktih. V nekaterih distriktih takih vrst sploh ni, npr. v nekaj distriktih preddinarskega fitogeografskega območja, kjer jih ni v treh od osmih distrikov, ali v alpskem območju, kjer jih je zelo malo $\mathrm{v}$ treh od devetih distriktov, ali v dinarskem območju, kjer jih ni v enem od štirih distriktov. Distrikti v drugih fitogeografskih območjih so bolj ali manj bogati s sebi lastnimi rastlinskimi vrstami. Floristično najbogatejši so koprsko-šavrinski (180), ptujski (dravsko-murski) (58), kraško-vipavski (57), kranjski (48) in štajersko-koroški (37) distrikt.

Kaj pomeni številčnost vrst na posameznih fitogeografskih območjih oziroma v njihovih distriktih?

Bogastvo flore na posameznih fitogeografskih območjih oziroma v njihovih distriktih zagotovo pomeni ali potrjuje, da so te fitogeografske enote upravičene in dobro izbrane, nakazuje njihovo floristično in ekolo- 
ško posebnost. Te vrste bi lahko uvrstili med diagnostično pomembne vrste ali celo med značilnice ali razlikovalnice kot dopolnilo $\mathrm{k}$ že izbranim ali uveljavljenim značilnicam določenega fitogeografskega območja. Alpsko fitogeografsko območje prepoznamo po njegovih posebnih alpskih hladnoljubnih vrstah, kot so npr. absolutni endemiti Campanula $x$ vrtacensis, $P$. alpinum subsp. victoris, Nigritella kosutensis in N. ravnikii ali subendmiti oz. relativni endemiti npr. A. tauricum nsubsp. hayekianum, A. tauricum subsp. tauricum, A. tauricum subsp. latemarense, Campanula zoysii, Cerastium julicum, Festuca calva, F. laxa, Gentiana froelichii, Heracleum austriacum subsp. siifolium, Leucanthemum lithopolitanicum, Nigritella lithopolitanica, N. widderi, N. archiducis-joannis, Papaver alpinum subsp. ernesti-mayeri, Pedicularis elongata subsp. julica, Saxifraga hohenwartii, Scorzoneroides crocea ipd.

Naš submediteran zaznamujejo toploljubne submediteranske in mediteranske vrste, ki jih ni v drugih fitogeografskih območjih, npr. Asparagus acutifolius, Cistus salviifolius, Colutea arborescens, Coronilla cretica, Euphrasia marchesettii, Osyris alba, Rubia peregrina, Smilax aspera, Viburnum tinus, ali pa so pri nas razmeroma redke, kot so: Celtis australis, Pistacia terebinthus in Quercus ilex. Poleg naštetih vrst se v našem submediteranskem območju pojavljajo še nekateri (sub)endemiti, in sicer: Alyssum montanum subsp. montanum, Campunula marchesettii, Hieracium dragicola, Knautia drymeia subsp. tergestina, Moehringia tommasinii, Ranunculus pospichalii idr.

Dinarsko fitogeografsko območje je floristično bogato, vendar skromno glede posebnosti oziroma izključno ali večinoma na tem območju rastočimi vrstami. Tu uspevajo nekateri naši endemiti, in sicer Hladnikia pastinacifolia, Primula carniolica s križancem Primula $\mathrm{x}$ venusta in Ranunculus wraberi. $\mathrm{Z}$ jugovzhoda pa $\mathrm{k}$ nam prihajajo dinarsko-balkanske vrste, ki se pojavljajo izključno le v dinarskem območju, in sicer: Cerastium dinaricum, Edraianthus graminifolius, Festuca bosniaca, Helianthemum rupifragum, Polygala croatica, Thymus balcanus, ki z endemiti odlično opredeljujejo naše dinarsko fitogeografsko območje.

Subpanonsko fitogeografsko območje v Sloveniji, ki je na skrajnem zahodnem subpanonskem obrobju, nima izrazitih panonsko-pontskih vrst. Večinoma so to splošno razširjene vrste panonskega območja, ki se večinoma ne pojavljajo $\mathrm{v}$ drugih fitogeografskih območjih, in sicer: Daphne cneorum subsp. arbusculoides, Epipactis nordeniorum, Gagea spathacea, Moenchia mantica subsp. caerulea, Myosotis laxa, Papaver dubium, Potentilla supina, Pulmonaria mollis, Pulsatilla grandis, Veronica triphyllos, Viscum laxum idr. V su- bpanonskem fitogeografskem območju se nekatere splošno razširjene vrste pogosteje in bolj množično pojavljajo kot v drugih fitogeografskih območjih Slovenije, s čimer dajejo določen pečat našemu predpanonskem območju, in sicer: Chenopodium rubrum, Cynosurus echinatus, Epipactis voethii, Omphalodes scorpioides, Scirpus radicans, Trifolium pannonicum idr.

Reka Mura in njeni pritoki so ustvarili mrtve rokave, mrtvice, stoječo vodo, ponekod so nastala umetna jezera zaradi opuščanja peskokopov ali pa so ustvarili ribnike, od katerih so posamezni sedaj opuščeni. Na teh vodnih površinah se pojavlja posebna brežinska, močvirna ali vodna flora, tipična za naše subpanonsko fitogeografsko območje. Naj navedemo nekaj rastlin: Carex bohemica, Cyperus michelianus, Montia fontana, Marsilea quadrifolia, Nymphoides peltata, Potamogeton obtusifolius, Typha minima, Wolffia arrhiza. Nekatere vrste se na ekološko podobnih vodnih rastiščih pojavljajo tudi drugod, v drugih fitogeografskih območjih, vendar so v subpanonskem območju pogostejše in stalnejše: Cyperus glomeratus, Lemna trisulca, Scirpus radicans, Typha laxmanii idr. Navedene vrste lahko štejemo kot bolj ali manj diagnostične vrste našega subpanonskega fitogeografskega območja.

Predalpsko fitogeografsko območje ni tako bogato kot alpsko z rastlinskimi vrstami, ki bi uspevale izključno v njem. Prisotnih je le nekaj zanimivih rastlin, med njimi so endemiti Leontodon berinii, Moehringia villosa, Ranunculus thora f. pseudoscutatus, $R$. aesotinus, Saxifraga paradoxa, ali zavarovane vrste, Gladiolus imbricatus, Daphne cneorum subsp. cneorum, Liparis loeselii, Lycopodiella inundata idr. Poleg naštetih so zanimive še vrste Cirsium waldsteinii, Diphasiastrum alpinum, Euphorbia triflora subsp. kerneri, Poa carniolica, Primula veris subsp. canescens, Woodsia ilvensis, ki jih lahko bolj ali manj zanesljivo uvrščamo med diagnostično pomembne vrste našega predalpskega fitogeografskega območja. Večina naštetih vrst prihaja $\mathrm{k}$ nam z zahoda.

Preddinarsko fitogeografsko območje je najrevnejše z izključnimi rastlinskimi vrstami, čeprav je floristično bogato. Manjši izbor flore vendarle zaznamuje to fitogeografsko območje, kljub temu, da nekatere od navedenih vrst posamično uspevajo $\mathrm{v}$ dinarskem, submediteranskem ali celo predalpskem fitogeografskem območju. Stalne, izključno ali večinoma na preddinarskem fitogeografskem območju rastoče vrste so: Acer obtusatum, Aconitum variegatum subsp. nasutum, A. vitosanum, Asplenium trichomanes subsp. pachyrhachis, Dianthus giganteus subsp. croaticus, Erysimum carniolicum, Fumaria officinalis subsp. wirtgenii in Rosa blondaeana. 
Večina distriktov fitogeografskih območij ima svoje sebi lastne rastoče vrste, kar je razvidno iz Tabel 1 in 2. Vendar jih nekateri distrikti nimajo ali jih imajo zelo malo: takšni so jugovzhodnoalpski in primorsko-julijskoalpski distrikt $\mathrm{v}$ alpskem fitogeografskem območju, krimsko-mokriško-goteniški distrikt $\mathrm{v}$ dinarskem fitogeografskem območju ter zahodnodolenjski, notranjski, polhograjski, iški, bohorsko-kumski in osrednjedolenjski distrikt $\mathrm{v}$ preddinarskem fitogeografskem območju. $V$ te distrikte pa prihajajo vrste iz drugih fitogeografskih območij, ki bi jih tu ne pričakovali. Tako dajejo tem distriktom določen floristični in ekološki pečat oziroma drugačnost, kar opravičuje njihov obstoj. Očiten primer je iški distrikt, v katerem so nekatere alpske in številne dinarske vrste. Alpske vrste označujejo posebnost distrikta. Zaradi prisotnosti dinarskih vrst pa ni jasno, ali ga naj uvrstimo v preddinarsko (ZupANČIČ \& ŽAGAR 1995) ali kar v dinarsko fitogeografsko območje, kamor ga uvršča AсCETto (2010).

Za fitogeografska območja in distrikte smo izdelali analizo rastlinskih vrst, ki izključno ali večinoma uspevajo v določenem fitogeografskem območju, in jih opredelili glede na biološke oblike in njihove fitogeografske razširjenosti (po geoelementih) ter to prikazali v tabelah 3-20. Tako izbrane rastlinske vrste odražajo določeno floristično in ekološko podobo posameznega distrikta, skupek rastlinstva distriktov v določenem fitogeografskem območju pa posledično prikazuje njegovo floristično in ekološko podobo (Tabele 21-24). Za opredelitev bioloških oblik in geoelementov smo uporabljali literaturo Pignattija (2005), deloma Aeschimanna et al. (2004) in v manjši meri Poldinija (1991).

Analiza izključno ali večinoma prisotnih vrst alpskega fitogeografskega območja (Tabele 3, 4 in 5) kaže na prevlado hemikriptofitov ( 25 oz. $56 \%$ ), njim sledijo hamefiti (7 oz. $18 \%)$ in nato geofiti (5 oz. $13 \%)$, terofitov je zanemerljivo malo (1 oz. $3 \%)$. Med izključne ali večinoma prisotne vrste se niso uvrstili fanerofiti s. lat., helofiti in hidrofiti (Tabela 22). V primerjavi z drugimi fitogeografskimi enotami po deležu udeležbe hemokriptofitov s hamefiti zasedajo tretje mesto (Tabela 21). Tabela 24 prikazuje razmerja med geoelementi alpskega območja, kjer prevladujejo endemiti $(8 \mathrm{oz}$. $22 \%$ ) in alpski endemiti (5 oz. $14 \%$ ). Drugi geoelementi s prej omenjenimi enotami kažejo na hladne alpske razmere v jugovzhodnem območju Alp. V primerjavi z drugimi fitogeografskimi območji Slovenije (Tabela 23) izstopajo v alpskem območju alpski endemiti $(5 \mathrm{oz}$. 62 \%): Jovibarba arenaria, Artemisia genipi, Minuartia rupestris, Primula villosa, Taraxacum cuculatum in vzhodnoalpsko-ilirski endemit Viola zoysii, ter ostali endemiti značilni za jugovzhodne Apneniške Alpe: Androsace helvetica, A. hausmanii, Papaver alpinum subsp. victoris, Festuca alpestris, Geranium argenteum, Poa cenisia idr. Alpsko območje je poleg predalpskega in submediteranskega območja bogato $\mathrm{z}$ endemiti. Iz Tabele 23 je razvidno pojavljanje drugih geoelementov, ki so v primerjavi z drugimi območji, zlasti predalpskim območjem, številčno manj prisotni, kažejo pa na prej omenjene hladne alpske razmere.

Najbolj floristično podprt z izključno ali večinoma rastočimi vrstami je jugovzhodnoalpski distrikt (2 a), slabo pa alpsko-pohorski (1d) in primorsko- julijskoalpski distrikt (2d), kar pa ne pomeni, da nimata svojih posebnosti v ožjem in širšem krogu fitogeografske delitve Slovenije (Tabele 3, 4 in 5). Predvsem se od drugih distriktov razlikujeta zaradi toplotnega vpliva panonskega podnebja (alpsko-pohorski distrikt (1 d), oziroma sredozemskega podnebja (primorsko-julijskoalpski distrikt (2 d)), ki omogoča pojavljanje nekaterih toploljubnih rastlinskih vrst, ki so sicer splošno razširjene v subpanonskem in submediteranskem območju in tu niso izključno ali večinoma prisotne.

Analiza izključno ali večinoma prisotnih vrst predalpskega fitogeografskega območja (Tabele 6, 7 in 8) kaže na visoko prevlado hemikriptofitov (65 oz. 49 \%). Številčni so tudi terofiti ( 25 oz. $19 \%$ ) in geofiti (19 oz. $14 \%$ ). Za razliko od alpskega območja se med izključno ali večinoma prisotnimi vrstami pojavljajo fanerofiti (8 oz. $6 \%$ ) in nanofanerofit ( 1 oz. $1 \%)$. Nekaj je tudi hamefitov (9 oz. $6 \%$ ). Prisotna sta še helofita in hidrofita (vsak po 2 oz. 2-3 \%) (Tabela 22). Razpored vrst po biološki obliki v primerjavi z drugimi fitogeografskimi območji (Tabela 21) kaže, da je predalpsko območje bogato $s$ hemikriptofiti podobno kot submediteransko (65 oz. $33 \%$ ); številčno ga presega tudi v drugih bioloških oblikah, razen v primerjavi s submediteranskem območjem, ki je na splošno bogatejše po raznovrstnosti bioloških oblik. Razpored vrst po bioloških oblikah kaže na zmernejše življenjske razmere, ki se odražajo tudi v prisotnosti terofitov in fanerofitov. Primerjava geoelementov $\mathrm{z}$ alpskim fitogeografskim območjem kaže na določeno podobnost in hkrati določeno raznolikost, ki je svojska zaradi prisotnosti redkih posamičnih vrst. Nekateri geoelementi so celo manjšinsko zastopani v primerjavi z drugimi območji, vendar dajo določen fitogeografski pečat, kot sta stenomediteranski in jugovznodnoevropski geoelement. (Tabela 24). Posebnost predalpskega območja je prisotnost endemitov $(7 \mathrm{oz}$. $6 \%)$ oz. alpskih endemitov (2 oz. $2 \%$ ) v dolinah ali v višjih legah predalpskega območja. Ti so: Euphorbia kerneri, Leontodon berinii, L. hispidus subsp. brumatii, Polygala croatica, Gentianella aspera, Thesium ro- 
stratum in Jovibarba hirta. Primerjavo geoelemtnov znotraj predalpskega območja prikazuje Tabela 24, kjer prevladujejo geoelementi evropsko-vzhodnoevropskega območja $\mathrm{z}$ vdorom sredozemskih in vzhodnih - (azijskih) geoelementov. Vsi distrikti (4a do 4d) so dobro floristično podprti.

Analiza izključno ali večinoma prisotnih vrst dinarskega fitogeografskega območja (Tabele 9,10 in 11) kaže, da v njem prevladujejo hemikriptofiti $(17 \mathrm{oz} .58$ \%). Skromno so zastopani terofiti (5 oz. $14 \%$ ), fanerofiti (5 oz. 17 \%) ter hamefiti (3 oz. 9 \%) (Tabela 22). V primerjavi z drugimi območji vidimo skromno zastopanost izključnih vrst $\mathrm{v}$ dinarskem območju in zato je tudi skromna zastopanost teh vrst v posameznih kategorijah bioloških oblik (Tabela 21). Primerjava bioloških oblik z drugimi območji nam ne daje podobe življenjskih razmer v dinarskem območju. Opremo se lahko le na primerjavo znotraj območja, kjer prevlada hemikriptofitov daje podobo težjih, a ne pretežkih rastiščnih razmer.

Pestrost geoelementov v dinarskem območju je skromna, endemitov je malo,kot sta npr. Hladnikia pastinacifolia in Ranunculus wraberi. $\mathrm{Z}$ dvema vrstama so zastopani orof. jugovzhodnoevropski, evropsko-azijski in mediteranski geoelement, drugi so zastopani le $\mathrm{z}$ eno vrsto (Tabela 24). V primerjavi z drugimi območji so tu zastopani jugozahodni, orof. centralnoevropski in mediteransko-zahodnoazijski geoelementi. Posebnost je prisotnost 16 vrst ilirskega geoelementa (Tabela 23). Razpored po geoelementih kaže, da dinarsko območje pripada evropsko-južnoevropskemu prostoru.

Z izključno ali večinoma prisotnomi vrstami so podprti distrikti $5 \mathrm{a}, \mathrm{b}$ in $\mathrm{d}$. Zelo malo izključnih vrst imata mokrško-goteniški in krimski distikt in nista floristično niti vegetacijsko podprta. Smiselno ju je bilo združiti in preimenovati v krimsko-mokriško-goteniški distrikt (5d).

Po mnenju Dakskoblerja (2015) je uvrščanje Banjšic v trnovski distrikt (5a) vprašljivo, saj je območje prehodno med submediteranskim in predalpskim fitogeografskim območjem (KaLIGARIČ \& ŠKORNIK 2002).

Izključno ali večinoma prisotnih vrst $\mathrm{v}$ preddinarskem fitogeografskem območju je še manj kot v dinarskem območju (Tabele 12, 13 in 14). Obe območji sta floristično skladni z jugovzhodnoevropsko-ilirskimi vrstami, ki se po številu in množičnosti pojavljajo $\mathrm{v}$ obeh območjih in se tako izključujejo kot izključne ali večinoma prisotne vrste $\mathrm{v}$ prvem ali drugem območju. Kot v dinarskem območju se tudi v preddinarskem območju pojavljajo predvsem hemikriptofiti (4 oz. $44 \%$ ). Opazni so tudi fanerofiti in terofiti (z 2 vrstama oz. 22
\%). Tu ni izključnih vrst helofitov in hidrofitov (Tabela 22). V primerjavi $z$ drugimi območji je to območje najrevnejše z izključno ali večinoma prisotnimi vrstami, kar ima za posledico skromen delež bioloških oblik (Tabela 21). Težko bi ovrednotili življenjske razmere na podlagi bioloških oblik. Odstotni delež geoelementov je v preddinarskem območju enakomeren (Tabela 24). $\mathrm{V}$ primerjavi z drugimi območji izstopata le dva geoelementa, ki jih v drugih območjih ni, in sicer jugozahodnoevropski in mediteransko-azijski geoelement. Drugi geoelementi, ki so večinoma prisotni v dinarskem območju, dajejo toplotni pečat južne-jugovzhodne Evrope (Tabela 23). Glede na skromnost vrst v kategorijah življenjskih oblik in geoelementov lahko $\mathrm{z}$ zadržkom sklepamo o ugodnih vegetacijskih življenjskih razmerah preddinarskega območja.

Od 8 distriktov v preddinarskem območju so le $\mathrm{v}$ petih distriktih prisotne, a maloštevilne izključne ali večinoma prisotne vrste (Tabele 12, 13 in 14). Iz floristične in vegetacijske analize ZuPANČIČA in ŽAGARJA (1995) pa je upravičena delitev na 8 distriktov.

Submediteransko fitogeografsko območje je najbogatejše z izključno ali večinoma prisotnimi vrstami (Tabele 15, 16 in 17). Analiza bioloških oblik je bolj ali manj uravnotežena - z izjemo, da ni helofitov. Prevladujoče so štiri kategorije: številni terofiti (115 oz. 44 $\%)$, nato hemikriptofiti (67 oz. $26 \%$ ), sledijo geofiti (28 oz. $11 \%$ ) in fanerofiti ( $28 \mathrm{oz} .11 \%)$. Manj so zastopani hamefiti (13 oz. $5 \%$ ) in hidrofiti ( 8 oz. $3 \%$ ) (Tabela 22$)$. Razpored oz. delež vrst po bioloških oblikah v primerjavi z drugimi območji kaže naslednjo podobo: terofitov je $66 \%$, fanerofitov $61 \%$, nanofanerofitov $56 \%$, geofitov $45 \%$, hidrofitov $44 \%$, hamefitov $35 \%$ in hemikriptofitov $34 \%$. Primerjava med območji kaže, da je submediteransko območje $\mathrm{v}$ vseh kategorijah, razen pri heliofitih, vodilno. Velika zastopanost terofitov in fanerofitov s. lat. poudarjajo tople sušne submediteranske razmere. Geofiti se pojavljajo le spomladi, sušo pa prežive s podzemnimi rastlinskimi organi. Na neugodne sezonske razmere nakazujejo številni hemikriptofiti. (Tabeli 21 in 22).

Submediteransko fitogeografsko območje je bogato $\mathrm{z}$ izključnimi ali večinoma prisotnimi geoelementi, ki izkazujejo tople klimatske razmere in so skladni z razporedom bioloških oblik. Fitogeografski položaj območja lahko sintezno predstavimo kot evropsko-mediteranski z vplivi iz Atlantika na zahodu in toplega dela celine na vzhodu (Tabela 24).

Vsi distrikti submediteranskega območja so floristično ovrednoteni. Največ izključnih ali večinoma prisotnih vrst imata kraško-vipavski (7 b) in koprsko-šavrinski distrikt (7 d). Najmanj izključnih ali večinoma prisotnih vrst je $\mathrm{v}$ briškem $(7 \mathrm{a})$ in brkinskem (7 c) 
distriktu. Najbolj topel in sušen mediteranski je koprsko-šavrinski distrikt (7 d), kar se odraža v številnih vrstah terofitov ter stenomediteranskih, evromediteranskih in manj številnih subtropskih geoelementov (Tabela 15). Na jugovzhodni vpliv pa lahko sklepamo po zmerni zastopanosti evromediteranskih-turanskih in jugovzhodnih-južnosibirskih ter podobnih številčno manj prisotnih geoelementov. Med izključnimi vrstami je prisoten endemit Moehringia tommasinii (Tabeli 16 in 17).

Zanimivo je, da je v kraško-vipavskem distriktu (7 b) med izključnimi vrstami 5 endemitov: Hieracium dragicola, Moehringia tommasinii, Sorbus istriaca, S. mayeri in S. slavnicensis, kar daje distriktu svojski pečat, s tem pa tudi slovenskemu in severnojadranskemu submediteranu (Tabeli 15 in 17).

Analiza izključno ali večinoma prisotnih vrst v subpanonskem fitogeografskem območju (Tabele 18, 19 in 20) kaže, da so v njem najštevilčnejši terofiti (26 oz. $41 \%$ ) in nato hemikriptofiti (17 oz. $27 \%$ ). Poleg terofitov, ki označujejo "stepsko« območje, so za naše obrobje subpanonije značilni še hidrofiti (7 oz. 11 \%), ki so naselili mokrišča, mrtve rokave reke Mure ali poplavljene opuščene peskokope ipd. (Tabela 22). V primerjavi z drugimi območji v subpanonskem območju izstopajo hidrofiti (7 oz. $39 \%$ ), podobno kot v submediteranskem območju (8 oz. $44 \%$ ). Odstotne udeležbe vrst drugih bioloških oblik so nekoliko podobne predalpskemu območju; te so tu bolje zastopane kot v alpskem, dinarskem in preddinarskem območju. (Tabela 21). Skladno z deležem bioloških oblik v subpanonskem fitogeografskem območju ugotavljamo, da so rastne razmere vegetacije relativno ugodne glede večjega pojavljanja terofitov in nanofanerofitov. Ti kažejo na toplo podnebje, kar pa je lahko ob pretirano vročih obdobjih tudi neugodno zaradi suše.

Pojavljanje izključnih geoelementov v subpanonskem območju je skromno in posamično (6 vrst, po en podatek oz. primerek, Tabela 23). Drugi geoelementi so skladni s submediteranskim območjem in redke uvrščamo med "večinoma prisotne«. Najpogosteje so geoelementi zastopani le $\mathrm{z}$ eno vrsto. $\mathrm{V}$ haloškem distriktu (3b) je zabeležena zavarovana vrsta - endemit Sempervivum juvanii (Donačka gora - kremenčevo-apnenčev peščenjak in konglomerat). Analiza geoelementov kaže jugovzhodnoevropski-evropski-vzhodnoevropsko-karpatsko-azijski značaj. (Tabela 24). Na to opredelitev lahko sklepamo iz Tabele 23, ki kaže odstotni delež geoelementov v primerjavi z drugimi fitogeografskimi območji.

Vsi trije distrikti subpanonskega fitogeografskega območja so floristično podprti (Tabele 18 - 20), zlasti še ptujski (dravsko-murski) (3a), ki ga predlagamo v prenorijsko-slovensko floristično provinco (MEUSEL et al. 1965) kot ptujski distrikt (Soó 1961). Po številu vrst je ta distrikt najbolj panonski (»stepski«) s številnimi terofiti in vzhodnimi geoelementi. Izbrane (izključne ali večinoma prisotne) vrste tega distrikta glede na biološke oblike (Tabela 19) uvrščamo predvsem v terofite, ki jih je 24 (46\%), in hemikriptofite, ki jih je 10 (19 $\%)$. Zaradi mrtvic, bajerjev (ribnikov), ki so nastali iz opuščenih peskokopov in jih je sčasoma zalila voda, ter drugih mokrišč se pojavlja $6(12 \%)$ hidrofitov. Prav toliko je geofitov 6 (12\%). Hamefiti so 3 (6\%). Redki so nanofanerofiti 2 (4\%) in fanerofiti 2 (1\%). Pravo podobo fitogeografskega območja oziroma floristične province dajo terofiti, ki so vodilni za nižinsko, poljedeljsko subpanonsko območje ali - natančneje - za obrobje subpanonskega območja Slovenije. Poleg terofitov so za obravnavano območje in posledično tudi za ptujski distrikt prenorijsko-slovenske floristične province značilni hidrofiti, ki naseljujejo številna tamkajšnja mokrišča (Tabela 19).

Opredelitev izključnih ali večinoma prisotnih vrst po fitogeografski razširjenosti (Tabela 20) je naslednja. Največ je evroazijskih (8 oz. $15 \%$ ), subkozmopolitskih (6 oz. $11 \%$ ), evrosibirskih (5 oz. $10 \%$ ), južnoevropsko-južnosibirskih (5 oz. $10 \%$ ), subtropskih (4 oz. $8 \%$ ) in južnoevropskih ( 3 oz. $6 \%$ ) geoelementov. To je polovica vseh izključnih ali večinoma prisotnih vrst, ki fitogeografsko dobro opredeljujejo ptujski distrikt prenorijsko-slovenske province našega severovzhodnega obrobnega subpanonskega območja. K tem diagnostičnim vrstam ptujskega distrikta bi dodali še manj zastopane geoelemente, kot so: vzhodnoevropski (2 oz. 4 \%), pontski, paleosubtropski, cirkumborealni, stenomediteranski, severnomediteransko-montanski, evromediteransko-turanski, jugovzhodnocentralno-evropski, evropsko-kavkaški, vzhodnomediteranski in paleotemperatni geoelement (vsi zastopani z 1 vrsto oz. $2 \%$ ). Drugi geoelementi v Tabeli 20 so prisotni še v drugih distriktih.

Naredili smo še analizo pojavljanja jugovzhodnoevropsko-ilirskih elementov v ptujskem distriktu, da bi spoznali vpliv sosednje ilirske province na južni in jugozahodni meji, to je z bizeljsko-krškim (3c) in štajersko-koroškim distriktom (4c). Od jugovzhodnoevropsko-ilirskih geoelementov je $\mathrm{z}$ ožjo razširjenostjo večinoma prisotna le vrsta Aposeris foetida in s širšo razširjenostjo vrsti Knautia drymeia subsp. drymeia in Fraxinus angustifolia subsp. oxycarpa. Od ožje razširjenih jugovzhodnoevropsko-ilirskih vrst so na zahodnem stičnem območju redko ali zelo redko prisotne naslednje vrste: Anemone trifolia, Cardamine trifolia, C. enneaphyllos, C. waldsteinii in Aremonia agrimonioides, na južnem stičnem območju pa vrste: Hacquetia 
epipactis, Hieracium transsilvanicum in Festuca drymeia; po vsem območju pa so raztresene vrste $L a$ mium orvala, Polystichum setiferum, Erythronium dens-canis in Tamus communis. Večina naštetih vrst bolje uspeva na bazičnih tleh in karbonatni geološki podlagi, izjemi sta vrsti Erhythronium dens-canis in Hieracium transsilvanicum, ki uspevata na kislih tleh, ter vrsti Festuca drymeia in Polystichum setiferum, ki sta prilagodljivi in uspevata tudi na zmerno kislih do bazičnih tleh.

Posamično, redko pojavljanje jugovzhodnoevropsko-ilirskih vrst in bolj pogosti, ne tako diagnostično pomembni jugovzhodnoevropsko-ilirski vrsti Aposeris foetida in Knautia drymeia subsp. drymeia skupaj kažeta na določeno diferenciacijo ptujskega distrikta znotraj prenorijsko-slovenske province. Posebej dobro jo označuje vrsta Fraxinus angustifolia subsp. oxycar$p a$, ki je prisotna izključno $\mathrm{v}$ slovenskem subpanonskem obrobju.

Floristični analizi ptujskega distrikta prenorijsko-slovenske province sledi vegetacijska analiza gozdnih združb, ki so značilne zanjo in večinoma ali povsem razširjene zgolj tu. Te so: Vicio oroboidi-Fagetum (Ht. 1938), Pocs \& Borhidi in Borhidi 1960, Polysticho setiferi-Fagetum Zupančič et al. 2001 (non Ubaldi 1988 nom. inv.), Festuco drymeiae-Abietetum
Vukelić \& Baričević 2007, Pruno padi-Carpinetum betuli (Marinček \& Zupančič 1982), Marinček 1994, Hieracio rotundati-Fagetum Ž. Košir 1994, Galio rotundifolii-Pinetum Zupančič \& Čarni ex Čarni et al.1992, Pruno padi-Fraxinetum angustifoliae Čarni et al. 2008 nom. nud., Fraxino-Ulmetum effusae Slavnić 1952 var. Prunus padus Vukelić et Baričević 2004, Salicetum albae-fragilis Soó (1930) 1940, Querco roboris-Carpinetum M.Wraber 1969, Stellario nemorum-Alnetum glutinosae Lohmayer (1953) 1957, Lonicero caprifolii-Quercetum roboris (Rauš 1971) Marinček 1994 in Querco roboris-Ulmetum minoris Issler 1924. Od traviščnih združb bi bila za to območje značilna (tu prvikrat opisana) združba Dactylis glomerata-Festuca pratensis comm. (A. Seliškar 1998) ter pozneje spoznana suha ali polsuha travišča subpanonskega sveta Slovenije Hypochoerido-Festucetum rupicolae Steinbuch 1995 in Onobrychido viciifoliae-Brometum Kaligarič et Škornik 2002 (Kaligarič \& ŠKoRNiK 2002, ŠKoRnik 2003). Kot smo že zapisali, so na obravnavanem območju številna mokrišča, ki jih porašča več (devet) mokriščnih združb razredov Lemnetea, Isoeto-Nanojuncetea, Galio-Urticetea in Phragmiti-Magnocaricetea, ki dajejo svojski pečat pokrajini in s tem tudi ptujskem distriktu ter prenorijsko-slovenski provinci.

\section{PRIMERJAVA MED ANALIZAMA IZBRANIH IN VSEH TAKSONOV V FITOGEOGRAFSKIH OBMOČJIH SLOVENIJE}

Za primerjavo smo naredili analizo bioloških oblik taksonov med izključno ali večinoma prisotnimi (izbranimi) in vsemi rastočimi vrstami Slovenije v posameznih fitogeografskih območjih po M. WraBRU (1969) v želji, da bi ugotovili skladnost ali različnost rezultatov razmerij med biološkimi oblikami. V obdelavo po programu FloVegSi (T. SelišKar et al. 2003) je bilo zajetih 3240 taksonov (Diagrama 1 in 2).

V alpskem fitogeografskem območju so razmerja bioloških oblik večinoma bolj ali manj skladna. (Tabela 22, Diagram 1). Razlika je pri fanerofitih, ki pri analizi izključnih ali večinoma prisotnih vrst umanjkajo (Tabela 22). To si razlagamo tako, da se tu prisotne drevesne vrste (npr. macesen, smreka, jelka, bukev, beli javor idr.) pojavljajo tudi v drugih fitogeografskih območjih. Preseneča pa nas številčnost terofitov za alpsko območje (Diagram 1), kjer nismo pričakovali tako visokega deleža. Razlago za tak rezultat pripisujemo preširoko oblikovanemu alpskemu območju $M$. WrABRA (1969) v smeri proti nižjemu predalpskemu območju.
V predalpskem fitogeografskem območju sta obe analizi razporeda bioloških oblik skladni z zanemarljivimi odstopanji.

Primerjava bioloških vrst $\mathbf{v}$ dinarskem fitogeografskem območju je skladna. Razlika je le v pojavljanju števila fanerofitov, kjer je kar 15:6 (Tabela 22, Diagrama 1 in 2). Dinarsko območje je poznano po različnosti drevesnih (fanerofitov) in grmovnih vrst (nanofanerofitov). Razliko si razlagamo z nenatančnima metodama, ki sta $\mathrm{v}$ danih primerih zastavljeni na približkih in zato relativni, vendar dajeta zadovoljiv rezultat.

V preddinarskem fitogeografskem območju se med analizama izbranih in vseh vrst v Sloveniji razlikuje odstotek fanerofitov za skoraj enkrat več, minimalno je odstopanje pri hamefitih (Tabela 22, Diagrama 1 in 2). Razmerja pri drugih bioloških oblikah so skladna. V razmerjih fanerofitov in hamefitov med obema analizama gre verjeti analizi, ki zajema vse rastlinstvo Slovenije. Ugotavljamo, da se pri izbranih vrstah lahko pojavi napaka zaradi obravnave manjšega 
števila vrst, ki pridejo v poštev. Vprašanje je, zakaj so pri analizi izbranih vrst izpadli hamefiti.

Pri submediteranskem fitogeografskem območju so odstotna razhajanja pri hemikriptofitih in terofitih. Enkrat več je hemikriptofitov v analizi vseh vrst $\mathrm{v}$ Sloveniji in enkrat več je terofitov v analizi izbirnih vrst. Drugi odstotki bioloških vrst so skladni. Vzrok je verjetno v relativnosti obeh analiz, kjer ne moremo natančno opredeliti meje območij pri eni ali drugi analizi. (Tabela 22, Diagram 1).

V subpanonskem fitogeografskem območju je največ razlik. $V$ analizi vseh vrst v Sloveniji prevladujejo fanerofiti in hemikriptofiti; geofiti in terofiti pa $v$ analizi izbranih vrst (Tabela 22, Diagram 1). Analiza vseh vrst je zaradi popolnosti bolj zanesljiva in tudi računalniško podprta. Kljub razlikam med analizama ugotavljamo, da so razmerja med biološkimi oblikami zelo podobna. $\mathrm{V}$ obeh analizah prevladujejo hemikriptofiti in terofiti, kar je značilno za subpanonsko območje. V primerjavi z drugimi fitogeografskimi območji so v subpanonskem območju v obeh analizah odstotno najvišje zastopani hidrofiti (Tabela 22, Diagram 1). V podobni primerjavi za fanerofite ugotavljamo, da so odstotki na vseh območjih uravnoteženi (Diagram 1). Analiza izbranih vrst po območjih kaže podpovprečno odstotnost fanerofitov v subpanonskem območju, kar ni realno. Razlog je podoben kot $\mathrm{v}$ drugih fitogeografskih območjih, saj so skoraj vsi fanerofiti večinoma prisotni v vseh fitogeografskih območjih.

Ugotavljamo, da analiza bioloških oblik vseh vrst večinoma potrjuje analizo izbranih (izključnih in večinoma prisotnih) vrst, ki zvesto odseva njihove življenjske razmere, tako za posamezne taksone kot za vzajemno rast $\mathrm{v}$ različnih vegetacijskih oblikah.

\section{DELITEV SLOVENIJE NA FLORNE PROVINCE}

Slovenija je razdeljena na dve fitogeografski regiji: na površinsko najbolj razširjeno evrosibirsko-severnoameriško regijo in po površini skromno zastopano alpsko-nordijsko regijo $\mathrm{v}$ severozahodnem alpskem svetu. V sklopu teh dveh regij imamo pet fitogeografskih provinc. V evrosibirsko-severnoameriški regiji so štiri: srednjeevropska na manjšem območju severne Slovenije, ilirska v osrednji Sloveniji ima največjo površino in ilirskojadranska provinca na manjšem območju jugozahodne Slovenije in na severovzhodu na novo izločena prenorijsko-slovenska provinca $\mathrm{z}$ manjšo razširjenostjo. Fitogeografsko posebni sta ilirska in ilirskojadranska provinca, ki se razlikujeta od srednjeevropske in prenorijsko-slovenske province $\mathrm{z}$ jugovzhodnoevropskoilirskimi (ilirskimi, ilirikoidnimi) geoelementi, večinoma prihajajočimi z Balkanskega polotoka, ki pri nas proti zahodu dosežejo skrajno mejo svojega areala. V alpsko-nordijski regiji imamo alpsko provinco, ki jo naseljujejo jugovzhodnoalpski geoelementi z zahoda, pri nas pa dosegajo najvzhodnejšo poselitev.

Pri opisu novih distriktov Slovenije (Zupančič \& ŽAGAR 1995) smo razmišljali tudi o problemu razširjenosti ilirske florne province. Osnovna razmišljanja so izhajala iz temeljnih raziskav starejših avtorjev $\mathrm{v}$ začetku dvajsetega stoletja (Zupančič \& ŽAGAR 1995: 21). Opirali smo se na AdAMOvićev (1906) kartografski prikaz ilirske florne province, predvsem pa na temeljne študije Becka $(1907,1908,1913)$ in HaYeka $(1907$, 1923). BЕCK (1907-1913) loči v svoji študiji mediteransko, ilirsko in srednjeevropsko floro, kar je solidna osnova za razmejitev današnje ilirskojadranske, ilirske in srednjeevropske province. HAYEK (1907) se je osredotočil predvsem na alpsko območje - Kamniške planine, ki jih deli na šest pasov: gorsko (montanski) pas, 340-700 m (900 m), spodnje predalpsko, ((700 m) 900$1200 \mathrm{~m})$, zgornje predalspko območje (1300-1628 m), območje ruševja (1631-1802 m), alpsko (2020-2250m) in subnivalno območje (2250-2569 m), kar je solidna podlaga za razmejitev med evrosibirsko-severnoameriško in alpsko-nordijsko regijo ter alpsko provinco. V obravnavanem območju HAYEK (ibid.) piše še o prisotnosti panonske flore, ki pa je danes ne bi tako uvrščali, morda le nekatere vrste, širše razumljene kot panonske vrste, Dianthus barbatus, Helleborus odorus, Silene viridiflora, Galium aristatum, Centaurea variegata, C. fritschii, Ophrys holosericea, Tunica saxifraga, Linum tenuifolium, L. flavum.

V svoji študiji za Štajersko HaYek (1923) slovenski del Štajerske omejuje od Šentilja na severu do Brežic (Obrežja) na jugu ter od severnih pobočij zahodnih Kamniških planin (Ojstrica) in južnih zahodnih Karavank (Olševa) do Haloz na vzhodu. To območje deli na dve fitogeografski območji: evropsko-sibirsko gozdno in alpsko območje. Prvo območje deli na okrožja in sicer na južnonemško, subalpinsko in avstrijsko okrožje, ta pa še na štiri podokrožja. Za naše razmišljanje o delitvi fitogeografskih provinc Slovenije so zanimiva severovzhodnoalpsko in ilirsko podokrožje subalpinskega okrožja ter panonsko podokrožje avstrijskega okrožja. Drugo, alpsko območje deli na okrožji Severnih apneniških in Centralnih Alp ter Južnih apenin- 
ških Alp s šestimi podokrožji. Od teh šestih podokrožij je za nas zanimivo julijskoalpsko podokrožje okrožja Južnih apneniških Alp ter deloma norijskoalpsko podokrožje okrožja Severnih apneniških in Centralnih Alp. Za opredelitev fitogeografskih območij, okrožij in podokrožij, zlasti ilirskih, so mu služile razširjenosti nekaterih toploljubnih sicer splošno razširjenih jugovzhodnoevropsko-ilirskih vrst: Ostrya carpinifolia in Fraxinus ornus (njuna severna meja je Dravograd-Velenje-Slov. Bistrica-Macelj-Ptuj) ter Castanea sativa (severna meja: do Gradca), pa tudi razširjenost vinske trte (severna meja: Radlje, meja z Avstrijo-RušeHoče-Slov. Bistrica in nato po njegovi meji razširjenosti vrst Ostrya carpinifolia in Fraxinus ornus - Dravograd). Njegova razmejitev med ilirsko in srednjeevropsko fitogeografsko provinco, kot ju razumemo danes, je presenetljivo točna, če upoštevamo tedanja manj raziskana ozemlja Kranjske in Koroške ter skromno literaturo. Opiral se je predvsem na BecKa (1907-13).

BECK (1907-13) je naše etnično ozemlje botanično in še posebej fitogeografsko raziskoval ob koncu 19. in v začetku 20. stoletja. Zamejil je mediteransko, ilirsko in srednjeevropsko floro ter vse to prikazal na karti. Današnjo zahodno Slovenijo je uvrstil v mediteransko regijo vse do Kanala, Volč in Breginja (Breginjskega kota). Njegova razmejitev je solidna podlaga za poznejše fitogeografe. Bil je natančen, včasih celo zelo natančen: kot primer navajamo opisana nahajlišča ilirske (jugovzhodnoevropsko-ilirske) flore v dolini Završnice pod Karavankami, in sicer: Aremonia agrimonioides, Cardamine enneaphyllos, C. trifolia, C. waldsteinii, Hacquetia epipactis, Lamium orvala, Omphalodes verna, Vicia oroboides idr.

Po drugi svetovni vojni do danes se je pri nas zvrstilo kar nekaj botanikov in fitocenologov, ki so raziskovali fitogeografsko razdelitev Slovenije in na različne načine reševali tovrstne probleme. Med prvimi fitogeografi je bil botanik MAYER (1946). V svoji disertaciji je floristično analiziral Jugovzhodne apneniške Alpe in prišel do sklepa o uvrstitvi Vzhodnih apneniških Alp v alpsko provinco. To uvrstitev potrjuje s pojavljanjem alpinsko-severnoevropske (npr. Nigritella "nigra" (=rhelicani), Campanula barbata, Euphrasia minima), alpinsko-srednjeevropske (npr. Saxifraga caesia, Primula auricula, Soldanella alpina, Homogyne alpina), alpinske (npr. Rumex nivalis, Androsace helvetica, Valeriana supina), alpsko-arktično-altajske (npr. Salix herbacea, S. reticulata, Polygonum viviparum, Androsace chamaejasme), alpsko-arktične (npr. Silene acaulis, Bartsia alpina, Gentiana nivalis), alpsko-altajske flore (npr.: Coeloglossum viride, Salix retusa, Veronica aphylla, Leontopodim alpinum) in endemitov (npr.: Cerastium julicum, Campanula zoysii, Gentiana froelichii,
Saxifraga hohenwartii, Leucanthemun lithopolitanicum, Nigritella lithopolitanica). Pozneje je MAyer (1950, 1951, 1952, 1953, 1960) v prispevkih o flori še utrdil uvrstitev naših Vzhodnih apneniških Alp v alpsko provinco oziroma nakazal razširjenost ilirske province.

Botaničarka Nada Praprotnik (1987) je v svoji disertaciji o ilirskih flornih elementih podrobno razčlenila fitogeografsko pripadnost bolj ali manj ilirskih vrst v Sloveniji. Razvrstila jih je v 13 fitogeografskih enot (kategorij) in prikazala njihovo razširjenost (areale) v Sloveniji. Njena študija je dobro pomagalo k poznavanju razširjenosti ilirske in ilirsko jadranske florne province v Sloveniji. Za ponazoritev navajamo nekaj vrst, na katere smo se najbolj sklicevali kot na ilirske vrste:

Ilirski florni elementi: Helleborus atrorubens, Scabiosa hladnikiana, Scilla litardieri idr.

Submediteransko-ilirski elementi: Anthriscus fumaroides, Satureja subspicata, Sesleria autumnalis idr.

Severozahodno-ilirski elementi: Arabis scopoliana, Hladnikia pastinacifolia, Potentilla carniolica idr.

Subilirski elementi: Frangula rupestris, Gentiana tergestina, Potentilla tommasiniana idr.

Alpsko-ilirski elementi: Homogyne sylvestris, Lamium orvala, Vicia oroboides idr.

Apeninsko-ilirski elementi: Corydalis ochroleuca (=Pseudofumaria alba), Genista sylvestris, Sesleria juncifolia idr.

Karpatsko-ilirski elementi: Daphne blagayana, Euphrasia liburnica.

Taksoni s širšim arealom: Cardamine kitaibelli, Epimedium alpinum, Grafia golaka idr.

Taksoni z alpsko-karpatsko-ilirsko razširjenostjo: Euphorbia carniolica, Hacquetia epipactis, Hypericum alpinum idr.

Taksoni z južnoevropsko, jugovzhodnoevropsko in širšo razširjenostjo: Anemone trifolia, Aremonia agrimonioides, Cardamine trifolia, Geranium nodosum, Omphalodes verna idr.

Taksoni, ki so najbolj pogosti v submediteranski združbah: Fraxinus ornus, Ostrya carpinifolia, Pinus nigra idr.

Taksoni, ki so najbolj pogosti v združbah subalpinsekga in alpinskega pasu: Centaurea triumfettii, Scorzonera rosea, Thymus balcanus idr.

Taksoni z nejasnim taksonomskim položajem so danes večinoma uvrščeni $\mathrm{v}(1)$ arktično-alpske oz. med jugovzhodnoalpske in (2) med evromediteranske vrste, npr. vrsti Arabis alpina subsp. alpina (1) in Asperula aristata (2) idr. Dokazano je tudi, da pri nas ne uspeva podvrsta Helleborus niger subsp. macranthus. Na dolomitni ali dolomitizirani geološki podlagi $\mathrm{v}$ gorskem (montanskem) pasu raste Helleborus niger subsp. niger. 
Podobno analizo ilirskih in njim sorodnih vrst, kot so alpsko-ilirske, karpatsko-ilirske, panonsko-ilirske, italsko-ilirske, dacijsko-ilirske, submediteransko-ilirske, balkanske idr. vrste, je naredil BorHIDI (1963), ko je utemeljeval ilirsko zvezo bukovih gozdov Aremonio-Fagion (=Fagion illyricum). Na tej floristični osnovi je prikazal razširjenost ilirske zveze bukovih gozdov (BorHidi 1963: 260, 266), ki bi ustrezala arealu ilirske florne province. Kot lahko razberemo iz slike, ki je v zelo majhnem merilu, večino Slovenije pokriva zveza ilirskih bukovih gozdov, kar bi šteli za ilirsko florno provinco. Izvzeta sta primorski in predpanonski pas Slovenije. V tem merilu ni mogel izločiti alpskega pasu Slovenije.

Horvat (1954, 1962 a) je podal fitogeografsko delitev jugovzhodne Evrope, v kateri je zajeta tudi Slovenija. Fitogeografska analiza s predstavitvijo karte klimatogene vegetacije Jugovzhodne Evrope razčlenjuje klimatogeno vegetacijo po horizontalni razširjenosti in vertikalnih pasovih. Na osnovi te delitve je ugotovil, da so v jugovzhodni Evropi po Braun-Blanquetu zastopane tri vegetacijske regije: mediteranska, evrosibirsko-severnoameriška in iransko-turanska. Mediteransko-submediteransko florno območje uvršča v mediteransko, srednjeevropsko florno območje pa v evrosibirsko-severnoameriško regijo. $\mathrm{V}$ razpravi (HoRvat 1962 b) potrjuje svojo odločitev iz prej navedenih publikacij s tem, da v karto potencialne vegetacije izriše meje med mediteranskim in srednjeevropskim območjem štirih fitogeografov Adamovića, Markgrafa, Oberdorferja in Riklija, ki so zelo različne. Sam ostaja pri delitvi na osnovi potencialne vegetacije, kot jo predstavlja v svojih delih (Horvat 1954, 1962 a, b). Njegova karta klimatogene vegetacije zajema le manjši, jugovzhodni del Slovenije, ki ga uvršča v submediteransko območje (klimatogene) vegetacije Carpinetum orientalis croaticum in Seslerio-Ostryetum.

Horvatić $(1957,1963)$ ugotavlja, da sta mediteranska in submediteranska cona na območju osrednjega Balkanskega polotoka (nekdanja Jugoslavija) medsebojno bolje povezani kot submediteranska cona s kontinentalnim območjem evrosibirsko-severnoameriške regije. Mediteransko in submediteransko območje uvršča v mediteransko regijo. Primorje deli v tri cone:

1. v vzhodnojadransko eumediteransko cono (Quercion ilicis),

2. vzhodnojadransko submediteransko cono (Carpinetum orientalis croaticum),

3. vzhodnojadranski mediteransko-montanski pas (Seslerio autumnalis-Ostryetum).

Horvatić (1967) je pozneje delil jugoslovansko Primorje na dve provinci: jadransko in egejsko, obe pozneje v sklopu mediteranske regije. Evrosibirsko-se- vernoameriško regijo pa je delil na tri oziroma štiri province: ilirsko, mezijsko, ilirsko in mezijsko $\mathrm{v}$ pasu ruševja ter srednjeevropsko provinco - panonski sektor z nižinskim in gorskim pasom. Slovenijo uvršča v dve provinci, in sicer v jadransko - submediteransko (mediteransko regijo) in ilirsko provinco (evrosibirsko-severnoameriško regijo). Pas planinske vegetacije uvršča v alpsko-visokonordijsko regijo. Pas ruševja uvršča v ilirsko provinco.

Trinajstić $(1976,1986,1995)$ se je po obdobju starejših hrvaških fitogeografskih raziskav največ in najintenzivneje ukvarjal s fitogeografsko problematiko Hrvaške, zlasti njenega Primorja. Če poenostavimo njegovo fitogeografsko delitev Kvarnerskega zaliva, ki se proti zahodu navezuje na Slovensko primorje, TrINAJSTIĆ (1976) ožje submediteransko območje uvršča v mediteransko regijo. Paramediteransko cono, to je litoralni pas s toploljubnimi bukovimi gozdovi, pa uvršča $\mathrm{v}$ evrosibirsko-severnoameriško regijo skupaj $\mathrm{z}$ ilirsko, dinarsko, subilirsko-subalpinsko (zanimivo!), borealno-subalpinsko, ilirsko-balkansko, subalpinsko- ilirsko-balkansko vegetacijsko cono. Z njegovo fitogeografsko delitvijo bi se lahko načeloma strinjali za našo Istro. Pozneje je Trinajstić (1995) še podrobneje fitogeografsko razčlenil gozdno vegetacijo Hrvaške. Podrobneje obravnava fitogeografsko delitev evrosibirsko-severnoameriške regije. Njegova delitev te regije je zanimiva in sprejemljiva (Trinajstić 1995: 40-42). Mediteranske regije ne spreminja, kot je nakazal leta 1986 (Trinajstić 1986), in je fitogeografsko ustrezno urejena na cone $\mathrm{v}$ mediteransko-litoralni in mediteransko-montanski pas. Pojavlja se vprašanje, ali je pravilno, da uvršča submediteransko vegetacijsko cono mediteransko-litoralnega pasu $\mathrm{v}$ mediteransko regijo.

Šugar je temeljito raziskoval območje hrvaške Istre, ki je neposredna soseda slovenske. Njegova teza je, da submediteransko območje ( $v$ najširšem pomenu) Istre uvršča $\mathrm{v}$ srednjeevropsko-severnoameriško in ne $\mathrm{v}$ mediteransko regijo. Vprašanje je, kam uvrščati cono, v kateri se vzdržema pojavlja črničevje - Quercus ilex (ŠUGAR, 1984). Istrski submediteran kot zaokroženo celoto (s. lat.) ŠUGar et al. (1995) delijo v submediteransko s. str. (Querco-Carpinetum orientalis), epimediteransko (Ostryo-Quercetum pubescentis), histrijsko (Molinio-Quercetum pubescentis, Potentillo albae-Querceetum pubescentis) in paramediteransko cono (Seslerio-Fagetum) evrosibirsko-severnoameriške regije, kamor je uvrščena nadstojna ilirska cona (Fagetum s. lat.). Malopovršinsko priobalno, eumediteransko cono (Orno-Querectum ilicis) pa uvrščajo v mediteransko regijo. Cona zimzelene vegetacije (Quercetum ilicis) je le na Brionskih otokih. Gorati del Istre zavzema 
ilirska cona (Seslerion tenuifoliae) oromediteranske (sredozemsko-planinske) regije.

Za določitev ilirske florne province $\mathrm{v}$ Sloveniji je pomembna fitogeografska delitev Slovenije M. WRABERJA (1969). To je prva kartografsko predstavljena fitogeografska delitev Slovenije na floristični in vegetacijski osnovi, vendar še pod precejšnim vplivom geografske delitve Slovenije. Na osnovi njegove delitve lahko sklepamo na pojavljanje različnih florističnih provinc v Sloveniji. M. Wraber (ibid.) ugotavlja, da je na severu in zahodu Slovenije razširjena srednjeevropska provinca, na jugovzhodu pa ilirska provinca z ilirsko-balkanskim rastlinstvom. Južni del Slovenije je sredozemski, mediteransko-montanski in submediteranski. Po njegovi fitogeografski karti in razmišljanju sodeč pripada alpsko območje v srednjeevropsko provinco, toda $\mathrm{v}$ nižinah $\mathrm{z}$ ilirsko-balkanskimi in ilirsko-južnoevropskimi elementi. Predalpsko in preddinarsko območje opredeljuje kot mešanico alpsko-srednjeevropskih in ilirsko-dinarskih geoelementov. Dinarsko območje označuje ilirsko-balkanska flora. Subpanonsko območje ima panonski vegetacijski karakter (brez izrazitih panonskih vrst, op. piscev), kjer se tu in tam pojavlja ilirska flora. V sosednji Madžarski panonsko območje uvrščajo (Soó 1961, Pocs 1960, KARPATI 1966) v prenorijsko provinco z distriktoma Castriferricum in Poetovicum, v katerega bi bilo vključeno naše subpanonsko območje. Submediteransko območje Wraber (1969) uvršča v jadransko provinco, ki se pri nas končuje oziroma, kot pravi, se „izklinja“ ali „izzveni“. (ibid.)

Ž. Košs̃ (1975) je razdelil Slovenijo na pet fitoklimatskih teritorijev: submediteranski, dinarski, alpski in predalpski, preddinarski ter subpanonski teritorij. Iz fitoklimatskih teritorijev ni mogoče razbrati meje med florističnimi provincami. Ugotavljamo pa, da so, razen preddinarskega fitoklimata, vsi drugi fitoklimati identični s fitogeografskimi območji M. Wraberja. Iz razširjenosti Koširjevega preddinarsekga fitoklimata lahko sklepamo, da po njegovem ilirska florna provinca sega globoko v severovzhodni in deloma vzhodni del Slovenije, ki sega v sosednjo južno Avstrijo, ki že spada v norijsko florno provinco. Koširjeva odločitev za tako razsežno ilirsko florno provinco izhaja iz Potencialne fitocenološke karte Biroja za gozdarsko načrtovanje $\mathrm{v}$ merilu 1 : 100.000, ki prikazuje precejšen delež bazičnega do zmerno zakisanega bukovega gozda Hedero-Fagetum (Querco-Fagetum) in subpanonskega zmerno bazičnega do nevtralnega (slabo kislega) bukovega gozda (Festuco drymeiae-Fagetum). Kakšen je površinski delež enega in drugega, je v novejših raziskavah obveljalo drugačno mišljenje. Novejše raziskave kažejo drugačno podobo gozdne vegetacije, dopolnje- ne $\mathrm{z}$ negozdnimi združbami in florističnimi preučevanji.

MARINČEK (1994) na podlagi vegetacije in nekaterih ilirskih vrst predlaga mejo ilirske florne province na osrednjem Balkanskem polotoku oziroma na ozemlju nekdanje Jugoslavije. Glede na ohlapno pojmovanje (definiranje) in na podlagi splošnih fitogeografskih kart v neznanem merilu lahko sklepamo, da je ilirska florna provinca razširjena od Slovenije do Makedonije brez obalnega pasu, na severovzhodu pa se zajeda $\mathrm{v}$ mezijsko florno provinco. Posamezni otoki ilirske florne province so razširjeni tudi v panonsko-mezijskem območju. Ilirsko florno provinco deli na štiri območja, in sicer na predalpsko-alpsko območje na zahodu, subpanonsko območje od severozahoda do severovzhoda, dinarsko območje od jugovzhoda do jugozahoda in preddinarsko območje $\mathrm{v}$ vmesnem raztrganem pasu med subpanonskim in dinarskim območjem. Marinček je precej generaliziral omenjena fitogeografska območja in $\mathrm{v}$ precejšnji meri posnemal Meusla s sodelavci (1965). Po Marinčku so v Sloveniji prisotna vsa štiri območja.

Meusel s sodelavci (1965) je v primerjalni horologiji za srednjeevropsko floro prikazal, da Slovenija leži v območju zahodnoilirske in prenorijsko-slovenske floristične province. Karta je zelo generalizirana. Zanimiva je definicija prenorijsko-slovenske floristične province, ki je bolj ali manj usklajena z madžarskimi botaniki oziroma fitocenologi (Soó 1961, Pocs 1960, KARPATI 1966).

Osnovno fitogeografsko delitev Slovenije M. Wraberja (1969) je dopolnil ZupančIČ s sodelavci (1987) (ZUPANČIČ \& ŽAGAR 1995). V obeh primerih gre za dopolnila na ravneh distriktov. Zdaj poznamo 32 distriktov, ki so utemeljeni na posebnostih flore in vegetacije. Distrikte uvrščamo v štiri province (oziroma pet provinc) in dve regiji:

alpsko-visokonordijska regija:

alpska provinca s štirimi distrikti;

evrosibirsko-severnoameriška regija:

srednjeevropska provinca s petimi distrikti,

ilirska provinca $\mathrm{z}$ osemnajstimi distrikti in

ilirsko jadranska provinca s štirimi distrikti

ter prenorijsko-slovenska provinca $\mathrm{z}$ enim distriktom.

Slovensko submediteransko območje so M. WRABer (1969), Horvat (1954, 1962 a, b), Horvatić (1957, 1963, 1967), Trinajstić $(1976,1986,1995)$, Zupančič et al. (1982), Zupančič \& ŽaGAR (1995) uvrščali v mediteransko regijo. ŠUGAR (1984) je glede na mešane listopadne in zimzelene gozdove in grmišča hrvaško in slovensko submediteransko območje uvrstil v evrosibirsko-severnoameriško regijo. To njegovo 
misel so z določenimi pomisleki in zadržki sprejeli soavtorji razprave o gozdu puhastega hrasta in stožke rastočih na območju hrvaške in slovenske Istre (ŠUGAR et al. 1995). Nadaljnje raziskave vegetacije so pokazale, da slovensko submediteransko območje, ki sega najvišje proti severozahodu Slovenije, proti zahodnim Julijskim Alpam, uvrstimo v evrosibirsko-severnoameriško regijo (ZupanČič 1997). V sloven- skem submediteranskem območju je $\mathrm{v}$ gozdno-grmiščnih združbah večina listopadnega in majhen delež zimzelenega drevja ali grmičevja. Naš submediteran ima hladnejše podnebje in je bolj namočen kot na jugovzhodnem območju Balkanskega polotoka. OGRIN (1995) pravi, da je naše submediteransko območje zmerno toplo $\mathrm{z}$ vlažnim podnebjem, kjer so topla le poletja.

\section{SKLEP}

Območje ilirske florne province v Sloveniji želimo definirati in zamejiti na podlagi pogostnosti pojavljanja jugovzhodnoevropsko-ilirskih (ilirskih, ilirikoidnih, subilirskih) vrst $v$ posameznih fitogeografskih enotah - distriktih v celoti ali njihovih delih ter na podlagi rezultatov fitogegorafskih raziskovanj preučevalcev, navedenih v poglavju, ki govori o problemih delitve na florne province. Upoštevali smo bolj ali manj vse navedene raziskovalce, najbolj pa smo se naslanjali na Becka $(1907,1908,1913)$, Hayeka $(1907,1923)$, Horvata $(1954,1962$ A, B), Horvatića $(1957,1963,1967)$, Koširja (1975), Mayerja (1946, 1950, 1951，1952, 1953, 1960), Šugarja (1984), Šugarja et al. (1995), Trinajstića (1976, 1986, 1995), Wraberja (1969), ZupančIČA et al. (1987) in ZupančIČA \& ŽAGARJA (1995).

Kot osnovo za grafični prikaz ilirske florne province smo vzeli fitogeografsko karto WRABERJA (1969) in ZUPANČIČA s sodelavci (1987, ZuPANČIČA \& ŽAGARJA 1995).

Glede na Wraberjevo (1969) fitogeografsko karto je ilirska provinca omejena na severovzhodu s srednjeevropsko florno provinco v skrajnem območju subpanonskega fitogeografskega območja in na ozkem severnem obrobju alpskega fitogeografskega območja. Iz ilirske florne province je izvzeto submediteransko fitogeografsko območje, ki ga uvrščamo v sorodno ilirsko-jadransko provinco z mnogimi toploljubnimi geoelementi.

Podrobnejša fitogeografska karta ZupANČıča s sodelavci (1987) (ZupANČıč \& ŽAGAR 1995) je razdeljena po distriktih. Na osnovi distriktov ugotavljamo, da je ilirska florna provinca razširjena $\mathrm{v}$ večini distriktov, razen $\mathrm{v}$ distriktih 1a-1d, ki pripadajo alpski florni provinci, 2a-2c, 3a in severni del distrikta 4c, ki jih uvrščamo v srednjeevropsko florno provinco, in distrikte 7a-7d, ki spadajo v ilirsko-jadransko florno provinco.

Pri oblikovanju ilirske florne province imamo nekaj zadreg. Prvič, delitev distrikta 4c. Severni del distrikta zajema silikatna območja Pohorja, Strojne in
Dravskega Kozjaka (Kobansko), ki jih uvrščamo k srednjeevropski florni provinci. Verjetno bi morali ti območji izločiti iz distrikta $4 \mathrm{c}$ in utemeljiti nov distrikt (4d). Drugič, morda bi morali distrikt 3a uvrstiti v prenorijsko provinco v distrikt Poetovicum (Karpati 1966, Pocs 1960, Soó 1961) ali prenorijsko-slovensko (Meusel et al. 1965) provinco. Tretjič, ali je upravičena samostojna ilirskojadranska floristična provinca, ali pa bi jo morali priključiti k ilirski provinci, ki je razširjena v kontinentalnem območju Slovenije?

Najlažji je odgovor na tretje vprašanje. Ilirsko-jadransko floristično provinco določajo ilirsko-mediteranske vrste (npr. Carpinus orientalis, Eryngium amethystinum, Paliurus spina-christi, Sesleria autumnalis, Scorzonera villosa idr.), ilirsko-jadranske vrste (npr. Dianthus tergestinus, Drypis spinosa, Genista sylvestris idr.) in ilirsko-apeninske vrste (npr. Ruta graveolens idr.), med njimi so endemične vrste ter mnoge submediteranske in mediteranske vrste, kot so mediteransko-pontske (npr. Ruscus aculeatus, Chrysopogon gryllus idr.) ali mediteransko-atlantske (npr. Euphorbia peplis, Oenanthe pimpinelloides, Avena barbarta idr.) in še mnoge druge vrste.

Distrikt 4c bi kazalo razdeliti $\mathrm{v}$ dva dela: $\mathrm{v}$ sedanji štajersko-koroški $4 \mathrm{c}$ in novi pohorsko-kobanski distrikt $4 \mathrm{~d}$. Preučiti je treba, v čem se distrikta razlikujeta, kakšna je floristična in vegetacijska, klimatološka in pedološka razlika med njima. Vsekakor pa se razlikujeta v geološki podlagi in tudi bolj ali manj glede tal. Bežni pregled rastlinskih vrst kaže, da 16 vrst uspeva izključno le v pohorsko-kobanskem distriktu (4d). Od teh naj navedemo le najbolj redke ali zanimive, in sicer: Asplenium adulterinum, A. cuneifolium, Botrychium multifidum, Saxifraga paradoxa in Heliosperma veselskyi subsp. widderi.

V fitogeografski razdelitvi ZUPANČIČA in sodelavcev (1982) (ZUPANČIČ \& ŽAGAR 1995) je dravsko-murski distrikt 3a kot izjema uvrščen v transalpinski sektor in v poseben predpanonski podsektor, pri čemer oba spadata v srednjeevropsko provinco. Sektorsko 
ime pove, da je območje čezalpsko oziroma onkraj Alp (Leksikon CZ 1988). Vzhodno obrobje Centralnih Alp (Krške Alpe, Svinška planina, Golica, Pohorje) klimatsko vpliva na ravninsko-gričevnati svet Slovenskih goric, ki so v območju pri nas najbolj izrazite kontintalne klime. Zato predlagamo naslednjo sistemsko rešitev, da ptujski (dravsko-murski) distrikt 3a uvrstimo $\mathrm{v}$ prenorijsko-slovensko provinco po MeusLu in sodelavcih (1965) s transalpinskim sektorjem in predpanonskim podsektorjem. Tako bomo imeli v Sloveniji pet provinc, torej štiri province $\mathrm{v}$ evrosibirsko-severnoameriški regiji.

Območje florističnih provinc je razvidno iz fitogeografske karte Slovenije v merilu 1:920.000 (Karta 1).

\section{ACKNOWLEDGEMENTS}

The authors owe special thanks to Dr. Igor Dakskobler for his valuable comments and improvement of the manuscript. We also acknowledge the financial sup- port from the Slovenian Research Agency (research core funding No. P1-0236). Iztok Sajko prepared the Map 1. English translation by Martin Cregeen.

\section{LITERATURA - LITERATURE}

Accetto, M., 2010: Rastlinstvo Iškega vintgarja. Praprotnice in semenke. Folia biologica et geologica (Ljubljana) 51(4): 5-149.

Adamović, L., 1906: Die Pflanzengeographische Stellung und Gliederung der Balkanhalbinsel. Wien.

Beck-Mannagetta, G., 1907: Vegetationsstudien in den Ostalpen, I.-S. B. Akad. Wiss. 116: 1-96. Wien.

Beck-Mannagetta, G., 1908: Vegetationsstudien in den Ostalpen, II. - S. B. akad. Wiss. 122: 157-367. Wien.

Beck-Mannagetta, G., 1913: Vegetationsstudien in den Ostalpen, III. - S. B. akad. Wiss. 122: 157-367. Wien.

Borhidi, A., 1963: Die Zönolgie des Verbandes Fagion illyricum. Acta Botanica Academiae scientiarum Hungaricae (Budapest) 9: 259-297.

DAкsкoblen, I. \& B. Čušin, 2003: Rastlinstvo in rastje Dolenje Trebuše in njene okolice. Trebuški zbornik, Tolminski muzej (Tolmin): 99-132.

DAKsKobler, I., A. SelišKar \& B. VReš 2011: Rastlinstvo ob reki Idrijci-floristično-fitogeografska analiza obrečnega prostora $v$ sredogorju zahodne Slovenije. / Flora along the Idrijca river - floristic and phytogeographical analysis of the riparian area in the highlands of western Slovenia. Folia biologica et geologica (Ljubljana) 52(1-2): $27-86$.

DAKsкobler, I., 2015: Nekatere posebnosti flore in vegetacije severozahodnega dela Banjšic (zahodna Slovenija). / Some curiosities of the flora and vegetation of the northwestern Banjšice mountains (Western Slovenia). Folia biologica et geologica (Ljubljana) 56 (3): 25-36.

HАYек, A., 1907. Vorairbeiten zu einer pflanzengeographischen karte Oesterreichs. IV. Die Sanntaler Alpen. Abhandlungen der K. K. Zool. - Botan. Gesellschaft in Wien (Jena) IV (2): 1-73 + karte.

Hayek, A., 1923: Pflanzengeographie von Steiermark. Mitteilungen der Naturwiss. Ver. f. Steiermark. B Wiss. Abhands (Graz) 59: 1-208.

Honvat, I., 1954: Pflanzengeographische Gliederung Südosteuropas. (Den Haag). 5-6: 434-447.

Honvat, I. 1962 a : Die Grenze der mediterranen und mittelerupäischen Vegetation in Südosteruropa in Lichte neuer pflanzensocziologische Forscuhngen. Sonderdruck a. d. Berich. d. Deutsch. Bot. Gesell, (Halle/Saale) 75 (3): 91-104.

Horvat, I. 1962 b: Die Vegetation Südosteuropas in klimatschen und bodenkundlichen Zusammenhang. Mittel. d. Österreich. Geograph. Gesel. (Wien) 104 (1-2): 136-161.

Horvatić, S., 1957: Pflanzengeographische Gliederung des Karstes Kroatiens und der angrenzenden Gebiete Jugoswiens. Acta botanica Croatica (Zagreb) 16: 33-61.

Honvatić, S., 1963: Biljnogeografski položaj i raščlanjenje našeg Primorja u svjetlu suvremenih fitocenoloških istraživanja. Acta botanica Croatica (Zagreb) 22: 27-81.

Honvatić, S., 1967: Fitogeografske značajke i raščlanjanje Jugoslavije. Institut za botaniku sveučilišta u Zagrebu (Zagreb) Posebni otisak iz Analitičke flore Jugoslavije I/1: 23-61. 
Jogan, N., T. Bačič, B. Frajman, I. Leskovar, D. Naglič, A. Podobnik, B. Rozman, S. Strgulc-KrajšeK \& B. TRČAK, 2001: Gradivo za Atlas flore Slovenije = Materials for the Atlas of flora of Slovenia. Center za kartografijo favne in flore. Miklavž na Dravskem polju.

Karpati, Z., 1966: Einige pflanzengeographische und taxonomische Probleme in ungarischen ostalpenvorland Angewandte Pflanzensoz. (Wien): 18-19.

KošIR, Ž. 1975: Rastlinstvo. (v V. GREGORIČ, J. KALAN \& Ž. KOŠIR: Geološka in gozdnovegetacijska podoba). Gozdovi na Slovenskem (Ljubljana): 30-62.

MARINČEK, L., 1994: Contribution to demarcation and phytogeographic division of the illyrian floral province, based on vegetation and flora. Gortania (Udine) 16: 99-124.

Martinčič, A., T. Wraber, N. Jogan, A. Podobnik, B. Turk \& B. Vreš, 2007: Mala flora Slovenije. Ljubljana.

Mayer, E. 1946: Die floristische Gliederung der Hochgebirgsstufe in den südöstichen Kalkalpen und ihre Stellung innerhalb der Ostalpen. Disertacija. Universität Wien.

Mayer, E. 1950: Prispevek k flori slovenskega ozemlja. I. Univerza v Ljubljani.

MAYER, E. 1951: Kritični prispevki k flori slovenskega ozemlja. Razprave IV. razreda SAZU (Ljubljana) 1: 25-80.

Mayer, E. 1952: Prispevek k flori slovenskega ozemlja. III. Biol. vestnik (Ljubljana) 1: 66-79.

Mayer, E. 1953: Prispevek k flori slovenskega ozemlja. IV. Biol. vestnik (Ljubljana) 1: 66-72.

MAYER, E. 1960: Endemične cvetnice območja Jugovzhodnih apneniških Alp, njihovega predgorja in ilirskega prehodnega ozemlja. Ad annum Horti botanici Labacensis solemnem (Ljubljana): 25-48.

Meusel, H., E. Jäger \& E. Weinert, 1965: Vergleichende Chorologie der zentraluropäischen Flora. Jena.

Pocs, T., 1960: Die zonalen Waldgesellschaften Südwestungarns. Acta bot. Acad. Sci. Hung. (Budapest) 6.

Praprotnik, N. , 1987: Ilirski florni elementi v Sloveniji. Disertacija. Univ. E. Kardelja v Ljubljani, Ljubljana.

SelišKar, T., B. VReš \& A. SelišKar, 2003: FloVegSi 2.0 Računalniški program za urejanje in analizo bioloških podatkov. Biološki inštitut ZRC SAZU. Ljubljana.

Soó, R., 1961: Grundzüge zu einer neuen floristisch-zönologischen Pflanzengeographie Ungarns. Acta bot. Acad. Sci. Hung. (Budapest) 7.

KALIGARIČ, M., \& S. ŠKorNiK, 2002: Variety of dry and semi-dry secondary grasslands (Festuco-Brometea) in Slovenia - contact area of different geoelements. / Raznolikost suhih in polsuhih sekundarnih travišč (Festuco-Brometea) v Sloveniji - stičnem območju različnih geoelementov. Razprave 4. razr. SAZU (Ljubljana) 43 (3): 227-246.

ŠKonnik, S., 2003: Suha travišča reda Brometalia erecti Koch 1926 na Goričkem (SV Slovenija). Hacquetia (Ljubljana) 2 (1): 71-90.

ŠUGAR, I., 1984: Sul limite settentrionale della distribuzione zonale del leccio nel litorale Croato. Not.Fitosoc. 19 (1): $67-76$.

Šugar, I., M. Zupančič, I. Trinajstić \& I. Puncer, 1995: Forêts thermophiles de chêne pubescent et de molinie (Molinio-Quercetum pubescentis Šugar 1981) dans la zone limitrophe de Croatie et de Slovenie. Biološki vestnik (Ljubljana) 40 (3-4): 112-124.

Trinajstić, I., 1976: Pflanzengeographische Gliedernug der Vegetation des Quarnerischen Küstenlandes Kroatiens, Jugoslawien. Lokal wind bora. University of Tokyo (Tokyo): 257-265.

Trinajstić, I., 1986: Fitogeografsko razčlanjenje šumske vegetacije istočnojadrnskog sredozemnog područja - polazna osnovica u organizaciji gospodarenja mediteranskim šumama. Glas. šum. pokuse. (Zagreb) posebno izd. 2: $53-67$.

Trinajstić, I., 1995: Plantgeographical division of forest vegetation of Croatia. Annales forestales. Anali za za šumarstvo (Zagreb) 20 (2): 37-66.

Wraber, M., 1969: Pflanzengeographische Stellung und Gliedernung Sloweniens, Vegetatio (The Hague) 17 (1-6): 176-199.

Zupančič, M., L. MarinČek, A. SelišKar \& I. Puncer, 1987: Considerations on the phytogeographic division of Slovenia. Biogeographia 13. Biogeografia Alpi Sud-Orientali (Udine): 89-98.

ZupanČIČ, M. \& V. ŽAGAR, 1995: New wiews about the phytogeographic division of Slovenia, I. Razprave IV. razreda SAZU (Ljubljana) 36: 3-30. 
Table 3: List of plant species that thrive exclusively or predominantly in districts of the Alpine phytogeographic area. Tabela 3: Seznam rastlinskih vrst, ki izključno ali večinoma uspevajo v distriktih alpskega fitogeografskega območja

Androsace helvetica

Artemisia atrata

Cerastium uniflorum

Festuca alpestris

Festuca vivipara

Geum reptans

Helictotrichon versicolor

Hieracium alpinum

Papaver alpinum subsp. victoris

Rumex nivalis

Saxifraga exarata subsp. atropurpurea

Helictotrichon petzense

Nigritella kossutensis

Nigritella ravnikii

Primula minima

Senecio carniolicus

Viola zoysii

Androsace hausmannii

Cerastium julicum

Carex pauciflora

Trichophorum cespitosum

Artemisia genipi

Botrychium simplex

Festuca alpestris

Geranium argenteum

Helictotrichon pubescens subsp. laevigatum

Hieracium glabratum

Horminum pyrenaicum

Leontodon montanus

Luzula nivea

Minuartia rupestris

Pritzelago alpina subsp. austroalpina

Pulsatilla alpina subsp. apiifolia

Scorzoneroides crocea

Trifolium thalii

Trisetum spicatum

Nigritella archiducis-joannis

Nigritella widderi

Senecio fontanicola

Swertia perennis

Campanula alpina

Cardamine resedifolia

Jovibarba arenaria

Nigritella austriaca

Poa cenisia

Primula villosa

Taraxacum cucullatum

Woodsia alpina

Spiraea decumbens

Aconitum tauricum

Cardamine glauca

Silene rupestris

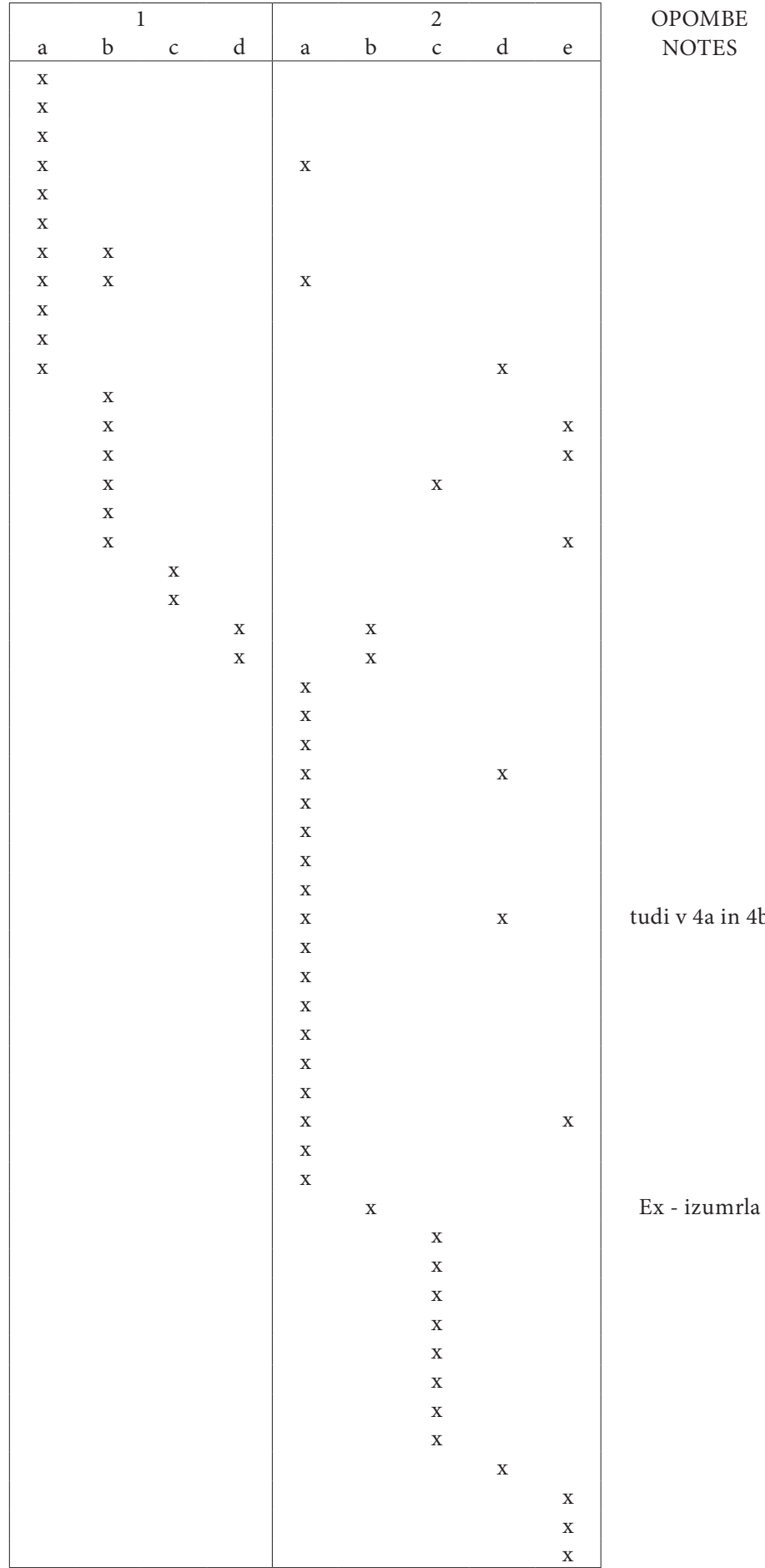


Table 4: Biological forms of species of districts of the Alpine phytogeographic area.

Tabela 4: Biološke oblike vrst distriktov alpskega fitogeografskega območja.

Hamefit

Geofit

Hemikriptofit

Terofit

\begin{tabular}{|c|c|c|c|c|c|c|c|c|}
\hline \multicolumn{4}{|c|}{1} & \multicolumn{5}{|c|}{2} \\
\hline a & b & c & d & $\mathrm{a}$ & $b$ & $c$ & d & $\mathrm{e}$ \\
\hline 1 & 1 & 1 & & 4 & & & & \\
\hline 1 & & & & 1 & 1 & & & 2 \\
\hline 2 & 1 & & & $\begin{array}{c}14 \\
1\end{array}$ & 1 & 6 & & 1 \\
\hline
\end{tabular}

Table 5: Geoelements of districts of the Alpine phytogeographic area.

Tabela 5: Geoelementi distriktov alpskega fitogeografskega območja.

Endemit / Endem.

Vzh. Alp. - Karp. / E Alp.-Carp.

Jugovzh. med. - mont. / SE Medit.-Mont.

Vzh. Alp. - Ilir. Endemit / E Alp.-Ilyr. Endem.

Alpski endemit / Alp. Endem.

Orof. Južnoevropski / Orof. S Eur.

Cirkum-arktično alpski / Circum.-Arct.-Alp.

Orof. Jugovzh. evrop. / Orof. SE Eur.

Orof. Jugozahod. evrop. / Orof. SW Eur.

Cent. Evrop. - Vzh. Alp. / Cent. Eur. - E Alp.

Centralno evropski / Centr. Eur.

Arktično-alpsko Evropski / Arct.-Alp.-Eur.

Subkosmopolitski / Subcosmopol.

Cirkumborealni / Circumboreal.

Jugovzhodevrop. - montan. / SE Eur.-Mont.

Vzhodnoalpski / E Alp.

Centralnoevrop. (atlantski) / Centr. Eur. (Atlant.)

Arktično-alpski Evroameriški / Art.-Alp. Eur.-Am.

\begin{tabular}{|c|c|c|c|c|c|c|c|c|}
\hline \multicolumn{4}{|c|}{1} & \multicolumn{5}{|c|}{2} \\
\hline $\mathrm{a}$ & b & $c$ & $\mathrm{~d}$ & $\mathrm{a}$ & $\mathrm{b}$ & c & d & $\mathrm{e}$ \\
\hline 2 & & 1 & & 4 & & 1 & & \\
\hline 1 & & & & & & & & \\
\hline 1 & & & & 1 & & & & \\
\hline & 1 & & & & & & & \\
\hline & 1 & & & 2 & & 2 & & \\
\hline & & & & 2 & & & & \\
\hline & & & & 2 & & & & \\
\hline & & & & 4 & & & & \\
\hline & & & & 1 & & & & \\
\hline & & & & 1 & & & & \\
\hline & & & & 1 & & & & 1 \\
\hline & & & & 1 & & & & \\
\hline & & & & 1 & & & & \\
\hline & & & & & 2 & 1 & & \\
\hline & & & & & & & & 1 \\
\hline & & & & & & 1 & & \\
\hline & & & & & & 1 & & \\
\hline & & & & & & & & 1 \\
\hline
\end{tabular}


Table 6: List of plant species that thrive exclusively in districts of the pre-Alpine phytogeographic area.

Tabela 6: Seznam rastlinskih vrst, ki izključno uspevajo v distriktih predalpskega fitogeografskega območja.

Amaranthus blitoides

Asperula taurina

Astragalus depressus

Eragrostis frankii

Euphorbia kerneri

Geranium macrorrhizum

Gladiolus imbricatus

Hieracium thesioides

Leontodon berinii

Leontodon hispidus subsp. brumatii

Melilotus italicus

Paradisea liliastrum

Pimpinella alpina

Pimpinella major subsp. rubra

Ranunculus aesontinus

Ranunculus cassubicus

Thesium rostratum

Moehringia villosa

Adonis aestivalis subsp. aestivalis

Allium suaveolens

Artemisia annua

Asperula tinctoria

Barbarea vulgaris var. arcuata

Bromus lepidus

Calla palustris

Carex randalpina

Carex pallidula

Crepis alpestris

Dianthus superbus

Diphasiastrum issleri

Diphasiastrum tristachyum

Doronicum orientale

Erigeron alpinus

Festuca brevipila

Fritillaria meleagris

Geranium thunbergii

Glyceria declinata

Hammarbya paludosa

Hypericum elodes

Hypericum maculatum subsp. obtusiusculum Lepidium perfoliatum

Melampyrum nemorosum subsp. moravicum

Miscanthus sinensis

Orchis palustris

Orlaya daucoides

Orobanche alsatica

Poa carniolica

Poa chaixii

Polygala vulgaris subsp. oxyptera

Rhinanthus alectorolophus subsp. buccalis

Sagittaria latifolia

Silaum silaus

Spiraea tomentosa

Thladiantha dubia

Trifolium squamosum

Urtica galeopsifolia

Utricularia bremii

Valeriana pratensis

Veronica peregrina subsp. xalapensis

Veronica serpyllifolia subsp. humifusa

Vicia serratifolia

Viola uliginosa

\begin{tabular}{|c|c|c|c|}
\hline \multicolumn{4}{|c|}{4} \\
\hline $\mathrm{a}$ & $\mathrm{b}$ & c & d \\
\hline $\mathrm{x}$ & & & \\
\hline $\mathrm{x}$ & & & \\
\hline $\mathrm{x}$ & & & \\
\hline $\mathrm{x}$ & & & \\
\hline $\mathrm{x}$ & & & \\
\hline $\mathrm{x}$ & & & \\
\hline $\mathrm{x}$ & & & \\
\hline $\mathrm{x}$ & & & \\
\hline $\mathrm{x}$ & & & \\
\hline $\mathrm{x}$ & & & \\
\hline $\mathrm{x}$ & & & \\
\hline $\mathrm{x}$ & & & \\
\hline $\mathrm{x}$ & & & \\
\hline $\mathrm{x}$ & & & \\
\hline $\mathrm{x}$ & & & \\
\hline $\mathrm{x}$ & $\mathrm{x}$ & & \\
\hline $\mathrm{x}$ & & & \\
\hline $\mathrm{x}$ & $\mathrm{x}$ & & \\
\hline & $\mathrm{x}$ & & \\
\hline & $\mathrm{x}$ & & \\
\hline & $\mathrm{x}$ & & \\
\hline & $x$ & & \\
\hline & $\mathrm{x}$ & & \\
\hline & $\mathrm{x}$ & & \\
\hline & $\mathrm{x}$ & & \\
\hline & $x$ & & \\
\hline & $\mathrm{x}$ & & \\
\hline & $\mathrm{x}$ & & \\
\hline & $\mathrm{x}$ & & \\
\hline & $\mathrm{x}$ & & \\
\hline & $\mathrm{x}$ & & \\
\hline & $\mathrm{x}$ & & \\
\hline & $\mathrm{x}$ & & \\
\hline & $\mathrm{x}$ & & \\
\hline & $\mathrm{x}$ & & \\
\hline & $\mathrm{x}$ & & \\
\hline & $\mathrm{x}$ & & \\
\hline & $\mathrm{x}$ & & \\
\hline & $\mathrm{x}$ & & \\
\hline & $\mathrm{x}$ & & \\
\hline & $\mathrm{x}$ & & \\
\hline & $\mathrm{x}$ & & \\
\hline & $\mathrm{x}$ & & \\
\hline & $\mathrm{x}$ & & \\
\hline & $\mathrm{x}$ & & \\
\hline & $\mathrm{x}$ & & \\
\hline & $\mathrm{x}$ & & \\
\hline & $\mathrm{x}$ & & \\
\hline & $\mathrm{x}$ & & \\
\hline & $\mathrm{x}$ & & \\
\hline & $\mathrm{x}$ & & \\
\hline & $\mathrm{x}$ & & \\
\hline & $\mathrm{x}$ & & \\
\hline & $\mathrm{x}$ & & \\
\hline & $\mathrm{x}$ & & \\
\hline & $\mathrm{x}$ & & \\
\hline & $\mathrm{x}$ & & \\
\hline & $\mathrm{x}$ & & \\
\hline & $\mathrm{x}$ & & \\
\hline & $\mathrm{x}$ & & \\
\hline & $\mathrm{x}$ & & \\
\hline & $\mathrm{x}$ & & \\
\hline
\end{tabular}

OPOMBE

tudi v SM

tudi v $2 \mathrm{~d}$

tudi v $2 \mathrm{~d}, 5 \mathrm{a}$

tudi v $2 \mathrm{a}$

tudi $v 6 \mathrm{~g}$ in $7 \mathrm{a}$

tudi v $2 \mathrm{~d}$

tudi v $7 \mathrm{~b}$

tudi v DN

tudi v $2 \mathrm{~d}$

tudiv $3 a, 6 c$

v $3 a, 5 b$

$\mathrm{v} 6 \mathrm{~b}$ 
Waldsteinia trifolia Asperugo procumbens Asplenium septentrionale Aster laevis

Carex disticha

Carex pallens

Chimaphila umbellata

Cynoglossum germanicum

Festuca pallens

Gentiana acaulis

Gentianella aspera

Hesperis sylvestris

Iberis pinnata

Jovibarba hirta

Lamium hybridum

Lotus borbasii

Lupinus polyphyllus

Lycopsis arvensis

Mimulus guttatus

Mimulus moschatus

Myosotis discolor

Nasturtium microphyllum

Orchis provincialis

Peltaria alliacea

Physocarpus opulifolius

Pisum arvense

Plantago arenaria

Primula veris subsp. canescens

Pyrus nivalis

Ranunculus thora f. pseudoscutatus

Rhus radicans

Romulea bulbocodium

Rubus styriacus

Rubus thyrsiflorus

Sedum villosum

Senecio alpinus

Stipa capillata

Valeriana sambucifolia

Asplenium adulterinum

Asplenium cuneifolium

Botrychium multifidum

Carex diandra

Epilobium obscurum

Rubus solvensis

Rubus venosus

Saxifraga paradoxa

Scleranthus polycarpos

Senecio subalpinus

Heliosperma veselskyi subsp. widderi

Sparganium oocarpum

Stellaria pallida

Swertia perennis

Woodsia ilvensis

Botrychium matricariifolium

Carex ericetorum

Cortusa matthioli

Epilobium nutans

Hypericum barbatum

Luzula divulgata

Lysimachia thyrsiflora

Ranunculus aconitifolius

Rhinanthus pulcher

Rubus gremlii

Sorbus latifolia s. lat.

Vicia pisiformis

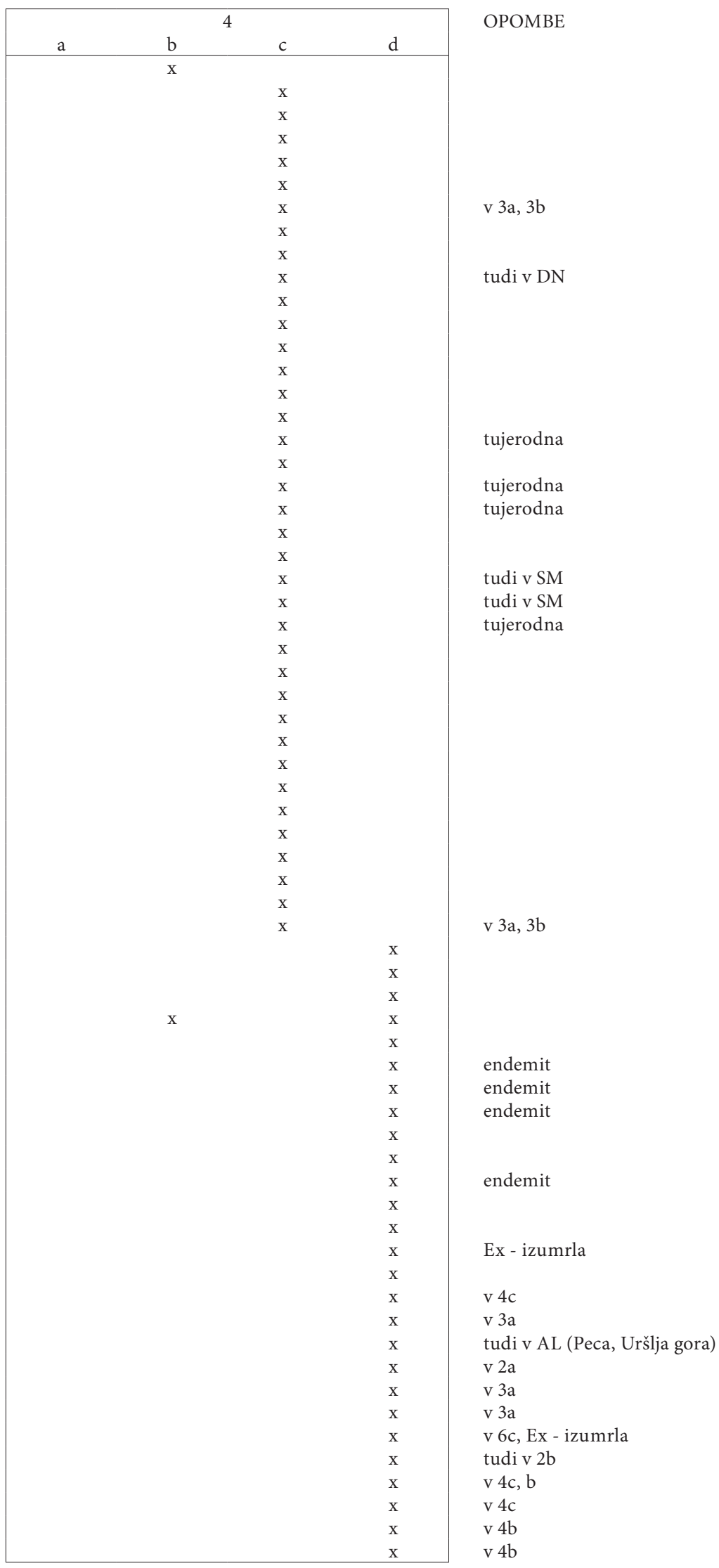


Table 7: Biological forms of species of districts of the pre-Alpine phytogeographic area. Tabela 7: Biološke oblike vrst distriktov predalpskega fitogeografskega območja.

Hemikriptofiti

Terofiti

Geofiti

Hamefiti

Fanerofiti

Helofit

Nanofanerofit

\begin{tabular}{|cccc|}
\hline $\mathrm{a}$ & $\mathrm{b}$ & 4 & $\mathrm{c}$ \\
\hline 11 & 16 & 20 & $\mathrm{~d}$ \\
3 & 10 & 9 & 3 \\
6 & 6 & 4 & 3 \\
2 & 5 & 2 & 3 \\
& 1 & 4 & 1 \\
\hline
\end{tabular}

Table 8: Geoelements of districts of the pre-Alpine phytogeographic area. Tabela 8: Geoelementi distriktov predalpskega fitogeografskega območja.

Adv. Naturalizirani / Adv. Natural.

Orof. Jugovzh. Evrop. / Orof. SE Eur.

Jugovzhod evropski. - juž. Sibir. / SE Eur.-S Sib.

Evropski / Eur.

Južno Ameriški / S Am.

Endemit / Endem.

Jugovzhod. Evrop. / SE Eur.

Orof. Jugozahod. Evrop. / Orof. SW Eur.

Stenomediter. Stenomedit.

Vzhod. Alpski E Alp.

Jugovzh. Evrop. - montan. / SE Eur.-Mont.

Evroazijski / Eurasiat.

Južno evrimediter. / S Eurimedit.

Kozmopolit. / Cosmopol.

Vzhodno Azijski / E Asiat.

Subatlantski / Subatl.

Evrosibir. - Severno Amer. / Eurosib.-N Am.

Zahodno Azijski / W Asiat.

Evropsko - Severno Amer. / Eur.-N Am.

Arktično Alpski / Arct.-Alp.

Orof. Evroazijski / Orof. Eurasiat.

Južno Evropski / S Eur.

Centralno Evropski / Centr. Eur.

Južno Evrop. - Južno Sibir. / S Eur.-S Sib.

Evromediter. / Eur.-Medit.

Evropsko - Kavkaški / Eur-Cauc.

Evrosibirski / Eurosib.

Orof. Južno Evropski / Orof. S Eur.

Paleotemperat. / Paleotemp.

Cirkumborealni / Circumbor.

Severno ameriški / N Am.

Jugovzhod. Evrop. - Jugozahod. Azijski / SE Eur.-SW Asiat. Severnomediter. / N Medit.

Eumediter. - Subatlantski / Eumedit.-Subatl.

Mediteranski / Medit.

Alpsko - Apeninski / Alp.-Apen.

Arktično - Alpski / Arct.-Alp.

Submediter. - Subatlant. / Submedit.-Subatl.

Vzhodnoalpsko - ilirski / E Alp.-Illyr.

Vzhodno Evrop. / E Eur.

\begin{tabular}{|c|c|c|c|}
\hline \multicolumn{4}{|c|}{4} \\
\hline $\mathrm{a}$ & $b$ & $c$ & d \\
\hline 1 & 2 & 3 & \\
\hline 3 & & 1 & \\
\hline 1 & & & \\
\hline 2 & 6 & 2 & 4 \\
\hline 1 & & & \\
\hline 6 & 1 & 2 & \\
\hline 1 & 3 & & 1 \\
\hline 1 & & & 1 \\
\hline 1 & & 2 & \\
\hline 1 & & & 1 \\
\hline 1 & & 1 & 1 \\
\hline 1 & 6 & 2 & \\
\hline & 1 & & \\
\hline & 1 & & \\
\hline & 2 & & \\
\hline & 2 & & \\
\hline & 1 & 1 & 1 \\
\hline & 1 & & \\
\hline & 2 & 1 & \\
\hline & 1 & & \\
\hline & 1 & & \\
\hline & 1 & & \\
\hline & 2 & 3 & 2 \\
\hline & 1 & & 1 \\
\hline & 3 & & \\
\hline & 1 & 1 & 1 \\
\hline & & 2 & 2 \\
\hline & 1 & 3 & 1 \\
\hline & & 1 & 1 \\
\hline & & 1 & 3 \\
\hline & & 5 & \\
\hline & & 1 & \\
\hline & & 1 & \\
\hline & & 1 & \\
\hline & & 1 & \\
\hline & & 1 & \\
\hline & & & 4 \\
\hline & & & 1 \\
\hline & & & 1 \\
\hline & & & 1 \\
\hline
\end{tabular}


Table 9: List of plant species that thrive exclusively or mostly in districts of the Dinaric phytogeographic area.

Tabela 9: Seznam rastlinskih vrst, ki izključno ali večinoma uspevajo v distriktih dinarskega fitogeografskega območja.

Cerastium decalvans

Euphorbia triflora s.str.

Festuca carniolica

Genista holopetala

Helianthemum rupifragum

Hladnikia pastinacifolia

Pedicularis comosa

Ranunculus wraberi

Thlaspi sylvestre

Scrophularia laciniata

Carex kitaibeliana

Festuca bosniaca

Hypericum richeri subsp. grisebachii

Myosotis suaveolens

Polygala croatica

Scabiosa silenifolia

Schoenus ferrugineus

Seseli malyi

Myosotis refracta

Sorbus carpatica

Thalictrum minus subsp. saxatile

Thymus balcanus

Trifolium velebiticum

Veronica triloba

Vicia articulata

Viola elatior

Cerastium dinaricum

Adenophora liliifolia

\begin{tabular}{|c|c|c|c|}
\hline \multicolumn{4}{|c|}{5} \\
\hline $\mathrm{a}$ & $\mathrm{b}$ & c & $\mathrm{d}$ \\
\hline $\mathrm{x}$ & & & \\
\hline $\mathrm{x}$ & & & \\
\hline $\mathrm{x}$ & & & \\
\hline $\mathrm{x}$ & & & \\
\hline $\mathrm{x}$ & & & \\
\hline $\mathrm{x}$ & & & \\
\hline $\mathrm{x}$ & & & \\
\hline $\mathrm{x}$ & & & \\
\hline $\mathrm{x}$ & & & \\
\hline $\mathrm{x}$ & $\mathrm{x}$ & & \\
\hline & $\mathrm{x}$ & & \\
\hline & $\mathrm{x}$ & & \\
\hline & $\mathrm{x}$ & & \\
\hline & $\mathrm{x}$ & & \\
\hline & $\mathrm{x}$ & & \\
\hline & $\mathrm{x}$ & & $x$ \\
\hline & $\mathrm{x}$ & & \\
\hline & $\mathrm{x}$ & & \\
\hline & $\mathrm{x}$ & & \\
\hline & $\mathrm{x}$ & & \\
\hline & $\mathrm{x}$ & & \\
\hline & $\mathrm{x}$ & & \\
\hline & $\mathrm{X}$ & & \\
\hline & $\mathrm{x}$ & & \\
\hline & $\mathrm{x}$ & & \\
\hline & $\mathrm{x}$ & & \\
\hline & $\mathrm{x}$ & & \\
\hline & & & $\mathrm{x}$ \\
\hline
\end{tabular}

OPOMBE

tudi v $2 \mathrm{~d}$

tudi v 2e (Kamniške Alpe)

tudi v 2a, 4b, $6 \mathrm{~d}$

tudi v $6 \mathrm{~g}$

Table 10: Biological forms of species of districts of the Dinaric phytogeographic area.

Tabela 10: Biološke oblike vrst distriktov dinarskega fitogeografskega območja.

Hemikriptofiti

Terofiti

Fanerofiti

Hamefiti

\begin{tabular}{|c|c|c|c|}
\hline \multicolumn{4}{|c|}{5} \\
\hline a & $b$ & $\mathrm{c}$ & $\mathrm{d}$ \\
\hline 7 & 13 & & 2 \\
\hline & 3 & & \\
\hline & 1 & & \\
\hline 3 & 1 & & \\
\hline
\end{tabular}


Table 11: Geoelements of districts of the Dinaric phytogeographic area.

Tabela 11: Geoelementi distriktov dinarskega fitogeografskega območja.

Ilirski / Illyr.

Evropsko-montanski / Eur.-Mont.

Juž. Evrop. - Mont. / S Eur.-Mont.

Jugovzhod. Evrop. - Mont. / SE Eur.-Mont.

Severovzh. mediter.-mont. / NE Medit.-Mont.

Mediteranski / Medit.

Evropski / Eur.

Evro-Azijski / Eur.-Asiat.

\begin{tabular}{|c|c|c|c|}
\hline \multicolumn{4}{|c|}{5} \\
\hline $\mathrm{a}$ & $b$ & $c$ & $\mathrm{~d}$ \\
\hline 7 & 9 & & \\
\hline 1 & & & \\
\hline 1 & 1 & & \\
\hline & 3 & & \\
\hline & 1 & & 1 \\
\hline & 2 & & \\
\hline & 1 & & \\
\hline & 1 & & 1 \\
\hline
\end{tabular}

Table 12: List of plant species that thrive exclusively in districts of the pre-Dinaric phytogeographic area.

Tabela 12: Seznam rastlinskih vrst, ki izključno uspevajo $v$ distriktih preddinarskega fitogeografskega območja.

Acer obtusatum

Aconitum variegatum subsp. nasutum

Aconitum vitosanum

Asplenium trichomanes subsp. pachyrachys

Euphorbia acuminata

Fumaria officinalis subsp. wirtgenii

Rosa blondaeana

Carex depauperata

Euphorbia lucida

Ranunculus mediocompositus

Scilla litardierei

Heliosperma veselskyi subsp. iskense

Ranunculus thora f. pseudoscutatus

Erysimum carniolicum

Dianthus giganteus subsp. croaticus

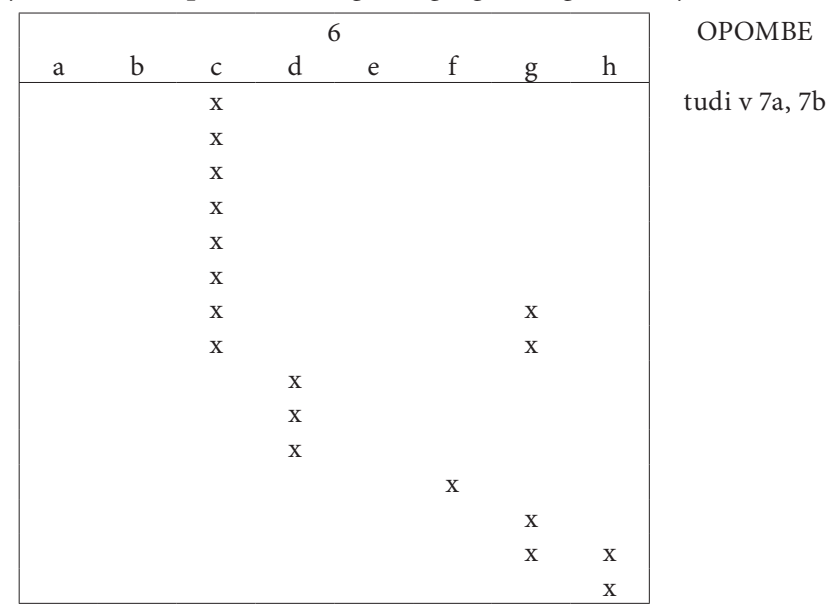

Table 13: Biological forms of species of districts of the pre-Dinaric phytogeographic area.

Tabela 13: Biološke oblike vrst distriktov preddinarskega fitogeografskega območja.

\begin{tabular}{|c|c|c|c|c|c|c|c|c|}
\hline \multirow[b]{3}{*}{ Hamefiti } & \multicolumn{8}{|c|}{6} \\
\hline & $\mathrm{a}$ & b & c & d & $\mathrm{e}$ & $\mathrm{f}$ & g & $\mathrm{h}$ \\
\hline & & & 1 & & & 1 & & \\
\hline Hemikriptofiti & & & 2 & 2 & & & 3 & 2 \\
\hline Fanerofiti & & & 2 & & & & 1 & \\
\hline Geofiti & & & 1 & 1 & & & & \\
\hline Terofiti & & & 2 & & & & & \\
\hline
\end{tabular}

Table 14: Geoelements of districts of the pre-Dinaric phytogeographic area.

Tabela 14: Geoelementi distriktov preddinarskega fitogeografskega območja.

Ilirski / Illyr.

Južno Evrop. / S Eur.

Mediter. - Zahod. Azijski / Medit.-W Asiat.

Evrop. - Azijski / Eur.-Asiat.

\begin{tabular}{|llllllll|}
\hline & & & & 6 & & & \\
a & $\mathrm{b}$ & $\mathrm{c}$ & $\mathrm{d}$ & $\mathrm{e}$ & $\mathrm{f}$ & $\mathrm{g}$ & $\mathrm{h}$ \\
\hline & & 2 & 2 & & 1 & 1 & 2 \\
& 4 & 1 & & & 2 & \\
& 1 & & & & & \\
& 1 & & & & 1 & \\
& & &
\end{tabular}


Table 15: List of plant species that thrive exclusively or mostly in districts of the sub-Mediterranean phytogeographic area. Tabela 15: Seznam rastlinskih vrst, ki izključno ali večinoma uspevajo v distriktih submediteranskega fitogeografskega območja.

Aristida longespica

Bidens vulgata

Cuscuta cesatiana

Fimbristylis annua

Galium rubioides

Helianthemum nitidum

Quercus virgiliana

Xeranthemum annuum

Aconitum anthora

Adonis microcarpa

Agrostis castellana var. mutica

Anthriscus fumarioides

Asplenium trichomanes subsp. quadrivalens

Bromus intermedius

Bunium bulbocastanum

Bupleurum exaltatum

Bupleurum ranunculoides subsp. ranunculoides

Calystegia sylvatica

Carduus collinus

Centaurea alpina

Corylus maxima

Sorbus mayeri

Festuca apennina

Festuca spectabilis

Festuca trichophylla

Fritillaria orientalis

Genista sericea

Genista sylvestris

Hieracium dragicola

Hieracium lasiophyllum

Hieracium scorzonerifolium

Hieracium wilczekianum

Iris pallida subsp. illyrica

Juncus atratus

Jurinea mollis

Lactuca virosa

Melampyrum velebiticum subsp. meridionale

Melica picta

Onobrychis tommasinii

Onosma visianii

Oplismenus undulatifolius

Ornithogalum nutans

Orobanche crenata

Orobanche nana

Paeonia mascula

Osyris alba

Poa sylvicola

Polycnemum majus

Prunus laurocerasus

Quercus crenata

Radiola linoides

Ranunculus illyricus

Ranunculus peltatus

Ranunculus pospichalii

Rhinanthus pampaninii

Sorbus mayeri

Smyrnium perfoliatum

Sorbus istriaca

Sorbus slavnicensis

Stachys lanata

Stipa eriocaulis subsp. carniolica

\begin{tabular}{|c|c|c|c|}
\hline \multicolumn{4}{|c|}{7} \\
\hline $\mathrm{a}$ & $\mathrm{b}$ & c & $\mathrm{d}$ \\
\hline $\mathrm{x}$ & & & \\
\hline $\mathrm{x}$ & & & \\
\hline $\mathrm{x}$ & & & \\
\hline $\mathrm{x}$ & & & \\
\hline $\mathrm{x}$ & & & \\
\hline $\mathrm{x}$ & & & \\
\hline $\mathrm{x}$ & & & \\
\hline $\mathrm{x}$ & & & \\
\hline & $\mathrm{x}$ & & \\
\hline & $\mathrm{x}$ & & \\
\hline & $\mathrm{x}$ & & \\
\hline & $\mathrm{x}$ & & \\
\hline & $\mathrm{x}$ & & \\
\hline & $\mathrm{x}$ & & \\
\hline & $\mathrm{x}$ & & \\
\hline & $\mathrm{x}$ & & \\
\hline & $\mathrm{x}$ & & \\
\hline & $\mathrm{x}$ & & \\
\hline & $\mathrm{x}$ & & \\
\hline & $\mathrm{x}$ & & \\
\hline & $\mathrm{x}$ & & \\
\hline & $\mathrm{x}$ & & \\
\hline & $\mathrm{x}$ & & \\
\hline & $\mathrm{x}$ & & \\
\hline & $\mathrm{x}$ & & \\
\hline & $\mathrm{x}$ & & \\
\hline & $\mathrm{x}$ & & \\
\hline & $\mathrm{x}$ & & \\
\hline & $\mathrm{x}$ & & \\
\hline & $\mathrm{x}$ & & \\
\hline & $\mathrm{x}$ & & \\
\hline & $\mathrm{x}$ & & \\
\hline & $\mathrm{x}$ & & \\
\hline & $\mathrm{x}$ & & \\
\hline & $\mathrm{x}$ & & \\
\hline & $\mathrm{x}$ & & \\
\hline & $\mathrm{x}$ & & \\
\hline & $\mathrm{x}$ & & \\
\hline & $\mathrm{x}$ & & \\
\hline & $\mathrm{x}$ & & \\
\hline & $\mathrm{x}$ & & \\
\hline & $\mathrm{x}$ & & \\
\hline & $\mathrm{x}$ & & \\
\hline & $\mathrm{x}$ & & \\
\hline & $\mathrm{x}$ & & \\
\hline & $\mathrm{x}$ & & \\
\hline & $\mathrm{x}$ & & \\
\hline & $\mathrm{x}$ & & \\
\hline & $\mathrm{x}$ & & \\
\hline & $\mathrm{x}$ & & \\
\hline & $\mathrm{x}$ & & \\
\hline & $\mathrm{x}$ & & \\
\hline & $\mathrm{x}$ & & \\
\hline & $\mathrm{x}$ & & \\
\hline & $\mathrm{x}$ & & \\
\hline & $\mathrm{x}$ & & \\
\hline & $\mathrm{x}$ & & \\
\hline & $\mathrm{X}$ & & \\
\hline & $\mathrm{x}$ & & \\
\hline & $\mathrm{x}$ & & \\
\hline & $\mathrm{x}$ & & \\
\hline
\end{tabular}

OPOMBE

Ex-izumrla

tudi v $5 \mathrm{a}$ in $5 \mathrm{~b}$

tudi $v 5 \mathrm{a}$ in $5 \mathrm{~b}$

v $4 \mathrm{a}$ 
Thymus carstiensis

Tordylium officinale

Trigonella gladiata

Atriplex sagittata

Echinops exaltatus

Festuca stricta

Lilium bulbiferum subsp. croceum

Viola kitaibeliana

Adiantum capillus-veneris

Adonis annua

Adonis flammea subsp. cortiana

Aegilops neglecta

Aegilops triuncialis

Allium neapolitanum

Anemone hortensis

Anisantha diandra subsp. rigida

Anthemis altissima

Anthemis segetalis

Anthyllis vulneraria subsp. praepropera

Arbutus unedo

Artemisia caerulescens

Arthrocnemum macrostachyum

Arundo plinii

Asparagus maritimus

Asplenium lepidum

Aster squamatus

Aster tripolium

Astragalus hamosus

Astragalus illyricus

Atriplex portulacoides

Atriplex tatarica

Avena barbata

Avena sterilis

Baldellia ranunculoides

Ballota rupestris

Bellevalia romana

Beta vulgaris subsp. maritima

Bifora radians

Bifora testiculata

Briza maxima

Bromus commutatus subsp. neglectus

Bromus hordeaceus subsp. molliformis

Bromus japonicus subsp. anatolicus

Bupleurum tenuissimum

Cakile maritima

Calendula arvensis

Carlina acanthifolia

Carpinus orientalis

Catapodium marinum

Catapodium rigidum subsp. majus

Centaurium spicatum

Centaurium tenuiflorum

Cephalaria leucantha

Cercis siliquastrum

Chenopodium hircinum

Coronilla cretica

Coronilla scorpioides

Crepis zacintha

Crithmum maritimum

Crupina vulgaris

Crypsis aculeata

Crypsis schoenoides

Cymodocea nodosa

Dasypyrum villosum

\begin{tabular}{|c|c|c|c|}
\hline \multicolumn{4}{|c|}{7} \\
\hline a & $b$ & $c$ & $\mathrm{~d}$ \\
\hline \multirow{64}{*}{$\mathrm{x}$} & $\mathrm{x}$ & & \\
\hline & $\mathrm{x}$ & & \\
\hline & $\mathrm{x}$ & & \\
\hline & & $\mathrm{x}$ & \\
\hline & & $\mathrm{x}$ & \\
\hline & & $\mathrm{x}$ & \\
\hline & & $\mathrm{x}$ & \\
\hline & & $\mathrm{x}$ & \\
\hline & & & $\mathrm{x}$ \\
\hline & & & $\mathrm{x}$ \\
\hline & & & $\mathrm{x}$ \\
\hline & & & $\mathrm{x}$ \\
\hline & & & $\mathrm{x}$ \\
\hline & & & $\mathrm{x}$ \\
\hline & & & $\mathrm{x}$ \\
\hline & & & $\mathrm{x}$ \\
\hline & & & $\mathrm{x}$ \\
\hline & & & $\mathrm{x}$ \\
\hline & & & $\mathrm{x}$ \\
\hline & & & $\mathrm{x}$ \\
\hline & & & $\mathrm{x}$ \\
\hline & & & $\mathrm{x}$ \\
\hline & & & $\mathrm{x}$ \\
\hline & & & $\mathrm{x}$ \\
\hline & & & $\mathrm{x}$ \\
\hline & & & $\mathrm{x}$ \\
\hline & & & $\mathrm{x}$ \\
\hline & & & $\mathrm{x}$ \\
\hline & & & $\mathrm{x}$ \\
\hline & & & $\mathrm{x}$ \\
\hline & & & $\mathrm{x}$ \\
\hline & & & $\mathrm{x}$ \\
\hline & & & $\mathrm{x}$ \\
\hline & & & $\mathrm{x}$ \\
\hline & & & $\mathrm{x}$ \\
\hline & & & $\mathrm{x}$ \\
\hline & & & $\mathrm{x}$ \\
\hline & & & $\mathrm{x}$ \\
\hline & & & $\mathrm{x}$ \\
\hline & & & $\mathrm{x}$ \\
\hline & & & $\mathrm{x}$ \\
\hline & & & $\mathrm{x}$ \\
\hline & & & $\mathrm{x}$ \\
\hline & & & $\mathrm{x}$ \\
\hline & & & $\mathrm{x}$ \\
\hline & & & $\mathrm{x}$ \\
\hline & & & $\mathrm{x}$ \\
\hline & $\mathrm{x}$ & & $\mathrm{x}$ \\
\hline & & & $\mathrm{x}$ \\
\hline & & & $\mathrm{x}$ \\
\hline & & & $\mathrm{x}$ \\
\hline & & & $\mathrm{x}$ \\
\hline & & & $\mathrm{x}$ \\
\hline & & & $\mathrm{x}$ \\
\hline & & & $\mathrm{x}$ \\
\hline & & & $\mathrm{x}$ \\
\hline & & & $\mathrm{x}$ \\
\hline & & & $\mathrm{x}$ \\
\hline & & & $\mathrm{x}$ \\
\hline & & & $\mathrm{x}$ \\
\hline & & & $\mathrm{x}$ \\
\hline & & & $\mathrm{x}$ \\
\hline & & & $\mathrm{x}$ \\
\hline & & & $\mathrm{x}$ \\
\hline
\end{tabular}

OPOMBE

tudi drugje

v $6 \mathrm{c}$

tudi v $4 \mathrm{a}$

tudi v $5 \mathrm{~d}$ in $6 \mathrm{c}$ 
Dittrichia viscosa

Dracunculus vulgaris

Ecballium elaterium

Echium italicum

Erodium malacoides

Eryngium maritimum

Fumaria capreolata

Hainardia cylindrica

Hedypnois cretica

Hippocrepis unisiliquosa

Hordeum marinum

Hyoscyamus albus

Inula crithmoides

Juncus acutus

Juncus littoralis

Juncus longicornis

Juncus maritimus

Kickxia elatine subsp. crinita

Lathyrus annuus

Lathyrus sativus

Lavandula angustifolia

Lavatera arborea

Legousia hybrida

Lens nigricans

Limonium angustifolium

Linaria angustissima

Linum liburnicum

Linum maritimum

Linum tommasinii

Linum trigynum

Lotus ornithopodioides

Lycopsis variegata

Malva mauritiana

Medicago arabica

Medicago truncatula

Melampyrum fimbriatum

Melilotus indica

Mentha longifolia subsp. longifolia

Mentha microphylla

Mentha pubescens

Mentha $\mathrm{x}$ dumetorum

Mentha $\mathrm{x}$ gentilis

Moehringia tommasinii

Myrtus communis

Ononis procurrens

Ononis pusilla

Ononis reclinata

Ophrys fusca

Orchis fragrans

Origanum vulgare subsp. viride

Ornithogalum refractum

Orobanche mutelii

Pallenis spinosa

Papaver argemone

Parapholis incurva

Parapholis strigosa

Paspalum distichum

Phalaris brachystachys

Phalaris minor

Phalaris paradoxa

Phillyrea latifolia

Phleum subulatum

Picnomon acarna

Puccinellia fasciculata

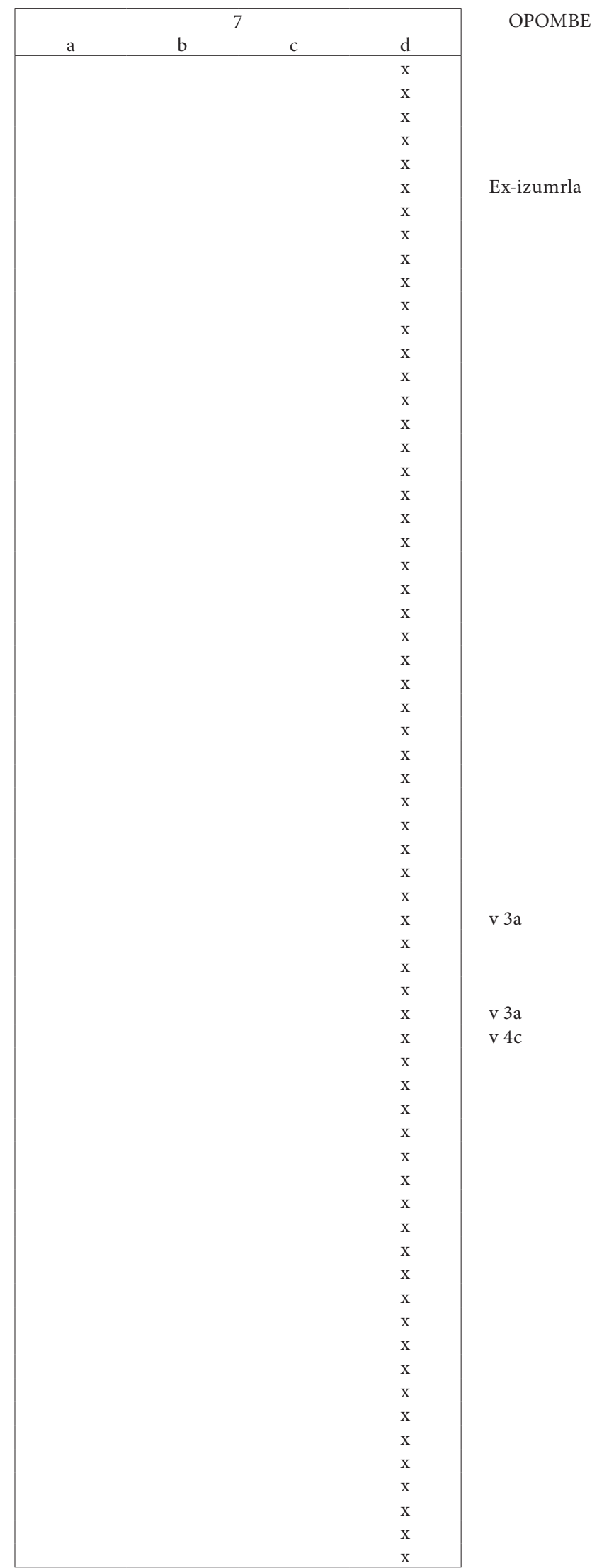


Pisum elatius

Plantago cornuti

Plantago coronopus

Polypogon monspeliensis

Posidonia oceanica

Potamogeton coloratus

Prospero elisae

Puccinellia palustris

Pyrus amygdaliformis

Ranunculus chius

Ranunculus ficaria subsp. ficariiformis

Ranunculus muricatus

Ranunculus neapolitanus

Ranunculus parviflorus

Reichardia picroides

Rhagadiolus stellatus

Rosa obtusifolia

Rubia peregrina

Rubia tinctorium

Ruppia maritima

Salicornia emerici

Salicornia patula

Salsola kali

Salsola soda

Salvia clandestina

Sarcocornia fruticosa

Scandix grandiflora

Schoenoplectus tabernaemontani

Seseli tortuosum

Sonchus maritimus

Spergularia marina

Spergularia media

Sternbergia lutea

Suaeda maritima

Tagetes minuta

Tamarix gallica

Teucrium polium

Tordylium apulum

Torilis nodosa

Tragus racemosus

Tribulus terrestris

Trifolium angustifolium

Trifolium cherleri

Trifolium dalmaticum

Trifolium lappaceum

Trifolium pratense subsp. expansum

Trifolium squarrosum

Trifolium subterraneum

Trifolium squamosum

Turgenia latifolia

Valerianella eriocarpa

Verbascum sinuatum

Viburnum tinus

Vicia hybrida

Vicia loiseleurii

Vicia onobrychioides

Vitex agnus-castus

Ziziphus jujuba

Zostera marina

Zostera noltii

\begin{tabular}{|c|c|c|c|c|}
\hline \multicolumn{4}{|c|}{7} & \multirow[t]{2}{*}{ OPOMBE } \\
\hline $\mathrm{a}$ & b & c & $\mathrm{d}$ & \\
\hline & & & $\mathrm{x}$ & \\
\hline & & & $\mathrm{x}$ & \\
\hline & & & $\mathrm{x}$ & \\
\hline & & & $\mathrm{x}$ & \\
\hline & & & $\mathrm{x}$ & \\
\hline & & & $\mathrm{x}$ & \\
\hline & & & $\mathrm{x}$ & $\mathrm{v} 4 \mathrm{~b}$ \\
\hline & & & $\mathrm{x}$ & \\
\hline & & & $\mathrm{x}$ & \\
\hline & & & $\mathrm{x}$ & \\
\hline & & & $\mathrm{x}$ & \\
\hline & & & $x$ & \\
\hline & & & $\mathrm{x}$ & $\mathrm{v} 4 \mathrm{c}$ \\
\hline & & & $\mathrm{x}$ & \\
\hline & & & $\mathrm{x}$ & \\
\hline & & & $\mathrm{x}$ & \\
\hline & & & $\mathrm{x}$ & \\
\hline & & & $\mathrm{x}$ & \\
\hline & & & $\mathrm{x}$ & \\
\hline & & & $\mathrm{x}$ & \\
\hline & & & $\mathrm{x}$ & \\
\hline & & & $\mathrm{x}$ & \\
\hline & & & $\mathrm{x}$ & \\
\hline & & & $\mathrm{x}$ & \\
\hline & & & $x$ & \\
\hline & & & $\mathrm{x}$ & \\
\hline & & & $\mathrm{x}$ & \\
\hline & & & $\mathrm{x}$ & v $3 a$ \\
\hline & & & $\mathrm{x}$ & \\
\hline & & & $\mathrm{x}$ & \\
\hline & & & $\mathrm{x}$ & \\
\hline & & & $\mathrm{x}$ & \\
\hline & & & $\mathrm{x}$ & \\
\hline & & & $\mathrm{x}$ & \\
\hline & & & $\mathrm{x}$ & \\
\hline & & & $\mathrm{x}$ & podivjana \\
\hline & & & $x$ & \\
\hline & & & $\mathrm{x}$ & \\
\hline & & & $\mathrm{x}$ & \\
\hline & & & $\mathrm{x}$ & \\
\hline & & & $\mathrm{x}$ & \\
\hline & & & $\mathrm{x}$ & \\
\hline & & & $\mathrm{x}$ & \\
\hline & & & $\mathrm{x}$ & \\
\hline & & & $\mathrm{x}$ & \\
\hline & & & $\mathrm{x}$ & \\
\hline & & & $\mathrm{x}$ & \\
\hline & & & $\mathrm{x}$ & \\
\hline & & & $\mathrm{x}$ & \\
\hline & & & $\mathrm{x}$ & $\mathrm{v} 4 \mathrm{~b}$ \\
\hline & & & $\mathrm{x}$ & \\
\hline & & & $\mathrm{x}$ & \\
\hline & & & $\mathrm{x}$ & \\
\hline & & & $\mathrm{x}$ & \\
\hline & & & $\mathrm{x}$ & \\
\hline & & & $\mathrm{x}$ & \\
\hline & & & $\mathrm{x}$ & \\
\hline & & & $\mathrm{x}$ & \\
\hline & & & $\mathrm{x}$ & \\
\hline & & & $\mathrm{x}$ & \\
\hline
\end{tabular}


Table 16: Biological forms of species of districts of the sub-Mediterranean phytogeographic area. Tabela 16: Biološke oblike vrst distriktov submediteranskega fitogeografskega območja.

Geofit

Terofit

Fanerofit

Hemokriptofit

Hamefit

Nanofanerofit

Hydrofit

\begin{tabular}{|cccc|}
\hline & 7 & & \\
$\mathrm{a}$ & $\mathrm{b}$ & $\mathrm{c}$ & $\mathrm{d}$ \\
\hline 1 & 8 & 1 & 18 \\
5 & 14 & 2 & 94 \\
4 & 5 & 0 & 14 \\
3 & 24 & 2 & 38 \\
1 & 2 & 0 & 10 \\
0 & 2 & 0 & 3 \\
0 & 1 & 0 & 7 \\
\hline
\end{tabular}


Table 17: Geoelements of districts of the sub-Mediterranean phytogeographic area. Tabela 17: Geoelementi distriktov submediteranskega fitogeografskega območja.

Eurimediteranski - Macron. / Eurimedit.-Macaron. Adv. sinatrop. / Adv. Sinantr.

Adv. naturaliziran / Adv. Natural.

Cosmopolit - Subtrop. / Cosmopol.-Subtrop.

Vzh. Evropski / E Eur.

Južno Evropski / S Eur.

Pontski / Pont.

Orof. Južno Evrop. / Orof. S Eur.

Jugovzhod. Evrop. / SE Eur.

Južno Stenomediter. / S Stenomedit.

Zahod. Mediteran. / W Medit.

Mediteransko - Mont. / Medit.-Mont.

Evroazijski - Sev. Am. - Avstral. / Eurasiat.-N Am.-Austr.

Evrimediteran. / Eurimedit.

Zahodnoevropski / W Eur.

Južnoevrop. - mont. / S Eur.-Mont.

Južnoevrop. - Južno Sibir. / S Eur.-S Sibir.

Endemit / Endem.

Severno Evropsko montan. / N Eur.-Mont.

Evropski / Eur.

Vzhodno alpski - Kavkaški / E Alp.-Cauc.

Evrosibirski / Eurosib.

Centralno Evropski / CE Eur.

Stenomediteranski - Atlantski / Stenomedit.-Atl.

Severovzhodno Mediter. - Mont. / NE Medit.-Mont.

Juž. Evrop. - Zahod. Azijski / S Eur.-W Asiat.

Evrimediter. - Turanski / Eurimedit.-Turan.

Mediteranski / Medit.

Evropski - Kavkaški / Eur.-Cauc.

Orof. Evropski / Orof. Eur.

Evroazijski / Eurasiat.

Paleotemperatni / Paleotemp.

Kozmopolit / Cosmop.

Azijski / Asiat.

Severovzhod. Evrimediter. / NE Eurimedit.

Stenomediteranski / Stenomedit.

Vzh. Evrop. - Azijski / E Eur.-Asiat.

Pantropski / Pantrop.

Evropsko - Subatlant. / Eur.-Subatl.

Subtropski / Subtrop.

Azijsko - Severnomediter. / Asiat.-N Medit.

Južnoilirski / S Illyr.

Cirkumborealni / Circumbor.

Centralno Eurimediteranski /Centr. Eurimedit.

Evrimediter. - Subatlantski / Eurimedit.-Subatl.

Jugozahod. Evrop. - Montanski / SW Eur.-Mont.

Vzhodno mediter. - Turanski / E Medit.-Turan.

Vzhodno mediter. - Atlantski/ E Medit.-Atl.

Subkozmopolitski / Subcosmopol.

Zahodno Stenomediter. / W Stenomedit.

Severovzhodno mediter. - mont. / NE Medit.-Mont.

Vzhodnoevropsko - mont. / E Eur.-Mont.

Termokozmopolit / Termocosmopol.

\begin{tabular}{|c|c|c|c|}
\hline \multicolumn{4}{|c|}{7} \\
\hline a & $\mathrm{b}$ & c & $\mathrm{d}$ \\
\hline 1 & & & \\
\hline 2 & & & \\
\hline 4 & 1 & & 6 \\
\hline 1 & & & \\
\hline 1 & 1 & & \\
\hline 2 & 1 & & \\
\hline 1 & & & 1 \\
\hline 1 & 2 & & 1 \\
\hline 1 & 9 & & 4 \\
\hline & 1 & & \\
\hline & 1 & & \\
\hline & 2 & & 4 \\
\hline & 1 & & \\
\hline & 5 & & 46 \\
\hline & 2 & & 2 \\
\hline & 3 & 1 & \\
\hline & 1 & & 6 \\
\hline & 6 & & 1 \\
\hline & 1 & & \\
\hline & 2 & & 5 \\
\hline & 1 & & \\
\hline & 1 & & 2 \\
\hline & 1 & & \\
\hline & 1 & & 4 \\
\hline & 1 & & 2 \\
\hline & 2 & & 1 \\
\hline & 2 & & 9 \\
\hline & 2 & & 2 \\
\hline & 1 & 1 & \\
\hline & 1 & & \\
\hline & 1 & & 4 \\
\hline & 1 & & 4 \\
\hline & 1 & & 4 \\
\hline & 1 & & \\
\hline & 1 & & \\
\hline & 1 & & 39 \\
\hline & & 1 & \\
\hline & & & 1 \\
\hline & & & 2 \\
\hline & & & 7 \\
\hline & & & 1 \\
\hline & & & 1 \\
\hline & & & 2 \\
\hline & & & 1 \\
\hline & & & 4 \\
\hline & & & 1 \\
\hline & & & 1 \\
\hline & & & 1 \\
\hline & & & 4 \\
\hline & & & 1 \\
\hline & & & 1 \\
\hline & & & 1 \\
\hline & & & 1 \\
\hline
\end{tabular}


Table 18: List of plant species that thrive exclusively or mostly in districts of the sub-Pannonic phytogeographic area. Tabela 18: Seznam rastlinskih vrst, ki izključno ali večinoma uspevajo v distriktih subpanonskega fitogeografskega območja.

Anemone sylvestris

Apera spica-venti

Aphanes arvensis

Arnoseris minima

Arum alpinum

Atriplex oblongifolia

Berteroa incana

Bryonia alba

Butomus umbellatus

Caldesia parnassifolia

Ceratophyllum submersum

Chenopodium botrys

Chenopodium foliosum

Chenopodium murale

Chenopodium pedunculare

Chenopodium rubrum

Cyperus michelianus

Daphne cneorum var. arborea

Elatine hexandra

Elatine triandra

Epipactis nordeniorum

Epipactis voethii

Euphorbia palustris

Euphorbia segetalis

Gagea pratensis

Gagea spathacea

Cerastium dubium

Gnaphalium luteoalbum

Hieracium leptophyton

Hydrocharis morsus-ranae

Lemna trisulca

Leonurus marrubiastrum

Lindernia dubia

Luzula divulgata

Moenchia mantica subsp. caerulea

Myosurus minimus

Nymphoides peltata

Omphalodes scorpioides

Papaver dubium

Potamogeton acutifolius

Potentilla supina

Pulmonaria mollissima

Rubus graecensis

Rubus weizensis

Rumex kerneri

Rumex longifolius

Rumex maritimus

Rumex palustris

Rumex stenophyllus

Saxifraga bulbifera

Spergularia rubra

Scirpus radicans

Stratiotes aloides

Typha laxmannii

Typha minima

Veronica triphyllos

Viscum laxum

Vulpia bromoides

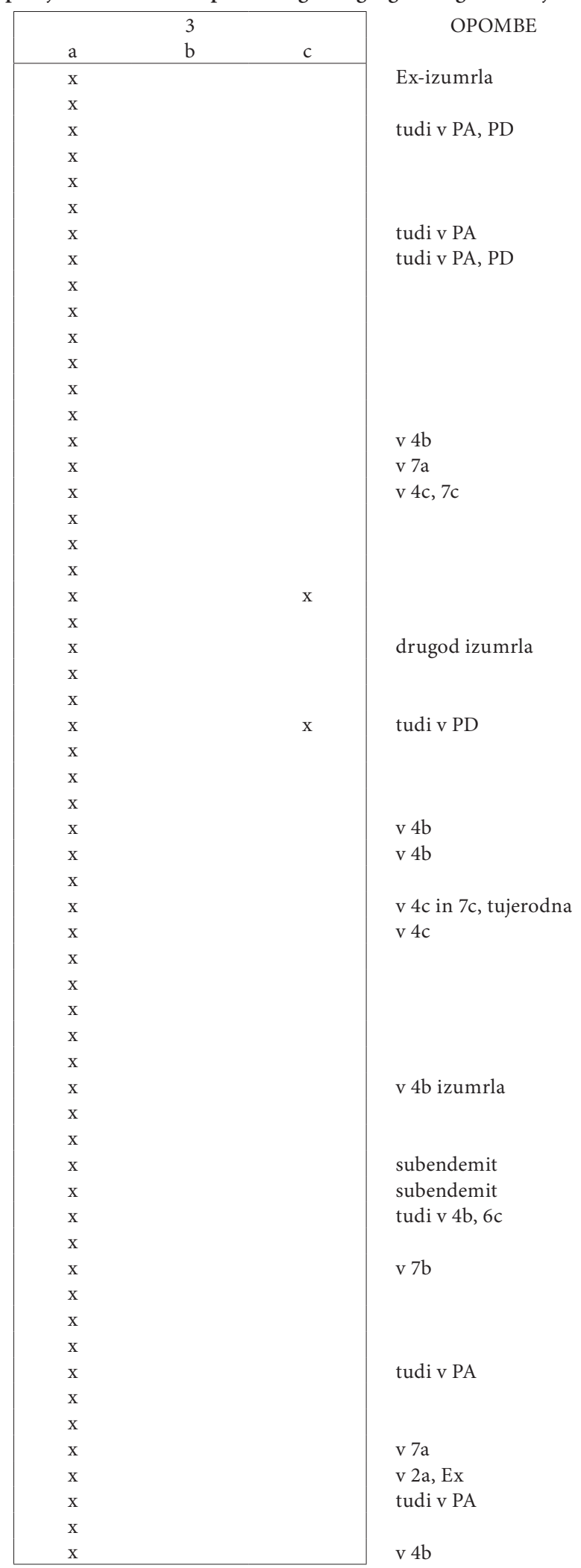


Apium repens

Dianthus plumarius subsp. hoppei

Montia fontana

Potamogeton obtusifolius

Pulsatilla grandis

Scorzonera cana

Sempervivum juvanii

Sicyos angulatus

Artemisia abrotanum

Cyperus longus

Moehringia bavarica

Scutellaria altissima

\begin{tabular}{|c|c|c|}
\hline \multirow[t]{13}{*}{$\mathrm{a}$} & $\begin{array}{l}3 \\
b\end{array}$ & c \\
\hline & $\mathrm{x}$ & \\
\hline & $\mathrm{x}$ & \\
\hline & $\mathrm{x}$ & \\
\hline & $\mathrm{x}$ & \\
\hline & $\mathrm{x}$ & \\
\hline & $x$ & \\
\hline & $\mathrm{x}$ & \\
\hline & $\mathrm{x}$ & \\
\hline & & $\mathrm{x}$ \\
\hline & & $\mathrm{x}$ \\
\hline & & $\mathrm{x}$ \\
\hline & & $\mathrm{x}$ \\
\hline
\end{tabular}

OPOMBE

endemit

v 4a, tujerodna

v $7 b$

Ex-izumrla

Table 19: Biological forms of species of districts of the sub-Pannonic phytogeographic area.

Tabela 19: Biološke oblike vrst distriktov subpanonskega fitogeografskega območja.

Hemikriptofit

Terofit

Geofit

Hidrofit

Hamefit

Nanofanerofit

Fanerofit

\begin{tabular}{|ccc|}
\hline & 3 & $c$ \\
\hline 10 & $b$ & 2 \\
24 & 5 & \\
6 & 2 & \\
6 & 1 & \\
4 & & \\
2 & & \\
1 & & \\
\hline
\end{tabular}

Table 20: Geoelements of districts of the sub-Pannonic phytogeographic area. Tabela 20: Geoelementi distriktov subpanonskega fitogeografskega območja.

Eurosibirski / Eurosib.

Subkozmopolitski / Subcosmopol.

Evropski / Eur.

Južnoevropski / S Eur.

Pontski / Pont.

Južnoevrop.-južno Sibir. / S Eur.-S Sib.

Evroazijatski / Eurasiat.

Subtropski / Subtrop.

Paleosubtropski / Paleosubtrop.

Orof. Južnoevropski / Orof. S Eur.

Cirkumborealni / Circumbor.

Severnoameriški / N Am.

Stenomediteranski / Stenomedit.

Kozmopolitski / Cosmopol.

Adv. Naturaliziran / Adv. Natural.

Vzhodnoevropski / E Eur.

Severnomediter.-montan. / N Medit.-Mont.

Evrimediter.-Turanski / Eurimedit.-Tur.

Centralnoevropski / CE Eur.

Jugovzhod. centr. Evrop. / SE-CE Eur.

Jugovzhodnoevropski / SE Eur.

Evropsko-Kavkaški / Eur.-Cauc.

Vzhodnomediteranski / E Medit.

Paleotemperatni / Paleotemp.

Vzhodnoevrop.-Karpatski / E Eur.-Carp.

Arktično-Alpski / Arct.-Alp.

Endemit / Endem.

Vzhodnoalpsko-dinarski / E Alp.-Din.

\begin{tabular}{|c|c|c|}
\hline $\mathrm{a}$ & $\begin{array}{l}3 \\
b\end{array}$ & c \\
\hline 5 & & \\
\hline 6 & & \\
\hline 2 & 1 & \\
\hline 2 & & \\
\hline 1 & & \\
\hline 5 & & \\
\hline 8 & & \\
\hline 4 & & \\
\hline 1 & & \\
\hline 1 & & 1 \\
\hline 1 & & \\
\hline 2 & & \\
\hline 1 & & \\
\hline 1 & & \\
\hline 1 & 1 & \\
\hline 2 & 1 & \\
\hline 1 & & \\
\hline 1 & & \\
\hline 1 & 1 & \\
\hline 1 & & \\
\hline 1 & 1 & 1 \\
\hline 1 & & \\
\hline 1 & & \\
\hline 1 & & \\
\hline & 1 & \\
\hline & 1 & \\
\hline & 1 & \\
\hline & & 1 \\
\hline
\end{tabular}


Table 21: Percentage share of biological forms in the phytogeographic areas of Slovenia.

Tabela 21: Odstotni delež bioloških oblik v fitogeografskih območjih Slovenije.

Fanerofiti

Hemikriptofiti

Hamefiti

Geofiti

Terofiti

Hidrofiti

SKUPNO

\begin{tabular}{|cc|cc|cc|cc|cc|cc|c|}
\hline \multicolumn{2}{|c}{ ALP } & \multicolumn{2}{c}{ PALP } & \multicolumn{2}{c}{ DIN } & \multicolumn{2}{c}{ PDIN } & \multicolumn{2}{c}{ SUBM } & \multicolumn{2}{c|}{ SUBP } & \multicolumn{2}{c|}{ SKUPNO } \\
$\%$ & št. & $\%$ & št. & $\%$ & št. & $\%$ & št. & $\%$ & št. & $\%$ & št. & št. \\
\hline 0 & 0 & 19 & 9 & 11 & 5 & 4 & 2 & 60 & 28 & 6 & 3 & 47 \\
13 & 25 & 33 & 65 & 9 & 17 & 2 & 4 & 34 & 67 & 9 & 17 & 195 \\
20 & 7 & 26 & 9 & 9 & 3 & 0 & 0 & 35 & 13 & 14 & 5 & 37 \\
8 & 5 & 30 & 19 & 5 & 3 & 2 & 1 & 45 & 28 & 10 & 6 & 62 \\
1 & 1 & 14 & 25 & 3 & 5 & 1 & 2 & 66 & 115 & 15 & 26 & 174 \\
0 & 0 & 36 & 5 & 7 & 1 & 0 & 0 & 57 & 8 & 39 & 7 & 21 \\
\hline 42 & 38 & 158 & 132 & 44 & 34 & 9 & 9 & 297 & 259 & 93 & 64 & 536 \\
\hline
\end{tabular}

Oznake območij / Area abbreviations:

ALP - alpsko / Alpine

PALP - predalpsko pre-Alpine

DIN - dinarsko / Dinaric

PDIN - preddinarsko / pre-Dinaric

SUBM - submediteransko / sub-Mediterranean

SUBP - subpanonsko / sub-Pannonian

Table 22: Percentage share of biological forms in specific phytogeographic areas of Slovenia.

Tabela 22: Odstotni delež bioloških oblik v določenem fitogeografskem območju Slovenije.

Fanerofiti

Nanofanerofiti

Hemikriptofiti

Hamefiti

Geofiti

Terofiti

Helofiti

Hidrofiti

SKUPNO

\begin{tabular}{|cc|cc|cc|cc|cc|cc|}
\hline \multicolumn{2}{|c|}{ ALP } & \multicolumn{2}{c|}{ PALP } & \multicolumn{2}{c|}{ DIN } & \multicolumn{2}{c|}{ PDIN } & \multicolumn{2}{c|}{ SUBM } & \multicolumn{2}{c|}{ SUBP } \\
$\%$ & št. & $\%$ & št. & $\%$ & št. & $\%$ & št. & $\%$ & št. & $\%$ & št. \\
\hline 0 & 0 & 6 & 8 & 12 & 4 & 22 & 2 & 9 & 23 & 1 & 1 \\
0 & 0 & 1 & 1 & 3 & 1 & 0 & 0 & 2 & 5 & 3 & 2 \\
66 & 25 & 49 & 65 & 50 & 17 & 44 & 4 & 26 & 67 & 27 & 17 \\
18 & 7 & 6 & 9 & 9 & 3 & 0 & 0 & 5 & 13 & 8 & 5 \\
13 & 5 & 14 & 19 & 9 & 3 & 12 & 1 & 11 & 28 & 9 & 6 \\
3 & 1 & 19 & 25 & 14 & 5 & 22 & 2 & 44 & 115 & 41 & 26 \\
0 & 0 & 2 & 2 & 3 & 1 & 0 & 0 & 0 & 0 & 0 & 0 \\
0 & 0 & 2 & 3 & 0 & 0 & 0 & 0 & 3 & 8 & 11 & 7 \\
\hline 100 & 38 & 92 & 123 & 85 & 29 & 78 & 7 & 89 & 231 & 96 & 61 \\
\hline
\end{tabular}

Oznake območij / Area abbreviations:

ALP - alpsko / Alpine

PALP - predalpsko pre-Alpine

DIN - dinarsko / Dinaric

PDIN - preddinarsko / pre-Dinaric

SUBM - submediteransko / sub-Mediterranean

SUBP - subpanonsko / sub-Pannonian 
Table 23: Percentage share of geoelements of exclusive or mainly present species in the phytogeographic areas of Slovenia. Tabela 23: Odstotni delež geolementov izključno ali večinoma prisotnih vrst $\mathbf{v}$ fitocenoloških območjih Slovenije.

Vzhodnoalp.-ilirski endemiti / E Alp.-Illyr. Endem. Alpski endemiti / Alp. Endem.

Orof. jugozahodno evropski / Orof. SW Eur.

Vzhodnoalpsko-karpatski / E Alp.-Carp.

Vzhodnoalpski / E Alp.

Jugovzhodnoevropski - montanski / SE Europ.-Mont.

Cirkumborealni-arktično-alpski / Circumboreal.-Arct.-Alp.

Endemiti / Endem.

Arktično alpski / Arct.-Alp.

Jugovzhodnoevropski / SE Eur.

Orof. južnoevropski / Orof. S Eur.

Centralnoalpski / Centr. Alp.

Cirkumborealni / Circumbor.

Eurimediteranski / Eurimedit.

Evropsko-kavkaški / Eur.-Cauc.

Vzhodnoazijski / E Asiat.

Severnoameriški / N Am.

Naturalizirani / Nat.

Alpsko-apeninski / Alp.-Apen.

Jugovzhodno centralnoevropski / SE Centr. Eur.

Evrosibirsko-severnoameriški / Eurosib.-N Amer.

Jugovzhodnoevropski-jugozahod. azijski / SE Eur.-SW Asiat.

Orof. evropsko-azijski / Orof. Eurasiat.

Subatlantski / Subatl.

Južnoameriški / S Am.

Južnoevropsko-mediteranski / S Eur.-Medit.

Centralnoevropsko-severnoameriški / Centr. Eur.-N Am.

Severnoevropski / N Eur.

Vzhodno evrimediteranski / E Eurimedit.

Centralno evrosibirski / Centr. Eurosib.

Evropski montanski / Eur.-Mont.

Mediteransko-turanski / Medit.-Turan.

Ilirski / Illyr.

Evropski / Eur.

Evropsko-azijski / Eurasiat.

Jugozahodno evropski / SW Eur.

Orof. Centralnoevropski / Orof. Centr. Eur.

Mediteransko-zahodnoazijski / Medit.-W Asiat.

Evrimediteranski / Eurimedit.

Severovzhod. mediter.-montanski / NE Medit.-Mont.

Stenomediteranski-montanski / Stenomedit.-Mont.

Zahodnoevropski / W Eur.

Južnoevropski-montanski / S Eur.-Mont.

Adv. sinantropski / Adv. Sinantrop.

Jugozahodnoazijski / SW Asiat.

Kozmopolit - subtropski / Cosmopol.-Subtrop.

Vzhodnomediteranski-montanski / E Medit.-Mont.

Zahodno eumediteranski / W Eumedit.

Južnoilirski / S Illyr.

Neotropski / Neotrop.

Orof. Evropski / Orof. Eur.

Severno stenomediteranski / N Stenomedit.

Vzhodno stenomediteranski / E Stenomedit.

Zahodno stenomediteranski / W Stenomedit.

Eurimediteransko-makaronski / Eurimedit.-Macaron. Južno stenomediteranski / S Stenomedit.

Severovzhodnoevropski - montanski / NE Eur.-Mont.

Centralnoazijski / Centr. Asiat.

Jugozahodnoevropski-montanski / SE Eur.-Mont.

\begin{tabular}{|c|c|c|c|c|c|c|c|c|c|c|c|}
\hline \multicolumn{2}{|c|}{ ALP } & \multicolumn{2}{|c|}{ PALP } & \multicolumn{2}{|c|}{ DIN } & \multicolumn{2}{|c|}{ PDIN } & \multicolumn{2}{|c|}{ SUBM } & \multicolumn{2}{|c|}{ SUBP } \\
\hline$\%$ & št. & $\%$ & št. & $\%$ & št. & $\%$ & št. & $\%$ & št. & $\%$ & št. \\
\hline 100 & 1 & & & & & & & & & & \\
\hline 62 & 5 & 25 & 2 & 13 & 1 & & & & & & \\
\hline 50 & 1 & 50 & 1 & & & & & & & & \\
\hline 50 & 1 & & & & & & & & & 50 & 1 \\
\hline 40 & 2 & 40 & 2 & & & & & & & 20 & 1 \\
\hline 38 & 3 & 38 & 3 & & & & & 25 & 2 & & \\
\hline 40 & 2 & 60 & 3 & & & & & & & & \\
\hline 29 & 8 & 25 & 7 & 11 & 3 & & & 32 & 9 & 3 & 1 \\
\hline 25 & 1 & 50 & 2 & & & & & & & 25 & 1 \\
\hline 9 & 3 & 30 & 10 & 9 & 3 & 3 & 1 & 43 & 14 & 6 & 2 \\
\hline 23 & 3 & 46 & 6 & & & & & 31 & 4 & & \\
\hline 22 & 3 & 50 & 7 & 7 & 1 & & & 7 & 1 & 14 & 2 \\
\hline 17 & 2 & 50 & 6 & 8 & 1 & & & 17 & 2 & 8 & 1 \\
\hline & & 50 & 2 & 25 & 1 & & & 25 & 1 & & \\
\hline & & 50 & 3 & & & & & 33 & 2 & 17 & 1 \\
\hline & & 67 & 2 & & & & & & & 33 & 1 \\
\hline & & 80 & 4 & & & & & & & 20 & 1 \\
\hline & & 86 & 6 & & & & & 14 & 1 & & \\
\hline & & 100 & 1 & & & & & & & & \\
\hline & & 50 & 1 & & & & & & & 50 & 1 \\
\hline & & 100 & 2 & & & & & & & & \\
\hline & & 100 & 1 & & & & & & & & \\
\hline & & 100 & 1 & & & & & & & & \\
\hline & & 100 & 2 & & & & & & & & \\
\hline & & 100 & 1 & & & & & & & & \\
\hline & & 100 & 1 & & & & & & & & \\
\hline & & 100 & 1 & & & & & & & & \\
\hline & & 100 & 1 & & & & & & & & \\
\hline & & 100 & 1 & & & & & & & & \\
\hline & & 100 & 1 & & & & & & & & \\
\hline & & & & 100 & 1 & & & & & & \\
\hline & & & & 100 & 1 & & & & & & \\
\hline & & & & 67 & 2 & 33 & 1 & & & & \\
\hline & & & & 54 & 15 & 3 & 1 & 25 & 7 & 18 & 5 \\
\hline & & & & 44 & 11 & 8 & 2 & 20 & 5 & 28 & 7 \\
\hline & & & & & & 100 & 1 & & & & \\
\hline & & & & & & 100 & 1 & & & & \\
\hline & & & & & & 100 & 1 & & & & \\
\hline & & & & & & & & 100 & 49 & & \\
\hline & & & & & & & & 100 & 5 & & \\
\hline & & & & & & & & 100 & 5 & & \\
\hline & & & & & & & & 100 & 3 & & \\
\hline & & & & & & & & 100 & 3 & & \\
\hline & & & & & & & & 100 & 2 & & \\
\hline & & & & & & & & 100 & 2 & & \\
\hline & & & & & & & & 100 & 2 & & \\
\hline & & & & & & & & 100 & 4 & & \\
\hline & & & & & & & & 100 & 2 & & \\
\hline & & & & & & & & 100 & 1 & & \\
\hline & & & & & & & & 100 & 1 & & \\
\hline & & & & & & & & 100 & 1 & & \\
\hline & & & & & & & & 100 & 1 & & \\
\hline & & & & & & & & 100 & 1 & & \\
\hline & & & & & & & & 100 & 1 & & \\
\hline & & & & & & & & 100 & 1 & & \\
\hline & & & & & & & & 100 & 1 & & \\
\hline & & & & & & & & 100 & 1 & & \\
\hline & & & & & & & & 100 & 1 & & \\
\hline & & & & & & & & 100 & 1 & & \\
\hline
\end{tabular}


Termokozmopolit / Termocosmopol.

Centralnoevmediteranski / Centr. Eurimedit.

Evrimediteranski-atlantski / Eurimedit.-Atl

Evrimediteranski-turanski / Eurimedit.-Tur.

Stenomediteranski / Stenomedit.

Subtropski / Subtrop.

Adv. naturalizirani / Adv. Natur.

Mediteranski / Medit.

Evrimediteranski-subatlantski / Eurimedit.-Subatl.

Mediteransko-montanski / Medit.-Mont.

Pontski / Pont.

Kozmopoliti / Cosmopol.

Paleotemperatni / Paleotemp.

Vzhodnoevropski / E Eur.

Južnoevropski / S Eur.

Južnoevropski-južnosibirski / S Eur.-S Sib.

Evropski-sibirski / Eur.-Sib.

Subkozmopoliti / Subcosmopol.

Ameriški / Am.

Paleotropski / Paleotrop.

Pantropski / Pantrop.

Severozahodno evrimediteranski / NW Eurimedit.

Vzhodnomediteranski / E Medit.

Vzhodnoalpski-ilirski / E Alp.-Illyr.

\begin{tabular}{|c|c|c|c|c|c|c|c|c|c|c|c|}
\hline \multicolumn{2}{|c|}{ ALP } & \multicolumn{2}{|c|}{ PALP } & \multicolumn{2}{|c|}{$\mathrm{DIN}$} & \multicolumn{2}{|c|}{ PDIN } & \multicolumn{2}{|c|}{ SUBM } & \multicolumn{2}{|c|}{ SUBP } \\
\hline$\%$ & št. & $\%$ & št. & $\%$ & št. & $\%$ & št. & $\%$ & št. & $\%$ & št. \\
\hline & & & & & & & & 100 & 1 & & \\
\hline & & & & & & & & 100 & 1 & & \\
\hline & & & & & & & & 100 & 1 & & \\
\hline & & & & & & & & 92 & 11 & 8 & 1 \\
\hline & & & & & & & & 90 & 37 & 3 & 1 \\
\hline & & & & & & & & 88 & 7 & 12 & 1 \\
\hline & & & & & & & & 83 & 10 & 17 & 2 \\
\hline & & 20 & 1 & & & & & 80 & 4 & & \\
\hline & & 25 & 2 & & & & & 75 & 6 & & \\
\hline & & & & & & & & 75 & 3 & 25 & 1 \\
\hline & & & & & & & & 67 & 2 & 33 & 1 \\
\hline & & 17 & 1 & & & & & 66 & 4 & 17 & 1 \\
\hline & & 25 & 2 & & & & & 63 & 5 & 12 & 1 \\
\hline & & 20 & 1 & & & & & 60 & 3 & 20 & 1 \\
\hline & & & & 9 & 1 & 9 & 1 & 55 & 6 & 27 & 3 \\
\hline & & 19 & 3 & 6 & 1 & & & 44 & 7 & 31 & 5 \\
\hline & & 28 & 5 & 6 & 1 & & & 22 & 4 & 44 & 8 \\
\hline 10 & 1 & & & & & & & 30 & 3 & 60 & 6 \\
\hline & & & & & & & & & & 100 & 1 \\
\hline & & & & & & & & & & 100 & 1 \\
\hline & & & & & & & & & & 100 & 1 \\
\hline & & & & & & & & & & 100 & 1 \\
\hline & & & & & & & & & & 100 & 1 \\
\hline & & & & & & & & & & 100 & 1 \\
\hline
\end{tabular}

Oznake območij / Area abbreviations:

ALP - alpsko / Alpine

PALP - predalpsko pre-Alpine

DIN - dinarsko / Dinaric

PDIN - preddinarsko / pre-Dinaric

SUBM - submediteransko / sub-Mediterranean

SUBP - subpanonsko / sub-Pannonian 
Table 24: Percentage share of geoelements of exclusive or mainly present species in specific phytogeographic areas of Slovenia. Tabela 24: Odstotni delež geolementov izključno ali večinoma prisotnih vrst v določenem fitogeografskem območju Slovenije.

Endemiti / Endem.

Alpski endemiti / Alp. Endem.

Orof. južnoevropski / Orof. S Europ.

Centralnoevropski / Centr. Europ.

Jugovzhodnoevropski-montanski / SE Europ.-Mont.

Orof. Jugovzhodno evropski / Orof. SE Europ.

Cirkumborealni / Circumboreal.

Cirkumborealni-arktično-alpski / Circumboreal.-Arct.-Alp.

Vzhodnoalpski / E Alp.

Arktično alpski / Arct.-Alp.

Arktično-alpsko-evropski / Arct.-Alp.-Europ.

Vzhodnoalpsko-ilirski endemiti / E Alp-Illyr. Endem.

Orof. jugozahodno evropski / Orof. SW Europ.

Subkozmopoliti / Subcosmop.

Vzhodnoalpsko-karpatski / E Alp.-Carp.

Alpsko-apeninski / Alp. Apen.

Centralnovzhodnoalpsko-ilirski / Centr.-E Alp.-Illyr.

Jugovzhodnoevropski-jugozahod.azijski / SE Europ.-SW Asiat. Kozmopoliti / Cosmop.

Mediteranski / Medit.

Orof. evropsko-azijski / Orof. Europ.-Asiat.

Vzhodnoevropski / E Europ.

Južnoameriški / S Amer.

Južnoevrimediteranski / S Eurimedit.

Centralnoevropski-severnoameriški / Centr. Europ.-N Amer.

Severnoevropski / N Europ.

Vzhodno evrimediteranski / E Eurimediter.

Centralnosibirski / Centr. Sib.

Severnoevrimediteranski / N Eurimedit.

Evropsko-mediteranski / Europ. Medit.

Evrimediteransko-subatlantski / Eurimedit.-Subatlant.

Evrosibirsko-severnoameriški / Eurosib.-N Amer.

Paleotemperatni / Paleotemp.

Subatlantski / Subatlant.

Vzhodnoazijski / E Asiat.

Evropsko-kavkaški / Erop.-Caucas.

Južnoevropski-južnosibirski / S Europ.-S Sibir.

Stenomediteranski /Stenomedit.

Severnoameriški / N Amer.

Jugovzhodnoevropski / SE Europ.

Evropsko-sibirski / Europ.-Sib.

Naturalizirani / Naturaliz.

Evropsko-azijski / Europ.-Asiat.

Evropski / Europ.

Ilirski / Illyr.

Evropski-montanski / Europ.-Mont.

Južnoevropski / S Europ.

Mediteransko-turanski / Medit.-Turan.

Jugozahodno evropski / SW Europ.

Mediteransko-zahodnoazijski / Medit.-W Asiat.

Orof. Centralnoevropski / Orof. Centr. Europ.

Evrimediteranski / Eurimedit.

Evrimediteranski-turanski / Eurimedit.-Turan.

Avv. naturalizirani / Adv. Natural.

Subtropski / Subtrop.

Stenomediteranski-atlantski / Stenomedit.-Atlant

Severovzhod. mediter.-montanski / NE Medit.-Mont.

Južnoevropsko-montanski / SE Europ.-Mont.

Mediteransko-montanski / Medit.-Mont.

\begin{tabular}{|c|c|c|c|c|c|c|c|c|c|c|c|}
\hline \multicolumn{2}{|c|}{ ALP } & \multicolumn{2}{|c|}{ PALP } & \multicolumn{2}{|c|}{ DIN } & \multicolumn{2}{|c|}{ PDIN } & \multicolumn{2}{|c|}{ SUBM } & \multicolumn{2}{|c|}{ SUBP } \\
\hline$\%$ & št. & $\%$ & št. & $\%$ & št. & $\%$ & št. & $\%$ & št. & $\%$ & št. \\
\hline 22 & 8 & 6 & 7 & 15 & 33 & & & 4 & 9 & 2 & 1 \\
\hline 14 & 5 & 2 & 2 & 5 & 1 & & & & & & \\
\hline 8 & 3 & 5 & 6 & & & & & 2 & 4 & & \\
\hline 8 & 3 & 6 & 7 & 5 & 1 & & & 0 & 1 & 3 & 2 \\
\hline 8 & 3 & 2 & 3 & & & & & 0 & 2 & & \\
\hline 8 & 3 & 5 & 6 & 10 & 2 & & & 0 & 2 & & \\
\hline 5 & 2 & 5 & 6 & 5 & 1 & & & 0 & 2 & 2 & 1 \\
\hline 5 & 2 & 2 & 3 & & & & & & & & \\
\hline 5 & 2 & 2 & 2 & & & & & 0 & 1 & & \\
\hline 3 & 1 & 2 & 2 & & & & & & & 2 & 1 \\
\hline 3 & 1 & & & & & & & & & & \\
\hline 3 & 1 & & & & & & & & & & \\
\hline 3 & 1 & 0 & 1 & & & & & & & & \\
\hline 3 & 1 & & & & & & & 1 & 3 & 10 & 6 \\
\hline 3 & 1 & & & & & & & & & 2 & 1 \\
\hline & & 0 & 1 & & & & & & & & \\
\hline & & 0 & 1 & & & & & & & & \\
\hline & & 0 & 1 & & & & & & & & \\
\hline & & 0 & 1 & & & & & 2 & 4 & 2 & 1 \\
\hline & & 0 & 1 & & & & & 2 & 4 & & \\
\hline & & 0 & 1 & & & & & & & & \\
\hline & & 0 & 1 & & & & & 1 & 3 & & \\
\hline & & 0 & 1 & & & & & & & & \\
\hline & & 0 & 1 & & & & & & & & \\
\hline & & 0 & 1 & & & & & & & & \\
\hline & & 0 & 1 & & & & & & & & \\
\hline & & 0 & 1 & & & & & & & & \\
\hline & & 0 & 1 & & & & & & & & \\
\hline & & 0 & 1 & & & & & 0 & 1 & & \\
\hline & & 2 & 2 & 5 & 1 & & & 0 & 1 & & \\
\hline & & 2 & 2 & & & & & 2 & 6 & & \\
\hline & & 2 & 2 & & & & & & & & \\
\hline & & 2 & 2 & & & & & 2 & 5 & 2 & 1 \\
\hline & & 2 & 2 & & & & & & & & \\
\hline & & 2 & 2 & & & & & & & 2 & 1 \\
\hline & & 2 & 3 & & & & & 0 & 2 & 2 & 1 \\
\hline & & 2 & 3 & 5 & 1 & & & 3 & 7 & 9 & 5 \\
\hline & & 2 & 3 & & & & & 14 & 37 & 2 & 1 \\
\hline & & 3 & 4 & & & & & & & 2 & 1 \\
\hline & & 3 & 4 & 5 & 1 & 17 & 1 & 5 & 12 & 3 & 2 \\
\hline & & 4 & 5 & 5 & 1 & & & 2 & 4 & 7 & 4 \\
\hline & & 5 & 6 & & & & & 0 & 1 & & \\
\hline & & 9 & 11 & 10 & 2 & & & 2 & 5 & 12 & 7 \\
\hline & & 12 & 15 & 5 & 1 & & & 3 & 7 & 9 & 5 \\
\hline & & & & 10 & 2 & 17 & 1 & & & & \\
\hline & & & & 5 & 1 & & & & & & \\
\hline & & & & 5 & 1 & 17 & 1 & 2 & 6 & 5 & 3 \\
\hline & & & & 5 & 1 & & & & & & \\
\hline & & & & & & & 1 & & & & \\
\hline & & & & & & & 1 & & & & \\
\hline & & & & & & 17 & 1 & & & & \\
\hline & & & & & & & & 19 & 49 & & \\
\hline & & & & & & & & 4 & 11 & 2 & 1 \\
\hline & & & & & & & & 4 & 10 & 3 & 2 \\
\hline & & & & & & & & 3 & 7 & 2 & 1 \\
\hline & & & & & & & & 2 & 5 & & \\
\hline & & & & & & & & 2 & 5 & & \\
\hline & & & & & & & & 1 & 3 & & \\
\hline & & & & & & & & 1 & 3 & 2 & 1 \\
\hline
\end{tabular}


Zahodnoevropski / W Europ.

Vzhodnomediteranski-montanski / E Medit.-Mont. Zahodno eurimediteranski / W Eurimedit. Jugozahodnoazijski / SW Asiat. Pontski / Pont.

Kozmopoliti-subtropski / Cosmop.-Subtrop. Adv. subtropski / Adv. Subtrop. Južno stenomediteranski / S Stenomedit. Zahodno stenomediteranski / W Stenomedit. Vzhodno stenomediteranski / E Stenomedit. Severno stenomediteranski /N Stenomedit.

Eurimediteransko-makaronski / Eurimedit.-Macaron. Evrimediteransko-atlantski / Eurimedit.-Atlant. Centralnoevromediteranski / Centr. Euromedit. Severovzhodnoevropski - mediteranski / NE Eur.-Medit. Jugovzhodnoevropski - montanski / SE Europ.-Mont. Južnoilirski/ S Illyr.

Centralnoazijski / Centr. Asiat.

Pantropski / Pantrop.

Orof. Evropski/ Orof. Europ.

Termokozmopolit / Termocosmop.

Neotropski / Neotrop.

Vzhodnomediteranski / E Medit.

Jugovzhodno centralnoevropski / SE Cenr. Europ.

Vzhodnoalpsko-ilirski / E Alp.-Illyr.

Paleosubtropski / Paleosubtr.

Severozahodno evrimediteranski / NE Eurimedit. Ameriški / Amer.

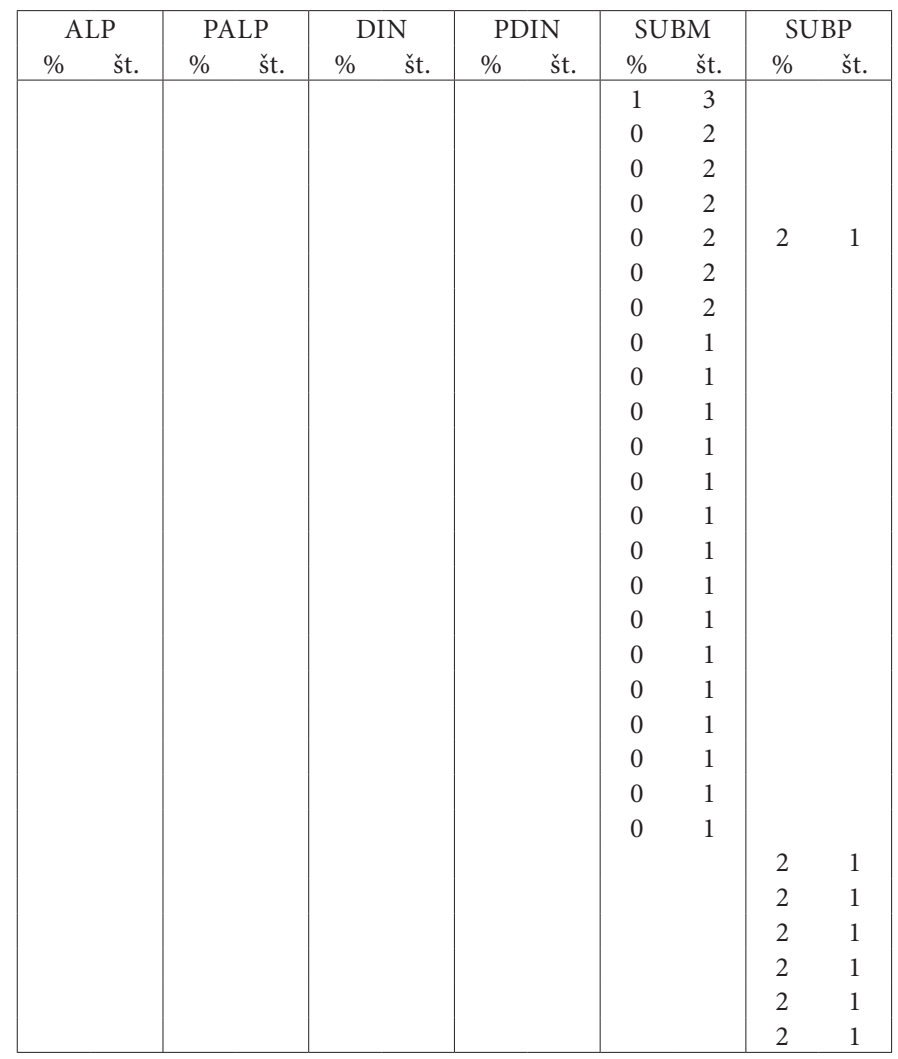

Oznake območij / Area abbreviations:

ALP - alpsko / Alpine

PALP - predalpsko pre-Alpine

DIN - dinarsko / Dinaric

PDIN - preddinarsko / pre-Dinaric

SUBM - submediteransko / sub-Mediterranean

SUBP - subpanonsko / sub-Pannonian 

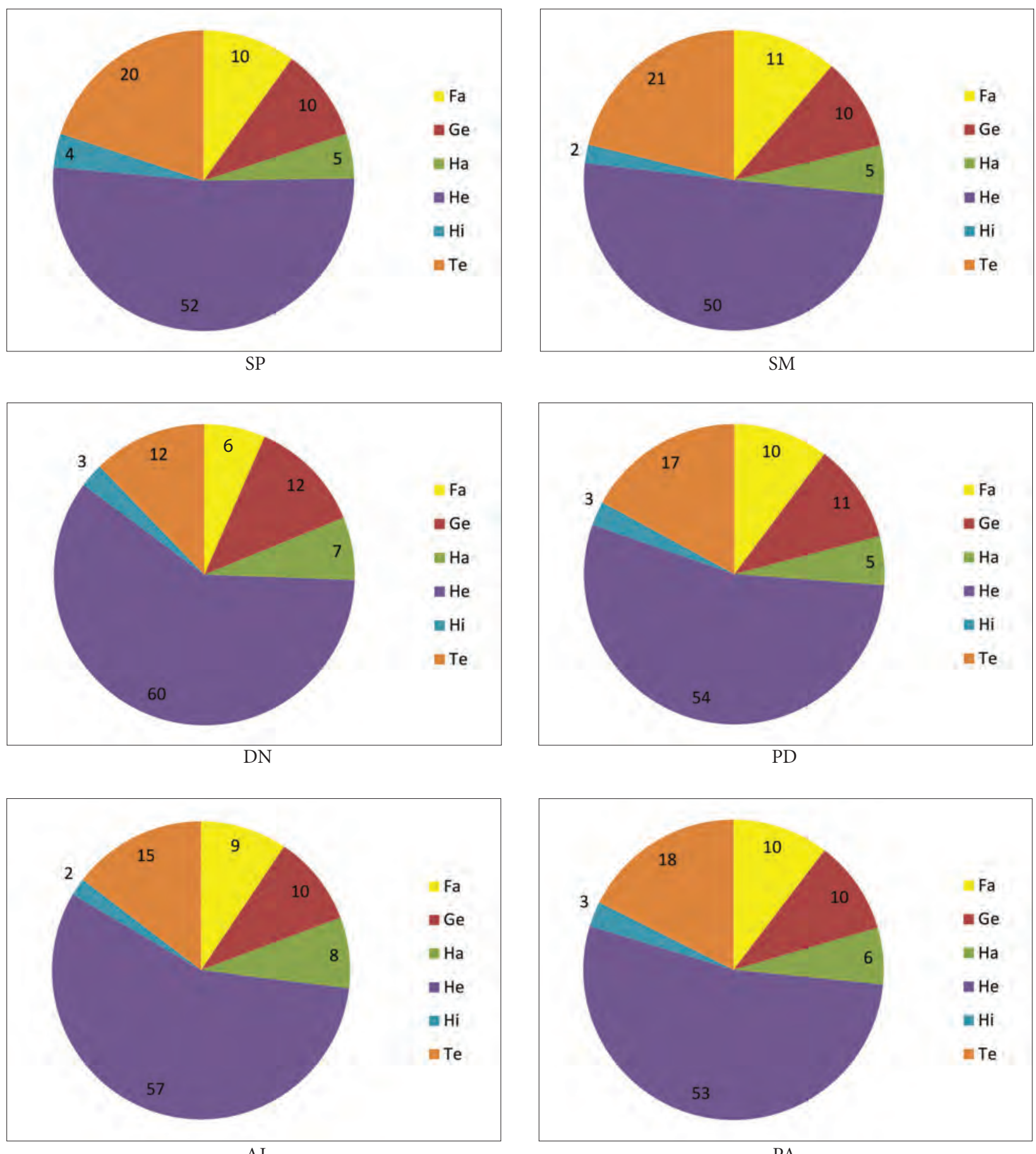

$\mathrm{AL}$

PA

Diagram 1: Percentage share of biological forms in the phytogeographic areas of Slovenia according to M. Wraber (1969). Diagram 1: Odstotni delež bioloških oblik v fitogeografskih območjih Slovenije po M. Wrabru (1969).

Alpine Region / alpsko območje (AL)

pre-Pannonian Region / subpanonsko območje (SP)

pre-Alpine Region / predalpsko območje (PA)

Dinaric Region / dinarsko območje (DN)

pre-Dinaric Region / preddinarsko območje (PD)

sub-Mediterranean Region / submediteransko območje (SM) 


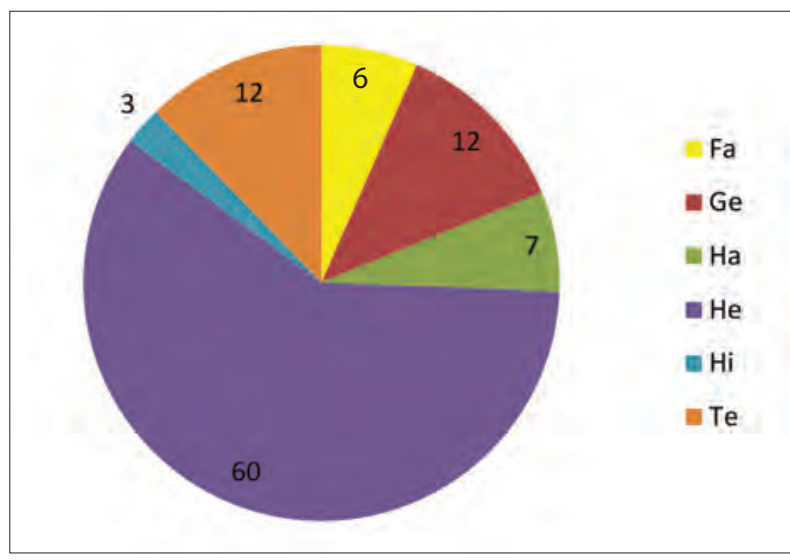

WRABER (1969)

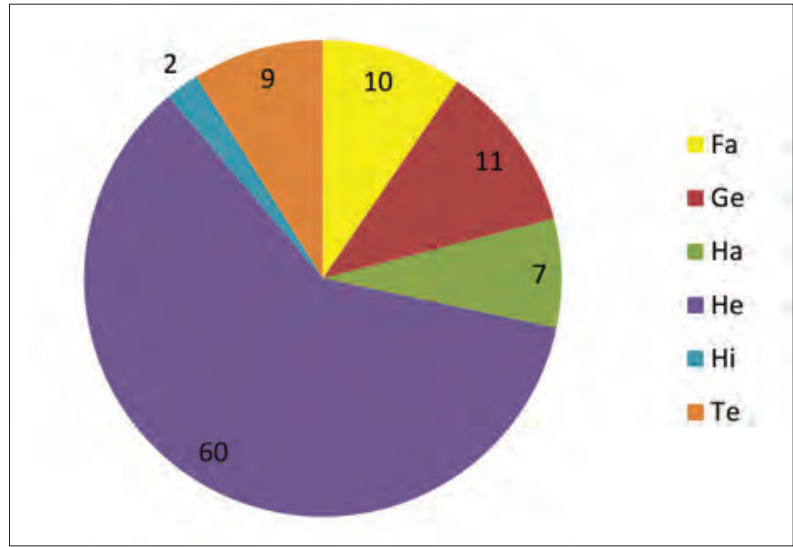

ZUPANČIČ \& al. (1987) DN

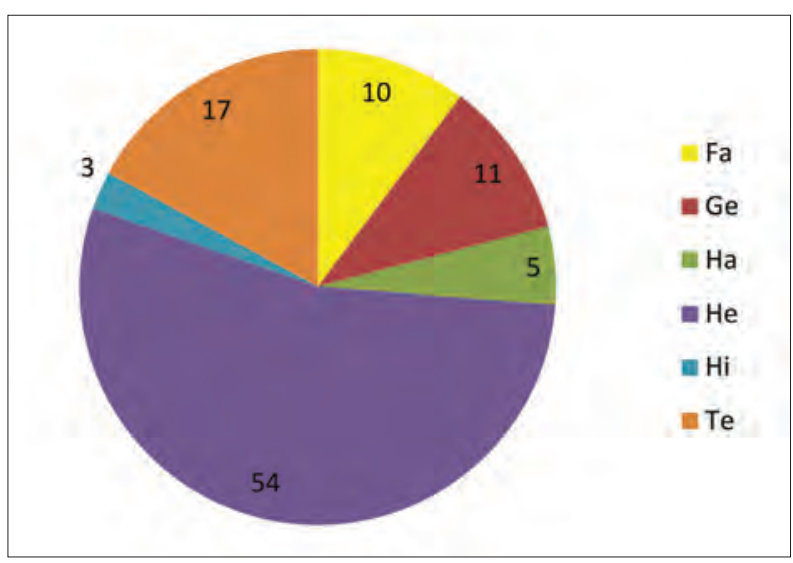

PD

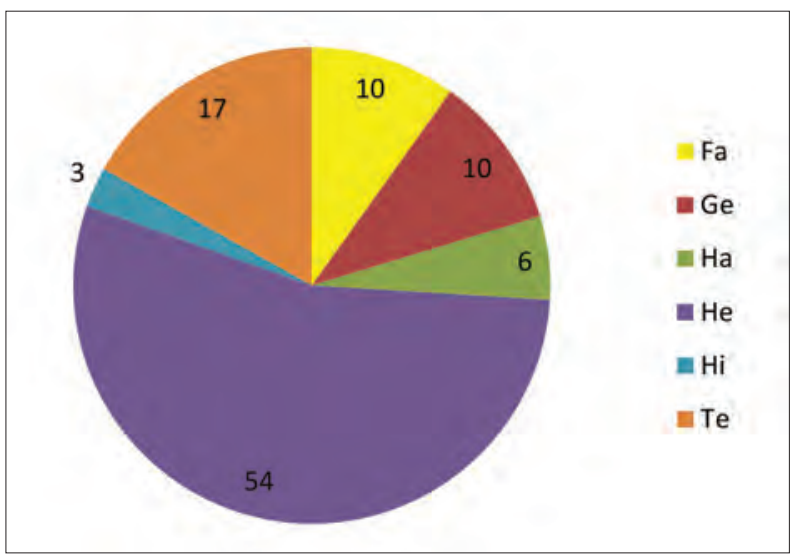

PD

Diagram 2: Comparison of the percentage shares of biological forms in the Dinaric and pre-Dinaric phytogeographic areas in the phytogeographic division according to M. WRABER (1969) and ZUPANČIČ \& al. (1987).

Diagram 2: Primerjava odstotnih deležev bioloških oblik $v$ dinarskem in preddinarskem fitogeografskem območju med fitogeografskima razdelitvama po M. WRABER (1969) in ZUPANČIČ \& al. (1987). 